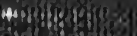

cias

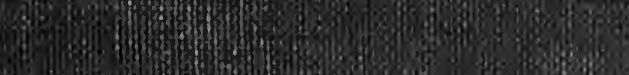
D.

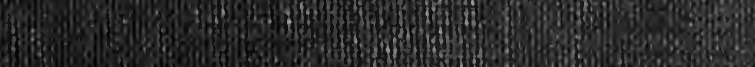
tolo (20. 3. f

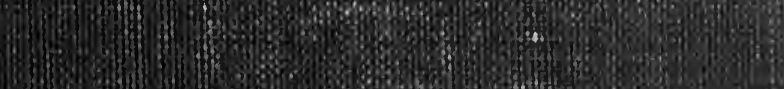
5 5. 43) fon 8.1 In 1.5.

10.5 (3)

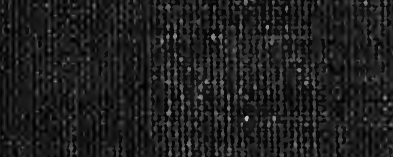

9.

B.

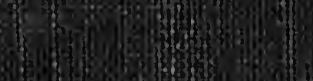

3.

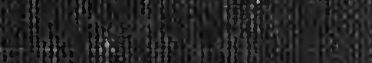

pos 0. 13!-

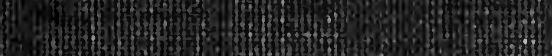




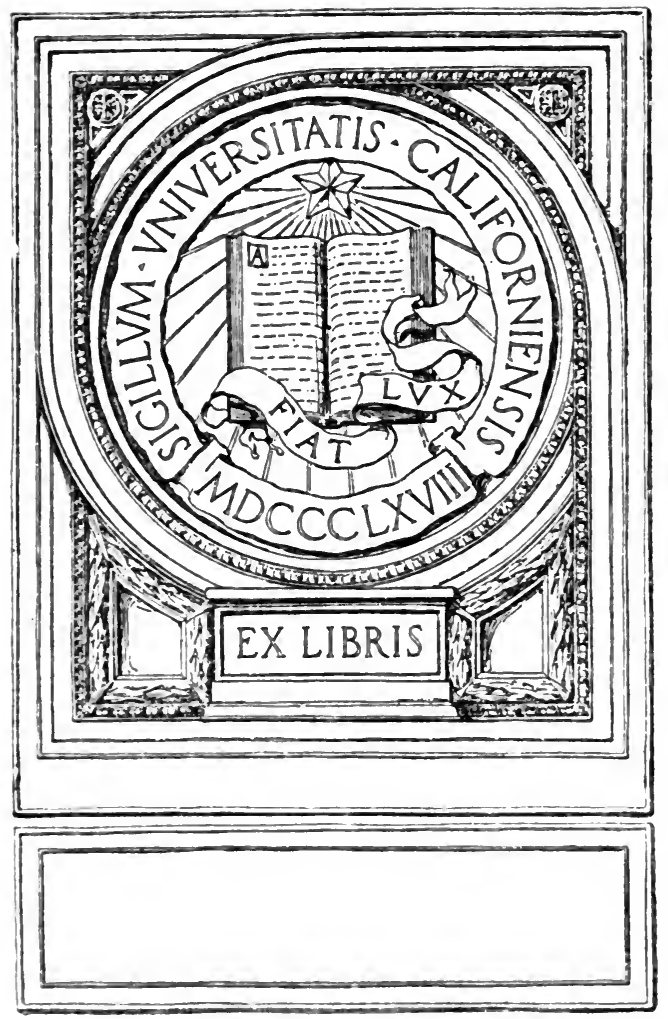




, ,

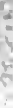

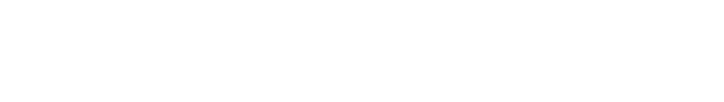



Digitized by the Internet Archive in 2007 with funding from Microsoft Corporation 
STUDIES IN THE PSYCHOLOGY OF

INTEMPERANCE 



\title{
STUDIES IN THE PSYCHOLOGY OF INTEMPERANCE
}

\author{
BY \\ G. E. PARTRIDGE, Ph.D. \\ Author of "An Outline of Individual Study," "The Nervous \\ Life," and "Genetic Philosophy of Education" \\ Formerly Lecturer in Clark University
}

\author{
Hew Work \\ STURGIS \& WALTON \\ COMPANY
}

1912 
Copyright 1912

By STURGIS \& WALTON COMPANY

Set up and electrotyped. Published October, 1912 


\section{PREFACE}

THIs book is an attempt to present, in as untechnical a manner as possible, a psychological view of the nature of intoxication, and of the craving for alcoholic, and to a certain extent of other, stimulants and narcotics. Anyone who considers the problem of intemperance must admit that before we can intelligently cope with the practical questions of control, we must first understand better the human nature that is involved. Whether or not the reader will agree with me that, since the causes of drinking are largely social, the cure and control must also be social, he must admit, I should think, that the point of view here taken in collecting evidence upon the alcohol problem is sound, and that to be prepared to form practical conclusions about temperance and intemperance one must understand the psychological questions involved. That these are both deep and interesting, I hope I may convince the reader.

The work here reported is a continuation of an investigation made some years ago, a part of which was reported upon in the American Journal of Psychology, Vol. XI. Owing to the 


\section{PREFACE}

technical nature of that publication, the views there expressed seem to me not to have had so wide a circulation as I hope they deserve. For this reason the whole matter has been brought up again and re-examined. The main thesis has been expanded and more popularly presented, and practical conclusions have been more fully worked out. Some new experimental matter has been added, and a review made of the literature that has accumulated since the first study was published.

It would be a matter of regret to me if my results were interpreted by anyone as antagonistic to the temperance movement. In this work, if anywhere, there is need of harmonious co-operation on the part of all. In regard to the desired end we all no doubt think much alike. Such differences as there are are differences about ways and means. Let anyone agree with me that the main effort must. be educational and constructive, rather than legal and negative, and there will be, I think, little left to dispute. If I do not place much emphasis upon present total abstinence, it is rather because I think that here is not the firing line of the conflict with alcohol, than that I wish to ignore the dangers of drinking. So far as I know I never met a man whom I thought the worse merely for not drinking. I have met some men, however, whose moral usefulness I thought much 


\section{PREFACE}

lessened by their complete lack of understanding of the inner life of the drinker. We need a revelation of human nature, and a sympathetic interest in the problems and needs of individual men; and we need a clearer perception of the possibility of good that accompanies all great evils. This, it seems to me, is the basis, both of rational optimism, and of sound practical endeavour.

Some of the many obligations to writers and others which I have incurred, I have tried to make plain in the book itself. Very many have helped me whose names I do not know; some who have aided me most I cannot mention at all. In both the earlier and the more recent studies my wife has assisted me in various ways: in gathering materials, and in the troublesome details of revision and proofs. For assistance in the experimental studies of the effects of small doses of alcohol, I am especially indebted to Professor C. F. Hodge of Clark University.

G. E. Partridge.

Worcester, June, 1912. 


$$
w_{103}^{5045}
$$




\title{
CONTENTS
}

\author{
PART I
}

\section{THE INTOXICATION IMPULSE}

CHAPTER PAGE

I The Problem . . . . . . . . . . . . . . 3

II Intoxication and Excitement in Animals . 11

iII Drinking among Primitive and Safage Peo-

PLES . . . . . . . . . . . . . 22

IV Drinking Amovg Civilized Nations . . . . 42

V The Intoxication Motives in Literature and

LANGUAge . . . . . . . . . . . 71

VI Mental and Pirysical Effects of Intoxicants 82

VII The State of Intoxication . . . . . . 100

VIII A Study of Abnormal Cases . . . . . . 133

IX Theories of the Intoxication Impulse . . 164

$\mathrm{X}$ SUMmary of Facts aNd INTERPRetations . . 199

\section{PART II}

THE PRACTICAL PROBLEM

XI The Practical Problem • . • . . . . . 219

XII The Saloon and the Club . . . . . . . . . 222

XIII Preventive and Educational Measures • . 240

XIV The Care, Cure, and Control of the Drunkard 253

XV Summary of Practical Prixciples . . . . 261

REFERENCES . . . . . . . . . . . . 267 



\section{THE INTOXICATION IMPULSE}





\section{STUDIES IN THE PSYCHOLOGY OF INTEMPERANCE}

\section{CHAPTER I}

THE PROBLEM

Our problem is the origin, nature, course of development and the meaning of those traits of human nature and the social life which have led men to use, to enjoy, to become habituated to, and sometimes to be destroyed by, intoxicating drinks. We are well accustomed to incessant outcry against alcohol; we hear much of both the physical and moral disasters resulting from its excessive use; we have statistics dealing with the consumption of alcobolic beverages; there are many excellent investigations of the effects of alcoholic and other intoxicants upon both mental and physical functions; the effects of alcohol in causing weakness and disease in offspring have been carefully studied:- but as yet we have very little insight into the nature of the impulse to use intoxicants, which is so deep-seated and wide-spread among the nations of men; which 


\section{PSTHOTOGYOYOF INTEMPERANCE}

is so intimately connected with so many of our questions of morals, education, government, and the social life; which is the cause, or at least the accompanying condition, of so much misery, poverty, and crime. Our effort has been rather to cure, by the shortest possible course, the most obvious evils of intemperance, than patiently to study the whole problem. This is natural enough, for the evils have seemed pressing, and some palliatives at least ready at hand; while the study of problems is laborious, and too often appears impractical and doubtful of issue.

It is quite natural, too, that our moral attitudes toward such problems as intemperance should sometimes be hastily formed, and uncritical. We all have our standards of moral values, based in part upon natural feelings, and in part acquired from contact with others, and reflecting the ideals of the society in which we happen to be born and live. Such natural judgments and practical wisdom do very well, on the whole, for ordinary affairs. Feeling, social sanction, ordinary observation and interest must be the basis of most of our judgments and actions-must provide the great background of common sense and common, morality by which we live. And yet, in many ways, these native qualities are inadequate to cope with great issues. Until the why of a situation 
is understood fully, the control can never be entirely rational and effective. In all great practical questions, the voice of science is now respectfully heard. It must be so in moral issues. We shall never be fully equipped to pass moral judgments upon the use of alcohol, or to devise means for controlling its use, until we understand more fully why alcohol has played such a part as it has in the history of mankind. Without such insight we shall always be empiricists, like the physician who treats a disease by controlling the symptoms, without trying to understand the nature of the disease.

We do not intend to carry our discussion into the theory of ethics, but simply to point out one truth, and apply it to the study of intemperance. We can never practically grasp any great problem of morality, social economy, and public hygiene until we understand the nature of the human passions which cause such a problem to exist. Were there not something in human nature that made the use of alcohol a persistent and almost irradicable habit in society, we should have no problem of intemperance. We must therefore try to understand what the impulse behind the habit is, what the nature of the effect of alcohol is upon bodily and mental states, that makes the habit possible. 


\section{PSYCHOLOGY OF INTEMPERANCE}

The fundamental question of all is, What is the intoxication impulse, or the craving for alcohol? Why do men indulge in alcoholic drinks? How is this habit related, if it is related, to other traits of human nature? Has it had an origin in normal traits of body or mind, or is it a disease or abnormality? And, if we find it to be a disease, we must still ask what its origin is, what its relations to normal growth are. For a disease is never merely a disease, to be considered by itself. It has a cause. We need to know also the causes of the great variability of the influence of alcohol upon different individuals-why some are safe in its presence, and others are so affected that all moral instincts are swept away before it, and the most fundamental passions of selfpreservation and love of offspring made as nothing. We must know what inner forces in individuals produce the capacity for such powerful habits, and what social factors are concerned in their development and perpetuation.

No one need expect to find all these pressing questions answered as yet by anyone. All we can do at the present time is to lay out certain evidence, follow to their conclusions some wellgrounded principles of human development, construct an hypothesis that shall explain as many of the facts as possible, and perhaps find practical devises that will improve our present 
control of the situation. We do not look for final conclusions.

We wish to know about the nature and origin of the intoxicating impulses. The very fact that these impulses seem so persistent and deepseated, and so difficult to eradicate from society, shows that we must delve deeply into the history of the human mind, if we are to get at the root of the problem. The fact that those who most freely admit the damaging effect of alcohol upon their own bodies and minds are the least able to escape its tyranny shows, in itself, that we are not dealing with any lightly acquired trait of human nature, against which it is sufficient to turn a tide of fashion.

There are many lines of inquiry open to a scientific interest in intemperance. We can gather facts about the use of intoxicants among primitive peoples, and in civilized nations. Something may be learned from the attitude of animals toward intoxicants, and the effects of alcohol upon them. By studying simpler forms of life than our present complex society and individuals, we may be able to detect beginnings, to relate the abnormal to the normal, to find conditions out of which habits of intemperance have sprung.

In order to understand a desire or craving, it is also necessary to know precisely what it is that is craved. We can experiment upon ani- 


\section{PSYCHOLOGY OF INTEMPERANCE}

mals, and even upon the human being, to determine what intoxication, or any effect of alcohol, is. We can measure, test various effects, gather reports of the feelings and thoughts of those we test. We can accumulate evidence from those who have succumbed to habit, and learn the history of their experiences. We can collect statistics about age, social conditions, cures, and the like. Something will be learned from the medical reports of typical and extreme cases of alcoholism. Finally, the intoxication motives may be studied in their expression in literature, language, and art. Drinking songs, the writings of men known to have used intoxicants to excess, the vocabulary of intoxication-all these can in one way or another be regarded as objective evidence of the traits we are trying to study. In fact there are many promising ways of approach to the problem of the nature of the intoxication motives-some already well opened, some as yet quite untried.

The attitude which we wish to take in this study of intemperance, and intoxication generally, is, therefore, that of observation and interpretation of facts-in other words, the scientific attitude. We do not wish to begin with pre-formed moral judgments, for the categories of science are not those of right and wrong. Yet so strong is the tendency to 
evaluate that even sciences that ought to remain purely descriptive are prone to divide everything into two classes, the normal and the abnormal, the good and the badmaking sciences of normal life, and sciences of abnormal life. This tendency to classification has done harm in preventing a study of the abnormal in its normal relations. This is in another form precisely the limitation we complain of in the uncritical in dealing with such problems as intemperance. This attitude always sets up the two rigid classes, the normal and the abnormal, the good and the bad; the former to be fostered and encouraged, and the latter to be suppressed. It is just this practical and easy manner of dealing with human nature, whether instigated by feelings, or by too narrow a science, that prevents a broad and deep understanding of facts in all their relations. So long as the drinking of alcohol, for example, is regarded by great numbers of our population as merely harmful or sinful; a product merely of the evil in man's nature; as ' a result merely of social disease and disorder, we shall never be able to cope with the great evil of intemperance. It is irrational to legislate as though for all time, without knowledge of the nature or the force of the instincts against which the legislation is directed. And how shall we know what to say to the child, or 


\section{PSYCHOLOGY OF INTEMPERANCE}

what interests and faculties to train, in order to prevent his growing up to be a drunkard, unless we know precisely out of what physical and psychical elements the qualities of the drunkard are made? Without the fullest possible understanding of the forces with which we deal, it is quite likely that we shall be looking far away for that which lies near at hand; that we shall lose time and energy trying to do the impossible, or quite as bad, the unnecessary; that we shall cause evils we wish to cure, or put others as bad or worse in their place. 


\section{CHAPTER II}

INTOXICATION AND EXCITEMENT IN ANIMALS

Something may be learned about any human trait, whether of body or mind, by studying its beginning or antecedents in animals. There is no longer need of justifying this approach to human psychology. Genetic methods prevail everywhere, and comparative psychology has become a well-established science. So we may safely start with the assumption that whenever we find a deep-seated trait in the human mind, we shall profit by trying to trace its origins in animal life. Sometimes the trait, in its human form, can be traced but a little way-for example, the conscience-but we can always find primitive traits related to the higher, and in some way involved in producing them. Even religion has in recent years been studied genetically, and its roots found in primitive love and fear: states of mind and habits which in turn have come by an unbroken chain of steps from the most elementary expressions of psychic life.

We might well begin the study of intoxication in an investigation of animal life with three 


\section{PSYCHOLOGY OF INTEMPERANCE}

questions in mind. We should like to know, first, whether animals are affected by stimulants and intoxicants in the same way that men are; and if so how low down in the scale of animal life the physical and mental capacity for intoxication may be found. It would be important, next, to know whether animals acquire the habit of intoxication: whether they enjoy intoxication as men do, and can be said to have a craving for it, or for alcoholic or other intoxicating drinks as such. We should like to know also whether among animals other states may be found, or other impulses, cravings or habits which can throw light upon the nature of the intoxication motive; whether, if animals have intoxication habits of any kind, reason for the enjoyment of such states can be found in their relations to activities that are useful to the animal, and the presence of which we can understand.

Animal psychology has as yet less to offer than we might wish in the way of facts bearing directly upon the intoxication impulse, and these facts are often difficult to interpret,

especially facts about the formation of habit; for, of course, we cannot secure introspective reports of the states of feeling of an animal.

Apparently many animals are affected physically by alcohol in ways essentially like intoxication as we find it in the human species. 
Romanes ( $\left.{ }^{1}\right)$ made experiments upon jellyfish, starfish, and sea-urchins. The first effect upon sarsia, for example, was to cause a great increase in the frequency of the swimming movements: so much that the bell had no time to expand properly between the successive contractions. Gradually the movements grew less and less frequent and forcible, until, finally, the animal was no longer responsive to stimuli applied to its tentacles. Here are, then, the external signs of a series of steps, very like the stages of intoxication in a man. Whether the animal feels in any way as a man does: whether there is a stage of heightened feeling and excitement, followed by depression and a comatose condition, perhaps no one would feel competent to say. It is not at all unlikely. Whether or not the animal is capable of remembering the experience, and desiring its repetition is more difficult still to decide precisely, and yet it is less likely.

There is much evidence to show that the effect of large doses of alcohol upon many species of animals is essentially the same. A period of increased activity is followed by lessened activity.* Insects are capable of becoming intoxi-

* But even upon this point there is not wanting contradictory. evidence. Kesteren (2) made tests upon amœbx by placing the animals in alcoholic solutions ranging in strength from 1 per cent. to 7 per cent. He was not able to detect a stage of stimulation in any case, and found that locomotion 


\section{PSYCHOLOGY OF INTEMPERANCE}

cated. Wasps have been observed apparently intoxicated by the juices of over-ripe fruit. They become excited, and finally crawl away in a semi-somnolent condition, and lie in the grass until they recover, and then return to the fruit. Dogs show quite unmistakably the typical stages of intoxication. Under the influence of large doses of alcohol they become exalted in feeling or, at least, motor activity and expressions of social feeling increase; and following this stage there is one of depression and fear, and the animal skulks away and hides.

Do animals have, or can they acquire, a craving for intoxication or intoxicants as man does? This is difficult to decide. Facts are not wanting, but the interpretation of them is difficult. Stories are often told by reliable writers about elephants, apes, and dogs that have acquired a taste for alcoholic liquors. The fox terrier, a favourite among sailors, is often credited with a craving for alcohol. Hens and chickens will eagerly devour bread soaked in brandy or whisky. Stories are told about dogs that prefer beer to meat, and when offered both together will drink the beer and refuse the meat. All such cases leave much to be desired in the way of psychological interpretation. We do not ceased as soon as the solution reached the animal. Though the animals were able to live in a solution of 5 per cent., there was always some degree of paralysis. 
know whether the animal merely becomes fond of the taste of the drink, or whether the mental state is remembered, and sought once more. There is no doubt that animals can be trained to drink alcoholic beverages, and to like them; but whether a dog, for example, would be capable of forming so complex an association as to seek a drink that is disagreeable to the taste, for the sake of a remote psychic effect, seems doubtful. This is what happens often in the case of man. The mental effect of the drink, and not the drink itself, is what pleases, and as we shall see later, forms the basis of the habit.

On the other side there are numerous facts showing that animals often dislike either the taste or the effect of intoxicants. Darwin $\left({ }^{3}\right)$ relates an instance of baboons being made drunk with beer. The next morning the keeper found them holding their heads tightly, and when offered beer they refused to taste it again. It is too much to assert that they rightly attributed their feelings to their drink the day before, for all the mental action needed is a feeling of nausea at the smell of alcohol. It is quite likely they would have refused food also. Dr. Hodge's dogs, which were experimented upon with alcohol for at least two years, never showed a taste for it, although they had it daily in large doses. One of these dogs, after two 
years' experience with alcohol skulked into a corner and refused to come out again when she scented a bottle of alcohol. In her case the dose had never been sufficient to produce intoxication.

So far as these facts are concerned we have dvidence neither for or against the view that animals are capable of enjoying and seeking intoxication as a man does. It certainly is not impossible that they do. They surely have the expressive signs of enjoyment of the state while it lasts, and if they can form the association between the drink and its effect, and retain a sufficient memory of the state itself as different from their ordinary experiences, they have the mental equipment and degree of intelligence to become drunkards in the real sense. Whether the mental state of intoxication affords for them a sufficiently rich experience to be so retained and sought, may well, however, be matter of doubt; but the difference between man and animals, in these respects, must be one merely of degree and complexity of experience, and not of nature. We cannot suppose the animal capable of the higher motives for intoxication, such as a desire to drown sorrow, or to increase the pleasure of his social relations; but he may not be incapable of obtaining even these effects in some degree from the state when it is once attained. 
We cannot leave the subject of animal intoxication without taking notice of certain states observed among many species of animals, which are very similar to alcoholic intoxication, usually, but not always, connected with the sexual life. These states of exaltation appear to be more common among birds, but are not wanting in mammals. One or two examples will serve to illustrate a phenomenon which occurs in all degrees of intensity, from slight increase in activity to the wildest excitement.

Besides the various plays of animals, in which there appears to be a love of excitement for its own sake, there are in some species marked rhythmically occurring periods of intense excitement. Chapman ( $\left.{ }^{4}\right)$ describes a sky dance of the woodcock as a succession of wild rushes in the air, with always increasing speed and with louder and louder cries, the object of which seems to be to rise to the highest pitch of excitement.

Worth $\left(^{5}\right)$ describes a dance of prairie chickens or sharp-tailed grouse as follows:

"The birds, in companies of from six to twenty individuals, assemble on some hillock or knoll fifty to a hundred feet across, the floor being worn or beaten smooth by years of tramping. After remaining for a time inactive, one of the cocks lowers his head, spreads out his wings nearly horizontally, and his tail perpendicularly, distends his air sacs and erects his feathers, then rushes across the floor, taking the shortest of steps but stamping his feet so hard and so rapidly 


\section{PSYCHOLOGY OF INTEMPERANCE}

that the sound is like that of a kettledrum; and at the same time he utters a kind of bubbling crow which seems to rise from his air sacs, beats the air with his wings and vibrates the air with his tail, so that he produces a loud rustling noise and thus becomes a really astonishing spectacle. Soon after he commences, all the cocks join in, rattling, stamping, drumming, crowing, and dancing furiously; louder and louder the noise, faster and faster the dance becomes, until at last they madly whirl about, leaping over each other in their excitement."

Hudson $\left({ }^{6}\right)$ speaks of the screaming contests of Platan rails, and remarks upon the striking resemblance to the human voice exerted to its utmost pitch and expressive of extreme terror and despair. Wallace says:

"We see that the inferior animals, when the conditions of life are favourable, are subject to periodic fits of gladness affecting them powerfully and standing out in vivid contrast to their ordinary temper. Birds are more subject to this universal joyous instinct than mammals, and there are times when some species are overflowing with it."

Groos ( $\left.{ }^{\tau}\right)$ also speaks of these strange characteristics of the love dances and the play of animals, and explains the intense excitement of some of them on the ground that it is necessary that the sexual impulse acquire tremendous power and its fulfilment be rendered difficult-hence the great and long-continued excitement preceding the act of pairing.

Such facts suggest at the very outset many 
problems; and although they cannot be probed deeply at this point, one or two principles of development may be mentioned, which will later assist in understanding them.

We can assert, first, that whenever a habit or capacity for a particular form of behaviour is found to be deep-seated and widespread, whether in animal or in man, it has a practical meaning. This we find to be true of all play and other seemingly purposeless activities. And we should expect to discover, on this principle, that all states of extreme pleasure and excitement-such as intoxication-and the capacity to attain them, would not prove to be exceptions. We cannot readily believe that they are mere chance phenomena, without meaning, but should expect to discover in them a deep origin and close connection with the practical life of the species.

Now, whenever we try to trace back the higher emotions of man to their beginnings, we usually find them connected with one or both of two fundamental modes of behaviour, having for ends the preservation of the life of the individual, and the continuance of the race by reproduction. To carry on these activities many structures, functions and impulses have been established, and these fundamental structures and modes of action underlie all later developments. From them are created forms 


\section{PSYCHOLOGY OF INTEMPERANCE}

and functions sometimes seemingly very remote in their purpose and mechanism from the primitive mechanisms from which they are produced. Often old structures and habits remain latent in the organism, and are only in unusual circumstances utilised by being taken up into higher functions.

We are justified in assuming, with a high degree of probability, that in all exceptional traits of consciousness, such as intense excitement and intoxication, and the craving for these states, old pleasure and pain mechanisms, once connected with the practical life, are at work; and that these states are somehow connected with the mode of development of the individual or the progress of the race as a whole.

Such a conclusion is not based upon precise evidence in regard to any one function, and is not to be taken as demonstrated truth; but the testimony in its favor is so corroborative, part to part, and this view now clarifies so many problems of the emotional life of man, that it must be accepted as at least a co-ordinating point of view from which such problems as intoxication may be investigated. We do not know precisely to what extent either the reproductive or other functions are involved in the history of the intoxication pleasures and impulses; but we shall see that it is difficult to avoid the conclusion that they are concerned in them, and it 


\section{INTOXICATION IN ANIMALS}

\section{1}

is because of the connection of these states with practical functions, that they have been preserved by selection, and that impulses to seek such states of intensity have been established, still further securing them. All this, however, is at this point merely suggested as an illuminating hypothesis, on the basis of which the problems of intemperance in man may be studied. 


\section{CHAPTER III}

DRINKING AMONG PRIMITIVE AND SAVAGE PEOPLES

WE can now see the full scope of the genetic method of approach to our problem. Carried out completely, it would be nothing less than a study of the genesis of all the intoxication motives throughout the whole racial history from the earliest animal life to the present time. It would include the examination of both physical and mental data, and their relations to one another. It would go still further. It would study, in the individual, the function of the intoxication states and impulses, tracing these from infancy upwards-and finally it would try to correlate the two series of facts, the racial and the individual.

In the study of the habits of primitive and savage peoples we should expect to find much valuable material for studying the nature of the intoxication motive. Now we shall begin to find data which are more psychological in nature. The evidence is still not introspective, but even the most primitive man has expressed himself in symbols which we can interpret psy: chologically with great confidence. We cannot, 
it is true, reason directly from the savage to civilised man; but the explanatory power of facts about mere simple civilisations, in interpreting the later and more complex, is now so widely recognised that we can pass without further argument to a review of the facts.

To present adequately the known facts about the drinking habits of lower races, and the whole history of the use of stimulants and narcotics of all kinds, would require many volumes. The purpose here is not to give such a detailed history of drink, nor even to name and classify the great number of intoxicants in use in the world; but, if possible, to extract from sufficient samples of the data psychological principles, which will aid in interpreting the intoxication motive as it appears in present social life.

The custom of using intoxicating drinks is certainly polygenetic; that is, it has not spread as a habit from one part of the world to another, but is indigenous in many places, and has prob-l ably arisen afresh at many times. No one can examine the data without being convinced that, whether for good or evil, intoxication has played a very important part among uncivilised peoples. Alcohol has not been simply a beverage, causing (accidentally) intoxication; it has been a great factor in the mental life of peoples, intimately connected with religious, social, intel- 


\section{PSYCHOLOGY OF INTEMPERANCE}

lectual and practical activities. It is difficult for us, who have so many interests and means of mental excitement, to understand, precisely, how the savage has looked upon intoxication, and the uses to which he has put it. After a study of the facts it will be quite as difficult to understand what the religious and social consciousness of the savage might have been without the intoxication cults. Intoxicants have been literally the creators of gods, and about their use have crystallised myth and superstition, rite and ceremony, in endless variety. State ceremonials, worship, marriage, funerals, secular festivals, initiatory rites, dances, hospitality (both public and private), care of the sick, preparation for war, consummation of peace, transaction of business-all have served as occasions for intoxication, and have been influenced by the use of intoxicants.

The relation of intoxication to religion is an interesting and fruitful psychological theme. Excitement, whether induced by intoxicants or otherwise, has often been regarded as the essential part of religious feeling. It has been induced in various ways as a means of divine worship: by violent movement, fasting, selftorture, and by drugs. Epilepsy, chorea, and other neurotic conditions have been, and still are, regarded as divine, and have been voluntarily sought. Long courses of training in 
practices that make the nerves crepitate have been indulged in in order to bring the soul into touch with supernatural powers. So it is but a single instance of a general attitude toward things divine, when intoxication is regarded as god-given or pleasing to the gods. To uncivilised man this belief is entirely logical; not only did the ecstatic feeling and sense of increased power induced by the intoxicant suggest this view, but in the dreams which drugs produced the savage seemed to enter his heaven and to talk with his gods. Thus we need not be surprised at finding that the belief in the religious nature of intoxication was widespread, almost as nearly universal as the use of intoxicants, that the cult of intoxication has occurred in many forms, and that remnants of it can still be found, like rudimentary organs, in our own religion. It is a long way from the ancient soma worship, in which all the devotees of Indra became intoxicated to please the god, to our own solemn sacrament of the communion, yet none of the transitional steps are lacking; and psychologically at least this sacrament must be supposed to have a deep ancestral root in primitive intoxication rites.

Indications of the use of intoxicants by primitive man for some purpose, probably religious, are not wanting. Dawkins, $\left({ }^{8}\right)$ speaking of the neolithic stage of civilisation in Europe, says 
that the poppy was cultivated, and that small round cakes have been found, indicating a probable use as an intoxicant. The earliest historical example of a religious cult certainly founded upon intoxication is the soma worship of the Hindus. In this belief, the god Indra was supposed to be present in the wine; just as, at a later time, the Greeks believed in regard to Dionysus. Both the Zend Avesta and the Vedas speak of a sacred plant, the fermented juice of which was employed in sacred rites. The Hindus believed that performance of the soma rite was highly beneficial to both body and soul; indeed they believed that Indra himself drank soma to obtain strength and victory in battle. Length of days was also attributed by them to its use.

Religious cults of intoxication are scattered all over the world among uncivilised peoples, and there can be little doubt of their independent origin at many times and in many places. A few, of many, will be mentioned.

A few years ago a remarkable religious intoxication ceremony was described, then newly discovered among American tribes of Indians. It spread from the Kiawi Indians and associated tribes, which formerly ranged from the Arkansas River southward into Mexico, until it became the chief religious practice of all the tribes on the southern plains. The ceremony, 


\section{PRIMITIVE PEOPLE'S DRINKING 27}

as described by Prentiss and Morgan, ( $\left.{ }^{9}\right)$ usually takes place on Saturday night and lasts until noon of the next day. The men sit about the brightly burning camp fire, chewing the intoxicating mescal, while a continuous singing and beating of drums is kept up, interrupted by occasional prayers for the sick and by baptismal rites. The mescal button, in this rite, symbolises the sun as the giver of life, and the purpose of the ceremony is to enable the devotees to understand the mysteries of the universe.

The Pueblos, another race of American Indians, are described as a sober people, who never become intoxicated except in their religious ceremonies. Featherman $\left({ }^{10}\right)$ describes a sacred festival of the Yakuts which is nothing more than an elaborate drinking ceremony. Spencer ( ${ }^{11}$ ) says that the Dahomans deem it a duty to the gods to be drunk. The Ainos of Japan drink to the gods, as is also the custom of the Polynesians. In Fiji, drinking is accompanied by prayers or chants to the gods. The Patagonians pray to be eternally drunk in heaven. Among the American Indians intoxication by tobacco was put to religious uses.

Shamanism, which can be said to be the first organised religion, and which spread all over the world, is founded upon intoxication. Shamanism is essentially the belief that all events are caused by mind-by good and evil spirits. The 
shaman is a priest, whose function is to control these spirits by putting himself into touch with them. He does this by excitement; by inducing a mental state in which he sees visions, prophecies, and professes to drive out evil influences and diseases. The shaman uses various means of attaining his divine frenzy. Epileptic or hysterical excitement is produced by wild and rapid movements, by contortions, by beating of drums, by fasting, and by drugs. In some cases a long training is undergone to produce a nervous condition. Young candidates are chosen from among the constitutionally nervous, sensitive, and excitable. The use of intoxicants to aid in producing the divine state is very widespread, and the method is practised both by male and by female shamans. Sometimes the intoxication is participated in by onlookers as well as by the priest. An interesting instance has been described by observers in the Philippines. ${ }^{12}$ ) In some of the native tribes the shaman is usually a woman, who works herself up to a state of frenzied nervous excitement by contortions and by drinking great quantities of fermented liquor. Accompanying her medicine ceremonies there is feasting and revelling, until all present become intoxicated and fall into an unconscious state.

Many other instances could be cited. The Indians of California, Mexico, Peru and Brazil all 
had drug ceremonies which vary in the drug used, and in minor matters of form, but all of which are essentially alike in their purpose. Dyer $\left({ }^{13}\right)$ says that the Darien Indians of South America give seeds of the intoxicating datura to children to produce a prophetic delirium in which they reveal hidden treasures. Information about their enemies was obtained in a similar way among other tribes.

Intoxication and excitement as religious ecstasy do not by any means end with the shamanistic stage of religious development. One cannot fail to see that their descendants have survived during all stages of culture, even our own. Various forms of nervous disorder, such as hysteria, epilepsy, chorea, convulsions, and ecstasies have been induced voluntarily for religious purposes-and hardly a year passes in our own century in which we do not hear of a new practice founded upon some form of excitement.

The use of intoxicants for religious purposes, established, as it were, their standing among primitive customs. The state of intoxication, instead of being regarded as immoral or in bad taste, as among us, was highly commendable and correct on many occasions. We can truly say that there is no important event in life that has not been habitually celebrated by intoxi- cation. Every occasion that excites the emo- 


\section{PSYCHOLOGY OF INTEMPERANCE}

tions, whether of joy or sorrow, seems to have demanded somewhere artificial means of intensifying the feeling.

Among some New Mexican Indian tribes a peculiar birth ceremony has been witnessed, celebrated only at the birth of a first child. In this, the father becomes intoxicated, and while in this state, is surrounded by a dancing multitude who score his body until the blood flows.

The use of intoxicants in pubertal rites is very common, and was often practised by American Indians. The Tuscaroras ( $\left.{ }^{14}\right)$ of North Carolina, in their initiation rites, administered to the boys several kinds of bark and stimulating plants which produced a state of intoxication. When the Creek $\left({ }^{15}\right)$ boys were to be initiated into manbood they gathered two handfuls of a certain plant which intoxicates and maddens, continued eating the bitter root for a whole day, and then steeped the leaves in water and drank from the decoction.

Marriage among uncivilised peoples has al; most universally been a time of feasting and drinking, in which intoxication adds to the pleasure and excitement. In many places it is celebrated by special ceremonies in which drinking forms a part, sometimes in causing intoxication, sometimes in other ways.

Even death has been celebrated by intoxif cation. Featherman $\left({ }^{18}\right)$ reports of the Lapps 
that when a man is dying his friends gather about the bed to assist the passage of the soul into the next world; and in order to produce an artificial excitement, and to make them weep, they drink freely of brandy. Funerals often close in general intoxication. Among the Urabas of Nicaragua, ( $\left.{ }^{17}\right)$ when a chief dies, ceremonies are held around the grave for two days, carried on amid the excitement produced by intoxicants. Among other tribes the dead are honored and remembered by annual drinking festivals.

In a more general way, aside from special celebration and occasion, drinking and other ways of inducing intoxication have been intimately connected with the social life of primitive and savage peoples. In many times, places, and ways intoxicants have been used to stimulate or create social feeling. Besides this, many social ceremonies have been described in which the use of the intoxicant appears to be the main function. We can say, indeed, that among uncivilised peoples every event in the community out of the daily routine, which brings people together socially is likely to be the occasion of intoxication.

The American Indians furnish an example of the close connection of stimulants and narcotics with the social consciousness. Although alco- 
holic drinks were used among many tribes on the North American continent, the great intoxicant was tobacco; it was used not only for its soothing effect, but very frequently to cause violent intoxication. Its influence upon the thought and social activities of these peoples was very great. Abbott ( ${ }^{18}$ ) says: "To know the history of tobacco, of the customs of smoking and the origin of the pipe, would be to solve many of the most interesting problems of American ethnology. Among the Wabanaki, the eastern branch of the Algonquins, the god Glooscap, who is said to be the most Aryan-like divinity not created by an Aryan people, was believed to be a great smoker of tobacco. $\mathrm{He}$ entered into smoking contests with giants, who were his enemies, and put them to rout, much as our Saxon forebears used to drink one another under the table."

Among some peoples drinking ceremonies have taken on the importance of state functions. A very interesting example is that of the Seminoles $\left({ }^{19}\right)$ who indulged in a slightly intoxicating drink known as the black drink. This was prepared in the public square for the whole community, by a cook expressly charged with the duty. The taking of the black drink was regarded as a solemn act, having both a religious and a military significance. Extraordinary powers were attributed to it. It was sup- 


\section{PRIMITIVE PEOPLE'S DRINKING 33}

posed to have a purifying effect upon the lives of the people, and to efface from their minds all the wrongs they had unintentionally committed. It had the power of imparting courage to the warrior, and of rendering him invincible; of binding ties of friendship, and of exciting kindly feelings. They regarded it as a blessing bestowed upon them as a chosen people.

A similar ceremony was performed by the inhabitants of the Tongas $\left({ }^{20}\right)$. When they arose at break of day, the higher classes met for a drinking bout. The taking of kava was always attended with tedious ceremonial and the strictest observance of etiquette. The whole community assembled, but the common people participated only as spectators. A kava party was regarded as an essential part of any state affair. Among the Creeks (21) too the taking of their war physic was of the nature of a state ceremonial.

Much of this evidence points to the conclusion that drinking among all primitive peoples was religious and social in its origin, and that it was an act having significance. The use of intoxicants as a beverage was for the most part not practised among them, nor even understood. The drinking of the savage naturally and typically takes the form of occasional excess, with longer or shorter periods of total abstinence. The statement is often met that 


\section{PSYCHOLOGY OF INTEMPERANCE}

tribes, usually sober and industrious, on occasion indulge to great excess.

Numerous examples could be quoted. Among the Guatamalans, ${ }^{22}$ ) reunions and dancing are the most common forms of amusement. These occur periodically, drinking is inseparable from them, and the invariable result is that all without exception become helplessly drunk. At other times they lead sober and commonplace lives. The Dyaks of Borneo $\left({ }^{23}\right)$ celebrate numerous festivals of a quasi-religious character. The head feast lasts four days and four nights, and a general state of intoxication closes the solemn ceremony. Some tribes of the Pueblos $\left({ }^{24}\right)$ indulge once each year in a drinking bout which continues from one to two weeks. On these occasions they take the wise precaution of drinking in relays, one third of the men drinking at a time, while the others remain sober to care for their comrades, and to prevent them injuring one another, or being attacked by other tribes. Some of the dances of the Pueblos end with bacchanalia in which not only general intoxication but other excesses are allowed. Other tribes, for example the Keres, $\left({ }^{25}\right)$ have the annual drink festival. They, like the Pueblos, allow themselves unlimited license, become intoxicated, and give free rein to all their impulses. The Mosquitos $\left({ }^{26}\right)$ have drinking bouts which last for 
four days. Large numbers come together and drain a canoeful of liquor which has been prepared for the occasion. Sometimes the people of surrounding villages are invited, and a drinking bout is held, first in one house, and then in another, until a climax is reached in a general debauch in which both sexes take part. The Gonds ( ${ }^{27}$ ) of the central provinces of Hindustan believe that on occasion they have divine permission to sing, laugh, and drink according to their hearts' content, and they use this privilege by becoming at times intoxicated and giving way to unrestrained indulgence, squandering all they may have earned in a long time of sober industry. Other cases might be cited in profusion, but these will suffice to show a characteristic trait of the savage's drinking.

The question arises whether the use of intoxicants is universal among uncivilised peoples. The statement has often been made that no tribe has ever existed that has not had its stimulant or narcotic, but this cannot be substantiated. It is true, however, that there is no large area of the earth's surface without its indigenous intoxicant. E. H. Man $\left({ }^{28}\right)$ says that in the Bay of Bengal, prior to the advent of the whites, the natives were ignorant of any form of intoxicant. The Fuegians are said to have no intoxicating drinks of any kind, using 


\section{PSYCHOLOGY OF INTEMPERANCE}

nothing but water. Several nations of American Indians, among them the Hurons, Chinooks, California Indians, the Shoshones, the Natchez and the Seminoles are all credited either by Bancroft or Featherman with an ignorance of alcohol in any form, though, like other tribes, they probably used tobacco to produce intoxication. Some tribes of Indians in New Granada, South America, are said not only to have no intoxicant of their own, but to refuse persistently the drinks of the whites. But these are decidedly the exceptions. Almost everywhere will be found some intoxicant.

Although uncivilised man cannot be said to be entirely devoid of ideals of temperance or perhaps even of abstinence, temperance, morally enjoined, seems to be on the whole foreign to the savage's habit of thought. We find, rather, that intoxication is of ten commanded by religious laws, or prescribed by social custom to all. Spencer thinks that temperance arose as self-control in order to offer libations to the gods. Such facts as those we have just been reviewing indicate that regulation of drinking was at least connected with religious ritual and social etiquette. Whatever is enjoined must be regulated, and the more important a function becomes, the more likely is it to be hedged about by laws and custom. Laws regulating drinking among lower classes, prohibition 
of drinking to women and to children, may well have taken rise in the belief in the divine origin of intoxication. Doubtless other motives entered. There was more temperance among women than among men, because their activities were less exciting and more regular; and because, too, of deep psychical differences. Obvious physical ills from excessive drinking must also have played a considerable part in enforcing abstinence. Whatever decreased capacity for warfare, or increased dangers from atțack, must of necessity have been regulated by custom. Thus moral attitudes towards drink may have crept in, self-control appearing virtuous at first for practical reasons long before it was recognised as an ideal or was mativated by inner demands.

The habits and temperament of uncivilised peoples illustrate further the fact, discovered in studying phenomena of intoxication among animals, that the impulse to seek states of abandonment is very deep-seated, and that it is expressed in many other ways than in intoxication by drugs. The main characteristic of all these phenomena is the desire to reach a moment of complete abandonment, and to carry on excitement to a culmination in which the physical powers break down and are exhausted. 
This moment is induced in so many ways, and it appears to be so marked a quality of developing minds and bodies that we must suppose it has some significance. The culmination of action in intense mental excitement is so frequently observed among savages, and is, in fact, so customary and natural a result of all their social activity that we may say, in general, that whenever excitement of any kind begins, in the activities of the savage, it tends to be carried higher and higher, until the body can bear no more and breaks down under the strain.

Dancing best of all illustrates this trait of savage life. Dancing and intoxication may occur at almost any public event among savages -as marriages, funerals, games-in fact at any social function. The more unusual or state occasions are often times of throwing off all control, and giving the mind over to the effects of violent movement, sexual excitement, intoxication by drugs, and to general abandon. Intoxicants may or may not be used to induce these states. Scourging of the body, games of torture, pain of any kind, fantastic sights, hideous sounds, as well as violent movements, all serve the same purpose. Public festivals which begin with much dignity often degenerate into scenes of wild disorder before they are finished. The great war dance of the Tupis, $\left({ }^{20}\right)$ 
a description of which happens to be at hand will illustrate this. In this dance the people arranged themselves in groups, and at a well-understood signal each group began to sing, at first in a low tone, or humming, which was continued for a long time with an ever-increasing sound, until it terminated in dreadful yells and hideous howls. As the sound increased, the jumping became more violent, until the effort was finally so furious that many would fall to the ground unconscious. Three or four sorcerers stood in the centre, shook the tamarack, and blew tobacco smoke from cane pipes upon the dancers.

Mrs. French-Sheldon, $\left({ }^{30}\right)$ in writing of the customs of the natives of East Africa, gives an interesting account of dances in which the desire for excitement is carried to a great excess. She says,

"The young fellows will collect in groups and dance as though in competition; they dance with their knees rigid, jumping into the air until their excitement becomes very great and their energy almost spasmodic, leaving the ground frequently three feet as they jump into the air. 'At some of their festivals this dancing is carried to such an extent that I have seen a young fellow's muscles quiver from head to foot! and his jaws tremble without any apparent ability on his part to control them, until, foaming at the mouth and his cyes rolling, he falls in a paroxysm upon the ground to be carried off by his companions. This method of seeking artificial physical excitement bears a singular resemblance to the dances of other nations outside of Africa." 


\section{PSYCHOLOGY OF INTEMPERANCE}

Examples of this trait of savage life and, to a lesser extent, of civilised life, could be multiplied to almost any extent. The literature of games, plays, and dancing abounds in material which a complete study of this most interesting phase of the psychology of intoxication would need to take into full account.

An interesting comparison might be made of the intoxication habits of the savage and of the child. Love of excitement, and the voluntary seeking of the moment of abandonment is a marked characteristic of childhood. Indeed we may say that love of intense excitement for its own sake is a normal trait of play. That such impulses are not merely the result of an overflow of energy, but that they are inspired by deep instincts, or are caused by profound effects of activity upon the body, is shown by the fact that the fatigued child, and the child defective in energy, are often quite as susceptible to these states as the strong child. Even in young infants the tendency toward cumulative excitement and crisis may be observed, as in the caressing movements, which often begin softly and end in a paroxysm of excitement, with striking and other violent movements and muscular convulsion. Craving for strong sensation, for violent laughter, rapid movement, whirling and dancing, the craving 


\section{PRIMITIVE PEOPLE'S DRINKING 41}

for ecstatic states of feeling-all these indicate a natural tendency on the part of the young to seek exalted or erethic states of the nervous system which, both in their motives and in their expression, much resemble the phenomena of intoxication produced by drugs. At puberty both the capacity and craving for states of intensity are greatly increased. All the intoxication motives then become active to such a degree that we may say that the whole period is characterised, more than by anything else, by the love of intoxication $\left({ }^{31}\right)$. 


\section{CHAPTER IV}

\section{DRINKING AMONG CIVILISED NATIONS}

THE purely historical aspects of drinking among civilised peoples have been well treated by several writers. The best account will be found in Samuelson's History of Drink, and the reader interested in the details of this story will find there much of value. The present interest is not in this narrative as such, but in certain conclusions that may be derived from the historians, which throw light upon the psychological problem that lies before us.

Samuelson says that in every nation there has been a period just preceding the time of highest culture, when intoxication was prevalent; and that again, after the highest point of culture had been passed, a second period of intemperance always ensued. In China, it seems, there was an early period of gross intemperance. Mensius, a disciple of Confucius (about 500 B. C.) deplored the drunkenness of his day, and the excessive use of wine in the sacrifices; and speaks as though he thought the nation was returning to a former state of excess. And in fact it is known that long be- 


\section{CIVILISED NATIONS' DRINKING 43}

fore the time of Mensius, drunkenness was very prevalent in China. The Shooking or History, and the Sheeking, or Book of Ancient Poetry speak of an edict against drunkenness said to have been promulgated about $1100 \mathrm{~B}$. C. It appears that at about that time drunkenness had gained such a hold upon the people as, in the fears of some, to threaten the life of the nation. In India also there was an early period in which intemperance was widespread among the people. The soma and the sura, both intoxicating drinks, were freely used, and as we have seen, the former plays an important part in the religion of the nation. Its use was not in the beginning looked upon with disfavour, but allowed and sanctioned in the belief that Indra himself could do no great deed unless he were intoxicated. In both these nations it appeared that a long period of temperance has gradually been followed by addiction to the use of narcotics. Throughout all these eastern countries opium has become a curse. This is not an accident nor a coincidence, but a natural outcome, we shall see, of a decadent or stagnant national spirit; of the widespread pessimism, which appears not only in religion, but in all interests when nations have passed their growth period and have entered upon a decline, or upon a long period of stagnation.

Among the western nations Greece furnishes, 


\section{PSYCHOLOGY OF INTEMPERANCE}

in the worship of Dionysus, the best example of a religious cult growing out of the intoxication impulse. The Dionysiac cults represent the national spirit of Greece in the time preceding the period of greatest culture. In its earliest form, the Dionysiac worship appears to have been merely dancing and singing about the altar of the god, accompanied by intoxication, but with all the revelry there was an air of solemnity and reverence. This cult, however, spread far beyond these confines of a religious ceremonial, and to a certain extent was associated with practices which undoubtedly had their origin in the sexual life. Here sex, religion, and intoxication were combined in an undifferentiated feeling. The spirit was one of abandonment. At the periods of the bacchanalia slaves were allowed a brief time of liberty, and general drunkenness prevailed. Bacchus was represented in human form. Women frenzied by drink or excitement carried cymbals, dancing and singing songs in honour of the god. In one of the performances in which the mænades, who were women and girls, took part, orgies were held at night in the mountains; there were blazing torches, and the wildest excitement prevailed.

The cult and symbolism of Dionysus have been much discussed and variously interpreted. Nietzsche $\left({ }^{32}\right)$ says that the Greek conception 
of Dionysus was an expression of the fundamental Greek instinct. In it the Greeks found or felt the revelation of the mystery of life, and by it they expressed the triumphant affirmation of life over death and change. Nietzsche finds also in the Dionysiac cult an instance of th very close relationship between sex and intoxif cation.

Taylor ( ${ }^{33}$ ) approaches an explanation of the Bacchic and Eleusinian mysteries of the Greeks from the side of their symbolism. He says,

"They were considered for two thousand years or more the appointed means of regeneration through an interior union with the divine essence. They were symbolic of the death of the old life, and the birth of the new. The lesser mysteries occultly signified the miseries of the soul while in subjection to the body; the greater obscurely intimated by mystic and splendid visions the felicity of the soul here and hereafter when elevated to the realities of intellectual vision."

Whether or not such explanations of the form of these rites are adequate, there is no doubt that the symbolism and the practices are both based upon deep emotional traits in the Greek life. They represented the spirit of the times or, as Nietzsche expresses it, a fundamental instinct in the Greek life. This was an age of abounding vitality and enthusiasm which was about to burst forth into exalted art and thought, and was first expressed in this crude way. Music, the dance, intoxication, revelry, all united here under the guise of religious 


\section{PSYCHOLOGY OF INTEMPERANCE}

fervour to express the natural exuberance of if life which was characteristic of this civilisation. It was the spirit of youth and life which could not yet be controlled, nor organised nor directed into productive and conventional forms, but was exercising itself in dramatic representation and crude symbolism. Perhaps at no other time in history has the inner growth force been so exemplified and so fervently worshipped as in the early period of Greek history. The spirit of intoxication, as it was expressed in the Dionysiac cult, was one form in which this force found vent in consciousness. The feeling which it expressed, it has been well said, is the craving for "life and for life more abundant."

The poetry of this period puts clearly before us the deep feeling element of the intoxication impulse. Farnell $\left({ }^{34}\right)$ says that the dithyramb began here in the wild ecstatic song sung by wine-flushed revellers. Mure ( ${ }^{35}$ ) expresses the same view when he says that everything leads to the belief that the character of the Bacchic dithyramb, especially as remodelled by Arion, was like that of the god and his worshippers, an exuberance of jovial excitement. Nietzsche discovers here too the origin of Greek art, at least in one of its motives. One element of it, he maintained, originated in the phenomenon of intoxication associated with 
Dionysus; the other in the phenomenon of dreaming which he associates with Apollo. Greek tragedy is the outcome of Dionysiac music fertilised by Apollonic imagery. Thus, in one of its expressions, we can see how, if these interpretations of Greek life are correct, the intoxication impulse, originating in instinct, becomes refined and ends in intellectual expression. It is emotional force, controlled and organised to serve the ends of consciously felt ideals, that constitutes the higher Greek culture. The crude motives are taken up into the new life; the lower enthusiasms are transformed, and become the high ideal which is the necessary condition of creative work $\left({ }^{36}\right)$.

A second period in Greek history can be discerned in which intoxication motives played a part. As ideals became military, and culture declined, dissipation followed, but with new motives. There is no longer in the later period the religious fervour, and the glow of youthful exuberance of feeling; but the excitement of conquest, new and foreign ideals, love of wealth, craving to resuscitate exhausted feeling, fatigue, and finally all the ills of the decrepit and declining civilisation which was merged into the Roman.

Other developmental periods were marked by traits similar to those we have found in Greece and elsewhere. Especially is this true of the 
early decades of the Renaissance. The vice of intemperance was then again threatening, and in a sense it was the keynote of the whole movement. It was a time of intemperance in many forms, and the excessive use of alcohol is but one expression of a movement which culminated finally in an intellectual and moral awakening of all Europe. In Italy, especially, the intoxication motive can be observed stirring all departments of life. All students of the time seem to be agreed in admitting that it was a day of extreme sensuality. It was a time of love of display and dramatic effect, of great feasts, and great civic processions. Especially the carnivals in Venice, about 1450 A. D., which were famous for their great torchlight processions, mark the culmination of this period of sense craving.

But other changes in the national consciousness accompanied this craving for new and strong sensations. Burckhardt ( $\left.{ }^{3 \tau}\right)$ says,

"In the Middle Ages man was conscious of himself only as a member of a race, people, party, or corporation, but now the subjective side asserted itself and man became a spiritual individual and felt himself as such."

Adams ( ${ }^{38}$ ) says in substance that the Renaissance was more than a revival of learning. It was a revival of emotions also, an awakening of man to a new consciousness of himself and 
the world. The work of the Renaissance was to awaken in man a consciousness of his powers and to give him a confidence in himself. It was a craving for freedom more than anything else which characterised the times. There was a: change from outer to inner control, and the) result was that there was a time in which there was no control at all. Hence the great vices of the period.

Burckhardt $\left({ }^{39}\right)$ sums up the character of this age by saying, "The fundamental vice of this character was at the same time a condition of its greatness, namely, an excessive individualism. This immorality was a historical necessity; with it has grown up a modern standard of good and evil." Symonds $\left({ }^{40}\right)$ also takes this ground in explaining the illicit loves of this time, saying that they were not merely sensual, but were due in great measure to the demand for imaginative excitement in all matters of the senses.

Intemperance and strong cravings for excitement and intoxication are not only found at crises in development but are characteristic of strong and dominant races. Our warlike ancestors of the Saxon races and their descendants through all historic periods have shown a great love of intoxicants. Great warlike exploits were always associated with great feasting and deep drinking. It was a part of the man's 


\section{PSYCHOLOGY OF INTEMPERANCE}

equipment to be able to take his place in the feast as well as in the fight, and the former sometimes required no less hardihood of body and mind than the latter. This spirit was part and parcel of the rough virtue and courage and force, which have made the Saxon race dominant. Crude virtues can be transformed and polished, and even vices may be utilised and may furnish the basis and need of control and law; but where there is no force there can be no growth, and no culture. Everywhere the, warlike and creative spirit and intemperance . go together.

It is evident that as society becomes complex, we can no longer speak of the intoxication impulse as a single, uncomplicated motive. The ( use of intoxicants is founded upon complex passions and many interests and motives enter. At different times in the process of development and decay of nations, different impulses are dominant. The effects of intoxicants differ, and the effects of the same intoxicant vary much according to the purpose and manner of its use. The same drug may both arouse and depress feeling. The same drug may be used, in the one instance to excite more pleasure and to create more abundance of life; and again to decrease pain and relieve from effort and to alter in other ways the states of consciousness. Thus far we have dealt mainly with the in- 


\section{CIVILISED NATIONS' DRINKING 51}

toxication motive that accompanies, and is a part of, the impulse to seek the larger life, and

- that expresses a craving for more pleasure and more activity. But as we approach the later stages of civilisation, other motives begin to appear and sometimes to take the lead. One at least, the narcotic motive, plays a great part in history. This needs more precise attention than has hitherto been given it.

The narcotic impulse is essentially, it seems, a, desire to revert to more primitive states of consciousness, accompanying a condition of high pressure. In its temporary and mild forms it is the expression of the desire for rest. It is associated with relaxation, recreation, dreamery, and with all that relieves from toil and trouble. In its more abnormal aspects it is the impulse to escape from the struggle of life-to produce an artificial satisfaction of the will, to soothe, and sometimes to arouse jaded forces, and to create artificial pleasures. This tendency of tired man has often expressed itself in dreams of a golden age in the past. It has created mythic accounts of Fountains of Youth, of Paradises in remote lands, of Utopias, and Nirvanas. All these are expressions of fatigue, of a longing away from a too tonic environment. This spirit is also the keynote of mysticism, the constant theme of which is Rest, to be relieved from pain and weariness. The cry of Back to 


\section{PSYCHOLOGY OF INTEMPERANCE}

Nature! which is raised whenever the accumulated weight of culture, conventionality and duty becomes burdensome, is in some of its aspects but another expression of the same motive. Nietzsche sees the true nature of the motive, hence his contempt for pity. "What we need," he says, "is pain, more pain." Again he speaks of the two great European narcotics,

$\downarrow$ Christianity and alcohol. These he places together doubtless because he recognises in both the effort to seek artificial means of escaping pain, in both a means of compensating or palliating the sternness of reality. "Pain spurs the nervous system on," says Mosso. It normally creates states of second breath, and arouses the higher enthusiasms. The seeking of artificial means of alleviating it, whether it be by narcotics, or by socialistic schemes and Utopian dreams is an expression of the longing backward, away from the influence of natural selection and the struggle for existence; it is failure of the will to live, while the intoxication motive is optimistic, representing the will to live, and the desire for more life. , The sthenic intoxication motive thrives in an atmosphere of belief in a future. Excitement of any sort seems to quicken belief. Stimulants arouse it, for such belief is the expression of an instinctive craving for life. Narcosis, on the other hand, is centred in itself and in the past. It is 


\section{CIVILISED NATIONS' DRINKING 53}

not the attitude of outlook or growth. It is this motive which a nation must keep from spreading in its life; for like the hardened artery of senescence it indicates the end of growth and the beginning of decay. It shows that society no longer meets pain and need with effort, and so overcomes it, but succumbs to environment, and seeks ease and rest and surcease from toil, or the delusion of a dream world.

Not only are whole stages of the history of nations affected by the narcotic and other related motives, but within the general movement of social development, periods may be detected in which various classes of society show, independently of the rest, the degenerative forms of intemperance which accompany decay of civilisation. Whenever nervous exhaustion becomes extreme, or there is a time of national distress or reverse, the intoxication motives are likely to express themselves in low forms. Then the sensuality of decadence ensues which is found in the degenerate days of all nations. There may be also temporary periods of stagnation or retroversion or aberration, in which the same phenomenon is seen; for example in France, in the time following the Napoleonic wars, when overstrain and fatigue had brought on an extraordinary craving for excitement and new sensations. This impulse then found expression in many ways; especially the litera- 


\section{PSYCHOLOGY OF INTEMPERANCE}

ture of the period reflects it-and it is seen most characteristically in the work of Huysmans, $\left({ }^{41}\right)$ the novelist, and also in all that school of decadents that made a fetich of sensation.

The intoxication motives, as expressed in our own national life, present peculiarly difficult and complex problems. We find here a very intricate society: classes intermingling and influencing one another; immigrants with Old World ideals and habits side by side with native stocks, and amalgamating with them; we see rapid growth in some parts, comparative stagnation in others; we observe stress, fatigue, abnormality, possibly degeneration of some of the elements already setting in-all making an intricate and bewildering web through whose strands and fibres all the intoxication motives are at work at once.

We have passed a first period of rapid growth and simple pioneer life, when the spirit resembled in some respects that of the early Renaissance, when our ideals were not those of culture and temperance, but of force, progress, and conquest of nature and life. This pioneer spirit has pushed further and further west, and has been followed by an ideal of higher culture, and more controlled and definitely purposeful activity. As a part of this practical ideal of efficiency and ethical ideal of 
culture and self-control, there has grown up the ideal of the temperate life, which tends to spread throughout society to check the intoxi-) cation motives.

But mingled with this note of progress and control is the narcotic motive, an expression, perhaps in the main, of normal fatigue and desire for relaxation from a strenuous life; but in part a sign of cessation of growth, of exhaustion and abnormality-in individuals and also in classes. Some classes seem permanently arrested in development; and here there is social life on a low plane, with the excessive development of the saloon. Alcohol takes the place of the higher enthusiasms, and there is no initiative from within, nor strong enough force from without, to change the currents of desire upward. Here too there is abnormality, fatigue, and degeneration yielding to narcotic habits to relieve pain. In the higher classes, indifference to progress on the one hand, and over-culture and nervous degeneration on the other, are sufficiently prevalent to threaten defeat of some of our ideals. There is in our midst a widespread influence of narcotic motives, seeking to cope with weariness and pain in ways that are fatal to progress. It is this spirit which most of all must be combated and delayed in a nation; a spirit, which, when it ceases to be individual and sporadic, and be- 
comes the dominant mood of classes or of a nation as a whole, marks the beginning of decline.*

Without attempting to carry out in detail the parallelism between the individual and the race, we must refer once more to the similarity between phenomena of growth in the two aspects of development. The period of accelerated growth such as the early culture periods of Greece, the Renaissance, and our own first century of history are repeated in the stages of development of the individual, when he passes. from childhood to adult life. In the individual the change is precisely that described by Adams as the course of progress in the early decades of the Renaissance, when there was a change from outer to inner control, in morals, religion, and in all other departments of life-and, for a time, no control at all. At adolescence, the human being becomes a complete individual. New forces arise in him, taking origin in the

* How intricately the intoxication motives are bound up with every phase of our life can be seen from such statistics as those gathered for the Committee of Fifty and published in Economic Problems of Intemperance and the Liquor Industry. It is estimated that the liquor industries support 1,800,000 people in the United States, and that about 80 per cent. of adult males use intoxicants to some extent. The average consumption is 1.46 gallons of distilled liquors and 18.04 gallons of malt liquors (1903). The effects of alcohol upon many trades, upon crime, politics, pauperism, disease, is very great. 


\section{CIVILISED NATIONS' DRINKING 57}

instinctive life, at first confused and unco-ordinated, but providing the raw materials of all the enthusiasm and controlled powers of adult life. Now the whole attitude of mind may be described as dominated by the intoxication impulse. Vice and ideality are not clearly separated from each other; the individual is reaching out for new meanings of life, for a life more abundant. Impulse is stronger than the powers of control, and the temperament is all positive-looking forward to life with intense feeling and desire for action. As we shall see later it is at this age that the intoxication habits become fixed in the great majority who acquire them. The individual is undergoing a transformation of his interests from lower to higher forms, and if this process does not proceed freely under favorable conditions of environment the lower enthusiasms and intoxications become fixed for life, and are not transcended, or transformed in the higher. At this point several of the lower motives of intoxication impulses are likely to creep in. Habit may develop on the basis of bad nervous organisation. Excessive craving for sensation may dominate consciousness, or the social life may become fixed upon a low plane. The emotional life may turn toward depression, and prematurely the motives of pain and narcosis appear, indicating the end of growth before it has really 
begun. When, in the individual, intemperance and drug habits appear after the first period of adolescence, they are far more likely to be caused by pain and the narcotic motive, thus resembling the phenomena we find in the life of nations.

These views give us a clue to the psychology of the sex differences in intoxication habits. Everywhere there is more drinking among males. In many places laws have prohibited the use of intoxicants to women, and in others public sentiment and custom forbid. But we must look deeper than law and custom for an explanation. The erethic and orgastic psychoses belong especially to the male temperament. $\left({ }^{42}\right)$ This can be seen among animals as well as in the human species. The love dances among animals are practised by the males. Physiologically, the habit of the male is described as erethic or katabolic, that of the female as anabolic. Those states in which energy is raised to a high tension to be forcibly expended are masculine, and we must suppose the difference is rooted in the difference of the physiological mechanisms of the sexual life. These differences appear throughout the whole history of the race. Ellis $\left({ }^{43}\right)$ says, for example, that among primitive peoples, occupations which require intense activity alternating with long periods of inactivity are always 
chosen by the male, while occupations that involve monotony and repetition fall to the lot of the female. As civilisation has advanced there has been a tendency for these rhythms to be obscured, and in many respects the male and the female habit have become more alike. Practical considerations now require that man's activities be to a certain extent routine and monotonous, but the old habit remains latent. At adolescence it prevails in the life of every normal individual, and throughout life it persists, determining no doubt our seasonal cravings, our vacations, and it is quite likely the basis of the periodical drinking of the abnormal type. Work normally takes up in part the capacities and cravings for erethic and excited states and directs energy in a more even flow, but when control is relaxed or the organism and its activities are imperfectly integrated and ill adapted to life, the old erethic rhythms may prevail. Woman has far less of this habit, therefore she is less prone to intoxication motives. Her body is more likely to suffer injury and her functions to be disturbed by erethic activities. Hence we find that the motive which in women leads to drinking is likely to be pain; that her use of intoxicants is more likely to be solitary; that the narcotic effects of drugs are more pronounced in her, and. are more often sought. 
This review of the facts about intoxication in animals, in primitive and civilised peoples, and in the individual, incomplete as it is, has already suggested many points of view and some conclusions, which we must later consider in the practical study of intemperance. If precise and certain conclusions can seldom be reached, the depth of the psychological motives which enter into the drinking habits of civilised man: the heredity, so to speak, that lies behind them, seems at least to be apparent.

A few words of summary will serve to bring the facts to sharper focus. The use of intoxicants has been shown to be almost, though seemingly not quite, universal; so nearly, however, that exceptions are quite noteworthy and have attracted the attention of observers. Intoxication appears to have originated in the social life, and there is much to convince us, in the religious ceremonial. It is highly probable that the use of fermented drinks began in producing intoxication, rather than in the moderate drinking of them as beverages, which seems to be a degenerate form of their use, and to have come late. A careful examination of the ethnological literature fails to disclose the fact that taste was much concerned in the use of intoxicants, or had much to do with the discovery of them. Uncivilised man in his natural state is not a steady and habitual drinker. 
Drinking, for him, is not mere drinking. He drinks alcohol occasionally to secure some degree of intoxication, and usually for a purpose. His drinking is likely to be periodic, and in general it is characterised by great excess and uncontrolled excitement.

In view of these facts it is unscientific, at least, to regard the drinking of alcohol as merely a sin: something that man has acquired as the result of a fall from a primitive state of virtue, as the crude ante-Darwinian theology declares. The fact that almost every primitive and savage people has succeeded in discovering an intoxicating drink must be taken into account; that among these peoples drinking to intoxication, instead of being regarded as a sin, was approved by custom and conscience. They drank in their sacred rites, and the widespread prevalence of intoxication cults leaves no doubt that the state was naturally and habitually thought an inspired condition, in the closest relation to the part of life thought to be most significant and profound. The savage, strange as it may seem to us, drank and prayed in the same act. The fact that intoxicants were used publicly shows that their use was far removed from those acts that are covered with shame. These arguments do not lead in the least to the view that intoxication at the present time is normal or right; but they do show 
that, to the extent the whole manner of life of the savage is natural, sane, and good, the intoxication cult partakes of the same qualities. To the savage's mind drinking is not immoral; indeed, according to his belief, there was no function of life too solemn or too sacred to be accompanied by intoxication, or at least by the use of intoxicating drinks.

When whole races of people, widely scattered over the earth, are found to indulge in a practice, when these practices are found to have the most intimate connection with the social and religious life, and are not the result of fad or fashion but grow out of deep beliefs, we must be cautious, we insist, about naming these practices either abnormal or immoral. For it is likely that the words may have no significance. If we can find no morality nor sanity in the most forceful and productive impulses of human nature, we may become suspicious of our moral judgments themselves, which are grounded upon quite similar roots of the emotional and instinctive life. If, on the other hand, we can explain and justify nature, and discover value and progress in the means nature has taken in producing civilised man, we shall find ourselves with a far better command of scientific principles and practical formulas, than if we merely pronounce abnormal that which we do not see to be in accordance with 
our present ideals. It is very important to discover precisely the significance of intoxication in nature's scheme of development of man, to understand what its use may have been in the early stages and in laying foundations for later growth. What would civilised life now lack if alcohol had never been discovered, and intoxication rites had never been practised? Already we have answered these questions in part by asserting some very general principles; but we may go still further and see in detail other ways in which alcohol has been the servant of man.

Alcohol and its kindred have been of great importance in fostering those social characters upon which our present civilisation rests. It is difficult to conceive, in fact, what the social life of uncivilised man might have been without the use of alcoholic drinks. The greatest of obstacles to social amalgamation, to treaties, to intercourse among tribes were overcome by the intoxication festivals and the drink customs. Alcohol removed, temporarily, the natural suspiciousness of the mind, favoured common meeting grounds of thought and feeling, and broadened the whole social horizon. It is possible, indeed, that alcohol may have been the deciding factor at a certain stage of civilisation, when man's future as a social being hung in the balance; when, whether he should remain in a narrow tribal stage, or form wider social groups 


\section{PSYCHOLOGY OF INTEMPERANCE}

depended upon his social impulse. This must have depended greatly upon the quality of his social feeling, and we have had abundant evidence that this was profoundly influenced by alcohol. By the influence of intoxicants a wider area of common ground upon which tribes differentiated by environment could meet and co-operate, was produced.

Within the tribal group, too, the influence of

$\int$ alcohol must have been in the direction of more complete socialising. It broadened the range of social feelings and let down barriers of reserve and suspicion. Ability to segregate and unite mentally in common social and religious functions, has been one of the most potent factors in civilising peoples. Alcobol, we may say, has helped to carry social feeling beyond the range of the home life, and thus has assisted in developing the internal structure of the social groups no less than the amalgamating of tribes.

Law, custom and control, both individual and social, were also fostered by intoxication cults and practices. Drinking, with its dangers of excess and violence, its excitement and abandon, must have been a powerful stimulus to the growth of law and custom. In the intoxicated state the emotional power and danger of the human individual is shown, and the need of regulating his activities by law forces itself upon the attention. Hence the very rich and 
varied ritual and custom which cluster about the use of stimulants, curious remnants of which we still have, in the drinking codes among students and military groups. Much of the early stimulus to the formation of codes of public behaviour, the regulating of actions between man and man, much of etiquette in general has undoubtedly had its origin in the use of intoxicants.

Turning to the more individual effects of alcohol, still other relations of intoxication to mental development will be found. In the state of intoxication the individual not only comes into closer touch with his associates, but he becomes more open to belief in the supernatural. How great the influence of alcohol may have been in establishing religious beliefs no one can now fully demonstrate, but in primitive minds, having a high degree of suggestibility, and a narrow range of experience, its influence must have been great-as important, it is likely, in the religious life as in the social life.

In still other ways the effect of intoxication upon the individual can be detected. States of high excitement and intoxication, however produced, and whatever their effect upon the organism may be, serve the purpose of broadening the emotional life, give the individual a broader experience of both pleasure and pain, show the possibilities of the imagination, set ideals of in- 
dividual effort and success, and give new conceptions of both mental and physical energy. There can be little doubt that the conception of the strength of body and mind attained in the states of intoxication has been an important factor in creating confidence in the power of the human individual to control the forces, natural and supernatural, that surround him. When we come to examine the intoxication motive as it appears in present society, both in normal and in abnormal individuals, we shall see that the same attitudes still produce the same results; that by his states of excitement, which are often kinetic equivalents of drug intoxication, the individual gains his conception of his powers, and in them ideals are set which control all his future development and conduct.

Considered in its most general form, the intoxication motive must be regarded as a native or instinctive quality of every growing individual. The craving for, and the impulse to seek, states of high intensity are so characteristic of childhood and youth that they must be regarded as an aspect of normal growth; and we must suppose that both the capacity to endure such states and the effort to secure them have been the objects of natural selection. Those organisms which can produce the highest degree of power or feeling without injury to the tissues are likely to survive, because they. 
possess qualities which favour not only continued growth, but make for effective adjustment, and vigorous attack upon practical problems. We must suppose that both the capacity to endure excitement and the tendency to seek it have increased. By these states the powers of the individual have been extended and the organism has been kept plastic.

Precisely what the physiological mechanism of these states and the impulse to seek them is, can for the most part but be conjectured in our present knowledge of physiology. We may suppose, however, that they make use of, or are produced on the basis of, mechanisms that have been established for practical use. The relation of the intoxications to the sex erethisms has been suggested. This is made still more probable by the history of the intoxication impulses in the life of the individual. They serve the purpose, on the mental side, of directing the energies away from the central instinct of sex. They provide exercise, we may think, for vast forces in the organism, which are always in danger of diversion and establishment on low planes, yet which must be made active if the higher enthusiasms and interests are to be aroused. All these impulses to seek excitement, all the phenomena of second breath, ecstasy, religious excitement, have their place in the life of the individual as the raw materials of en- 


\section{PSYCHOLOGY OF INTEMPERANCE}

thusiasm; they exercise the powers of the body and mind, and are the parents of that controlled mental action which later appears as the longsustained attention and enthusiasm and endurance of work. The intoxication motive that leads to the use of alcoholic and other intoxicants is best interpreted as one expression of a more general impulse which is deep-seated in the race, and is indeed fundamental to development, very far-reaching in its effects, and multiform in its expression.

The purely physiological point of view that is often taken in estimating the place, in the economy of life, not only of intoxicants, but of many habits and functions, is but partial. Demonstration that alcohol is physically harm-

ful does not determine its place in man's evolution. Much that is in itself harmful or unhygienic has been utilised and turned to advantage, even made physically hygienic on broader grounds than its immediate effect.* The lesser evil is often employed by nature to lead to the larger good. The fatigue products of the body are to a high degree poisonous to tissues, yet their presence seems necessary for the full development of the powers

* The appetite for some poisons, Sir James Paget claims, has already been justified by science; and the use of alcohol, which is the most widespread and persistent of all, will also, he thinks, one day be fully explained and justified. 
of the organism. Even when they are produced in excess they may become the means of extending the capacities of the body; and the harm they have caused may be more than compensated by increased activities of important functions. The body seems sometimes to thrive and increase in power under conditions that produce an abnormal degree of exhaustion or poisoning. New powers are brought into action in such states, and resources of the organism are marshalled and organised in a way that is never accomplished by moderation. It is quite possible that at certain stages of development practices that may leave permanent deleterious effects upon the organs of the body, and may even cause lesions, have been more than compensated by greater power of function; and that our bodies have been produced by such a compromise. Parts have become less perfect that the whole may be more perfect. We may well have sacrificed as a race many a possibility of physical perfection, and have suffered many injuries, in order to acquire some practical function. By means of the capacity thus gained, we may later have created the cure for the evil from which we have suffered, or may have overcome its effects in other ways. Individuals, like races, suffer harmful effects for the sake of greater efficiency. 


\section{PSYCHOLOGY OF INTEMPERANCE}

Such a view as this, which is borne out by much evidence, has a far-reaching application to the problems of both the individual and the race, in both their theoretical and their practical aspects. If it is not sound it is difficult to understand fully the logic by which nature has introduced apparent evils at so many points of development, and has allowed such wasteful forms of activity. 'All such conclusions, we must emphatically assert, may be formed without in the least committing one to the view that any form of intemperance, or any use of alcohol or of any other intoxicant is at the present time justified. 


\section{CHAPTER V}

THE INTOXICATION MOTIVES IN LITERATURE, LANGUAGE, FOLK-THOUGHT AND MEDICINE

Intoxication, which has been so intimately connected with the development of the social, the religious, and the practical life, has left an impress upon language and literature at every step, and has been no little influence in shaping religious and philosophic thought. We have already learned of the close connection between intoxication and religious feeling, and how intoxication has inspired ideals of a future life, confirmed belief in it, suggested attributes of the Divinity, and has actually created gods. Of the many deities of drink two, Dionysus of the Greeks and Indra of the Hindus, are universally known; but there are many others, similar in their nature to these, and undoubtedly created in the minds of men from similar motives-to explain the state of intoxication, and express the mystery and feelin $\Omega$ realised in it. Among lower races, for example the ancient Mexicans, drunkenness has its special deity. The Nirvana and other philosophic heavens of eastern peoples, we may suppose, have been sug- 


\section{PSYCHOLOGY OF INTEMPERANCE}

gested by the use of narcotics, such as opium; at least it is safe to assert that the narcotic dream of bliss has been one factor in creating them.

The origin of wine has been an insistent theme in primitive thought, has roused varied speculation, and has been woven into many myths. Among all these myths of wine in primitive literatures, the common element is the belief in its divine origin. There are many stories of the use of wine by the gods; its virtues are extolled as divine; and the use of intoxicants is often included among the pleasures of the next world. In the lower strata of literature, in fairy-story, folk-lore and legend, the intoxicating liquor often becomes the love potion or philter; elixirs and waters of life, which are usually stimulants and narcotics, appear in an endless variety.

The remarkable influence intoxication has exerted upon popular thought is shown by the great number of terms for the state of intoxication which have been in common use. Ribot $\left({ }^{44}\right)$, quoting from Renan, remarks that a people usually have many words for that which interests them most. If this be a true test of interest, intoxication has had a strong hold upon man; for certainly nothing except the sexual relationship has made a deeper impression upon popular language. Slang, especially, expresses 
undercurrents of thought and feeling, and brings to the surface that which is suppressed, forbidden, or aborted in daily life. That such a variety of unwritten terms has survived and spread shows how forceful and persistent are the undereurrents in which the intoxication motives move-and how great a power of interest has run to waste in our higher stages of civilisation.

Below is printed a list of terms used in English to describe the state of intoxication. The list was collected from the literature of slang and from other sources. No attempt was made to make it even approximately complete, for the purpose was rather to indicate the range of fertility of the language when inspired by intoxication motives, than to contribute an exact study of language itself. The derivation and significance of some of the terms are apparent; in other cases the meaning is obscure. Some of the terms are obsolete, and are to be found in old English writings. Some local terms are included. Some are in wide use. Translations from German and French have been omitted. It is likely that in other languages there is quite as rich a vocabulary of intoxication as in English. A list of more than six hundred words in German has been collected. It is interesting to notice the aspects of intoxication that have been most singled out for characterisation. 


\section{PSYCHOLOGY OF INTEMPERANCE}

Many of the terms are words for contempt, having reference to the extreme state or last stage of intoxication, and were inspired by a sense of humour.

\section{SYNONYMS FOR INTOXICATION}

A bit on, addled, all key-holes, all mops and brooms, all sails set, a passenger in the Cape Ann stage, artificial, at rest.

Bacchi phenus, back teeth afloat, bamboozled, banged up to the eyes, battered, beastly, been among the Philistines, been at a ploughing match, been flying high, been hit by a barn mouse, been lapping the gutter, been in the sun, been rushing the growler, been sucking the can, been taking bitters, been taking tea, beery, bended, blowed, blind drunk, blowing, blued, blue-eyed, boiling drunk, borey-eyed, boosey, breesy, brick in the hat, bright in the eye, bruised, budgy, buffy, bummy.

Canonized, can't say "National, Intelligence," can't see a hole in a ladder, caught a fox, caught favour, channels under, chirping merry, chuck full, elear, clinched, cocked, come from Liquor Pond Street, comfortable, concerned, corned, cosey, eoxy-loxy, croaked, cronk, crooked, erook-in-the-elbow, crying drunk, cup-shot, eut.

Damaged, dazed, dead drunk, dipped deep, discouraged, disguised, done over, doped, down in the mouth, down with the barrel fever, drowning the shamrock, drunk, drunk and disorderly, drunk and dressed up, drunk as an ass, drunk as a boiled owl, drunk as a brewer's horse, drunk as a drum, drunk as a fiddler, drunk as a fish, drunk as a fly, drunk as a Glassport fiddler, drunk as a lord, drunk as a mouse, drunk as an owl, drunk as a piper, drunk as a tapster, drunk as a rat, drunk as a sow, drunk as a wheelbarrow, drunk as Bacchus, drunk as can hold together, dry, dull in the eye.

Edge on, electrified, elevated, exalted, exhilarated.

Faint, far gone, feeler on, feels good, feels his oats, feels right royal, feverish, filled to the brim, flag of defiance out, ftatch-kennured, flawed, fluffy, flummoxed, flush, flustered, 


\section{THE IN OXICATION MOTIVES}

flustieated, fly blown, flying high, fogged, fogmatic, forward, fou', four sheets in the wind, fow, foxed, fresh, fuddled, full, full cocked, full of ballast, full of pots, full of rum, full to the brim, full to the bung, fuzed, fuzzy.

Gilded, gilded o'er, gilt edge on, glorified, glorious, goggle eyed, got a big head, got a bundle, got a drop in the eye, got a smile on, got the gravel rash, greetin' fou, groatable, groggy, gutter legged, guzzled.

Had an eye opener, half and half, half cut, half on, halfshot, happy, hard up, hasn't got his sea legs, hazy, headed for port, head light on, head on, heady, hearty, helpless, high, high lonesome, hilarious, holds up the lamp post, hoodman, het, how came ye so, how fare ye.

In a difficulty, in a very good humour, in his altitudes, in good fettle, in good spirits, in his cups, in liquor, inspired, in the blues, in the gutter, in the wind, intoxicated, irrigated, iskimmish.

Jagged, jagged up, jag on, jammed, jib well bowsed, jimjams (has the), jolly, jovial, jug-steamed.

Kisky.

Laid away, leery, legs broke, limber, loaded, loaded for bears, loaded to the gunwales, load on, looking lively, loose, lumpy, lushed, lushy.

Main brace well spliced, making m's and w's, martin drunk, mawled, medza-beargeared, mellow, miraculous, moony, nıoppy, mortal, muddled, muggy.

Nazie, night eap on, not in a fit state for discussion.

Obfusticated, off his nut, on a blow out, on a bust, on a hurrah, on a skate, on a spree, on a tear, on a triumphant, on his fourth, on the batter, on the beam end, on the beer, on the fuddle, on the gay galoot, on the lee lurch, on the loose, on the muddle, on the nipple, on the rampage, on the ran-tan, on the re-raw, on the slyte, on the stuff, on the tiles, one sheet in the wind, ossified, out of funds, overcome, overstocked, over the bay.

Paralyzed, peckish, petrified, pickled, pificated, piper-fou', ploughed, podgy, pretty well entered, primed, pruned, pushed.

Queered, quaffed the bowl, 
Raddled, rather touched, razzle-dazzle, reeling, right, romeo, roaring, roaring drunk, roaring fou', rococo, rotten drunk.

Salted down, salubrious, sawed, scammered, screwed, sees two moons, set up, sewed up, shaking a cloth in the wind, shaky, shaved, shocked, shot, shot in the neck, skaty, skate on, sleepy, slewed, smashed, smeekit, smelling of the cork, smoled, snakes in his boots, snubbed, snuffy, soaked, society slant on, soft, soused, spiff, spiffed, spoon drunk, spoony drunk, spreeish, sprung, squiffed, staggering full, starchy, stewed, stimulated, striped, stropolus, stuffed, sun in the eyes, swiped, swipey.

Taking it easy, tangle legged, tanked up, tavered, thirsty, three sheets in the wind, tight, tight as a brick, tipsy, tired, tired feeling (has), titley, too much fire water (had), took a snort, top heavy, touched, transmogrified, turkey on his back, twisted, two sheets in the wind.

Unco', under the weather, under the influence, unsteady, up a tree.

Walks on a bias, water logged, waving a flag of defiance, weak-jointed, weary, well under way, wet, whipped, whittled, wincy, wobbly.

Yappy, yaupish.

The intoxication motives, as they appear both in poetry and prose, furnish another field for psychological study. There are two great themes clearly expressed in this way. One is the glorification of pleasure and abandon, and praise of the abundant life; the other portrays the desire to escape from pain, to drown sorrow, and to rest. The best example of the first motive is found in the Greek dithyrambic poetry, which has already been mentioned in another connection. The same spirit of abandon, love of exaggeration and excess appear everywhere 
in the literature of drink. Such verses as the following show this mood, which is quite characteristic of the drinking song and verse:

\section{"When I am dead with wine my body lave, For obit chant a bacchanalian stave."}

Omar Khayyám.

"The dry and dusty earth drinks, The trees too drink her moisture; The sea doth drink the rivers, The sun doth drink the sea waves. The moon doth drink the sunbeams, Why cavil then at me, friend, That I am fond of drinking?"

Anacreon.

In the college song books drinking is the most common theme, excepting love. Here the spirit is for the most part, like that of the Greek dithyramb, one of jovial excitement and love of abandon; but there is also a thread of shallow pessimism, of young life precociously wise in experience. The praise of drink as a cure $\int$ for care and trouble is frequently sung, but often in a way that indicates that the experience from which the pessimistic note comes is ideal rather than actual. But this tone of pessimism mingled with the joyousness and freedom of youth is prophetic of the more serious pessimism which riper age sings. The poetry of Omar Khayyám expresses the narcotic motive more fully than any other, and must serve as our one illustration of the theme which appears 


\section{PSYCHOLOGY OF INTEMPERANCE}

in so many forms in the literature of drink. Some interpret the quatrains of Khayyám as symbolic-as clothing the Deity in the form of wine, as did Hafiz and other Sufi poets. If this is true it is another proof of the religious significance of intoxication. But Fitzgerald ( ${ }^{45}$ ) rejects this view, saying that Khayyám is just what he appears to be-a material epicurean. Through all this poetry runs the narcotic theme. He frequently refers to the wheel of heaven and the world's injustice. He hates the hypocrisy of the pious, and bitterly charges the sins of man to the account of the Creator. For him wine was a means of relief from care, fatigue, and trouble. He says:

"Endure this world without my wine, I cannot;

Drag on life's load without my cup, I cannot."

And again,

"Life is a poison rank, and antidote save

Grape juice there is none."

And he sings what many drunkards say when they declare that drink dims all other pleasures of life, for he cries:

"They preach how sweet these Houri brides will be, But I say wine is sweeter, taste and see."

Much more might of course be added to this account of the effect upon literature of the in$\checkmark$ toxication motives, and the manner in which 


\section{THE INTOXICATION MOTIVES}

these themes have been expressed in verse and song. Interesting as it might prove to follow out this topic, its value would perhaps be greater for the psychology of literature and language than for the psychology of intoxication, for the motives which we are studying are expressed in other ways more accessible to interpretation. But we may emphasise the profound effect these motives have had upon the imagination, one evidence of which is to be found in the study of literature.

The direct effect of the state of intoxication and stimulation by narcotics and intoxicants upon the production of the literature is another theme full of interest and psychological suggestiveness. Many examples are known of writers who, whether intentionally or not, have found inspiration in excitement caused by $\checkmark$ alcohol and other drugs. One may mention Burns, Byron, Coleridge, De Quincey, Poe, as examples among moderns of many who have been similarly influenced in their work by artificial stimulation. The effect upon the spoken word has also been great. Alcohol has played a part, not only in making men impressionable and receptive to the influence of the eloquent word, but has roused and stimulated the language sense, and the feeling upon which it is based. There are many stories of great speeches inspired by intoxicants, but it is likely 


\section{PSYCHOLOGY OF INTEMPERANCE}

that for genius that has thus been excited or expressed the world has paid a good price in other work ruined or confused.

Another historical aspect of intoxication demands brief mention in this connection, for it shows how intoxication motives have influenced another great field of thought. That is, the theory of stimulus in medicine $\left({ }^{46}\right)$. It would be difficult to prove definitely the connection between modern medicine, and the ancient practices of the shamans, but it would be strange if beliefs and rites which played so great a part in primitive medicine, as did intoxication and its cults, had not been re-echoed in a later day.

The doctrine of stimulus has had a long and interesting history in medicine. The dualistic theories of Aristotle and Plato, which placed the soul and life in contradistinction to body and matter, were absorbed into the theory of medicine at an early date. Life came to be regarded as an entity or principle which opposed or controlled the body. In order to cure disease this vital principle must be spurred on to increased effort. Hence the disproportionate use in medicine, even down to our own day, of drugs that affect the mind, and the slow adoption of remedies which act upon organs whose functions are not directly reported to consciousness. Many celebrated early physicians, in- 


\section{THE INTOXICATION MOTIVES ' 81 .}

cluding Galen, Paracelsus, van Helmont, and Hoffman, assumed a life principle which must be assisted by stimulation when it strives with disease.

In our own day, although the theory of a life principle presiding over the body has been abandoned, and the seat of life has been transferred to the tissues themselves, the old doctrine of stimulus still remains. Stimulants and narcotics still play a disproportionate part in medicine, and it is significant, as has recently been shown, that the success of the patent medicine industry has depended upon the fact that alcohol is the active principle almost universally used, and the effect of most medicines of this class is a mild intoxication. These medicines, appealing as they do to the uneducated, perpetuate beliefs and practices that are in essentials like those of primitive man. No doubt the medical scientists, the charlatans, and the shamans have all had a profound truth on their side in inducing intoxication to cure disease, though they have but half understood the power of the aroused consciousness to cope with the physical disorders of the body. This is a power whose usefulness has not come to an end with the abandonment of the crude theories of stimulus-but is one which we are just beginning to understand, and to control by our more refined methods of psychotherapy. 


\section{CHAPTER VI}

MENTAL AND PHYSICAL EFFECTS OF INTOXICANTS AND NARCOTICS

WE have now traced, in its main outlines, the genesis of the intoxication impulses. This genetic study involved an investigation of the intoxication motives, as they have developed in the race, from animal life, through the stages of primitive and savage culture, and on to stages of growth and decay of civilised nations. By comparing this movement with the development of an individual, and considering the intoxication motives in society in their relations to other impulses, we have seen that they have been connected at every period with the growth forces and impulses of individual and society. How these impulses become transformed and radiate out into many departments of life, as life becomes complex, has also been explained, as well as the manner in which degeneration sets in, when growth forces fail to carry the organism, whether of individual or society, to higher stages; and how the narcotic impulse arises as a result of pain, fatigue, and \rfloor old age. 


\section{MENTAL AND PHYSICAL EFFECTS 83}

Such a view as that to which we have been led by the genetic study of intoxication will serve as a foundation upon which further study may be made. It must be taken into account by any theory of intoxication, or any theory of control of the present evils of intemperance. Yet no such result can be regarded as conclusive nor complete; the problem must be attacked from other quarters, by other methods.

One such method seems to lie ready at hand. It may be called the analytic method. It can be applied to two problems. First, the state of intoxication itself may be studied in many ways, in order to discover what, precisely, intoxication is. We need to know about both mental and physical effects of alcohol and other stimulants and narcotics, both in small doses and in large doses. Such problems are open to experimental methods. Stimulants may be administered under controlled conditions, and the mental and physical effects of them can be measured by instruments of precision.

Another promising method is the study in detail of the intoxication impulse as it is felt by individuals possessing it, especially those who have it in a pronounced or abnormal degree. The abnormal case is nature's experiment; and by an analysis of this the normal case may better be understood. The study of the genesis of these abnormal or extreme cases will be likely. 


\section{PSYCHOLOGY OF INTEMPERANCE}

to throw further light upon the nature of the impulse.

The drugs which are commonly used for purposes of intoxication and narcosis, though differing greatly in chemical composition, may be grouped under a single class, considered with reference to their physiological effects. According to Anstie, ( ${ }^{47}$ ) they are all stimulantnarcotics; that is to say, when taken in small doses, or as an initial effect of large doses, they stimulate the nerve cells; and in large doses they invariably produce narcosis. It is true of most, if not all of these drugs, that whether applied to a single nerve fiber, or to the nervous system as a whole by way of the circulation, they produce first a stage of in- 1 creased excitement, followed by a stage of lessened excitement. Mentally, effects are analogous-a stage of exhilaration is followed by a stage of depression. Stimulation, according to Anstie, is an increase in the normal functions of the nerve cells, while narcosis is a paralysis of these functions. Most of the phenomena that occur in intoxication, he says, are due to narcosis, and not to stimulation. At the present time many writers would deny that alcohol is ever a true stimulant, and say that the initial excitation is rather a protective irritation, or a paralysis of inhibitory mechanisms, 
than a true stimulation. Schmiederberg, Bunge, Lauder-Brunton, Kräpelin, and others hold to the view that all the stimulating effect of alcohol is abnormal in character, while Bing and his pupils maintain that alcohol is a true stimulant. Microscopical studies of the effect of alcohol have shown that under its influence the chromophile bodies, which represent the potential energies of the nerve cells, become either more rapidly exhausted or less rapidly deposited, leading to a depletion of nerve cells, but whether this process begins with the first effects is not certain.

In general, whatever the character of the excitement may be, it can be said that the first effect of alcohol (though there may be exceptions) is to excite tissues. A still wider generalisation may be made. All poisonous substances that finally destroy the nervous tissues produce an initial stage of increased excitability. Precisely what the nature of this excitement is in every case cannot be determined. It may be very different in different cases. Excitement may be due to several causes: to normal stimulation, to resistance of the cell to foreign substances, to the paralysis of inhibitory functions of the cell, to a release of the cell by the paralysis of controlling cells. We can no longer think of a nerve cell as a simple 


\section{PSYCHOLOGY OF INTEMPERANCE}

structure performing one or two functions. It is exceedingly complex, and performs many functions.

To enter into the problems of the physiological effects of alcohol is to come upon a maze of contradictory opinion and pending conclusions from experiment and observation. Yet some important facts seem to be established. Recent biology has thrown some light at least upon the general relation of alcohol to animal life. Ethyl alcohol, the basis of all alcoholic intoxicants, is the product of the yeast plant, acting in a saccharine substance. The yeast plant belongs to the lowest sub-kingdom of plant life, and is classified as a fungus. It has neither root, stem, nor leaf, and contains no chlorophyll. It is unable, therefore, to subsist upon simple, inert compounds like other plants; and so, like animals, it depends upon organisms containing chlorophyll for its food. Its energy is obtained through a decomposition process, and in this process dextrose is broken up into ethyl alcohol and carbon dioxide. These products are both excretions, for the yeast plant makes no use of them. The law seems to be fully established that all excretions are toxic or poisonous to the organisms that produce them, and to all other organisms higher in the scale. Ethyl alcohol, then, if this be true, is essentially a poison to animal life; but we still are 
ignorant of the obscure effects of excretions upon the tissues $\left({ }^{48}{ }^{49}\right)$.

Problems of the general physiology of alcohol are of less moment for a psychological study of intemperance than might at first appear to be the case. The essential fact for psychology is that this substance causes a certain order of mental effects. The physical nature of the effects must be known, it is true, before we can fully understand the problem, but the mental states themselves are the central effects sought, and these are what they are whatever the physical basis of them may be. The place of alcohol in evolution is not determined by discovering to what extent it may be a poison or a food.

The course of physiological discovery has been decidedly toward the conclusion that alcohol in any considerable quantity is a deleterious substance in the body. The controversy still continues in regard to its food value, but at present the weight of evidence is strongly against the inclusion of alcohol among true foods. At most it can be said to be oxidised in the body, and to create heat and possibly supply energy for muscular activity; acting as Starke says, like the carbohydrates, but without the power of building up tissues. Starke perhaps stands alone in his entire denial that alcohol, even in large quantities, is harmful to the body, maintaining that its effects are quite 


\section{PSYCHOLOGY OF INTEMPERANCE}

within the range of normal play of function, and are not to be called disturbance; and that it is only in extreme cases of excess that we can speak of poisoning by alcohol-and then only as any food substance may become a poison $\left({ }^{50}\right)$.

Others maintain that alcohol is a selective poison: that it acts chiefly upon the cells of the blood, and upon the walls of the vessels through which the blood circulates; that the white cells of the blood, which are very similar to an amœba in structure, and perform important functions in the body, are irritated and paralysed by alcohol. On the basis of recent experiments, for example Hunt's, it is asserted that oxidation of alcohol in the body which results in heat, is a protective oxidation; and in these experiments it was found that alcohol taxed the oxidation capacity of the liver, and left the organism defenceless against bacterial and other toxic substances $\left({ }^{51}\right)$.

The deleterious effects of alcohol in large quantities, or from constant use for long periods, seem undoubted, although there are wide variations of opinion about the quantity of alcohol necessary to produce permanent changes in tissues. It seems clear that alcohol can cause serious disease of the brain, the spinal cord, and the nerves, in persons of previously normal constitution; that chronic alcoholism lowers resistance to many infectious diseases; and that 
the effect of liquors is not due to adulterations in them, as some claim, but to the ethyl alcohol itself $\left({ }^{52}\right)$.

Experimental study of the effects of alcohol and other stimulant-narcotics upon the mental and the physiological processes of man, notwithstanding much work that has been done, is still at the beginning, rather than the end of its work. There are many problems to be worked out, some of them exceedingly intricate, requiring a minute and tedious experimentation, and difficult analyses. It might seem to one unfamiliar with such experiments, that it would be an easy matter, for example, to determine what the effect of a given dose of alcohol is upon the strength of a group of muscles, but such is not the case. Many causes are at work at all times affecting the conditions of muscles and nerves, and an apparently simple movement is in reality very complex, and sometimes difficult to measure.

Many experiments have been made to determine the effect of small doses of alcohol upon various mental and physiological processes. Exact investigation of the problem appears to have begun with Kräpelin's study of the effects of alcohol upon the reaction time; that is, the time between the receipt of an expected signal and the quickest possible voluntary response. He used doses of from 25 to 60 grams, 


\section{PSYCHOLOGY OF INTEMPERANCE}

tested four subjects, and found that under the influence of small doses the reaction time was shortened, and increasingly so with an increase of the dose up to a certain limit. The shortening of the time began to appear within five minutes after the alcohol was taken, and the quickening effect continued to increase during the first twenty minutes. With a larger dose the reaction time was either lengthened or the period of increased speed was shortened. In all but two instances in which there was an initial shortening of the time there occurred later a lengthening of the time beyond the normal.

Other experiments, made by various writers, confirm these conclusions in a general way. It seems certain that small doses of alcohol temporarily quicken reaction time, that larger doses lengthen it almost if not quite from the start, and also that small doses cause, as an aftereffect, a lengthening of the time.

Experiments made to measure the effect of small doses of alcohol upon muscular power show results similar to those for reaction times. Lombard found that the taking of whisky or claret was always followed by increase in the muscular power as measured by the ergograph - an instrument by which the power of a single muscle (or small group of muscles) to make contractions is measured. In his case no depressing after-effects were noticed. But us- 


\section{MENTAL AND PHYSICAL EFFECTS 91}

ually in such experiments the depression has been readily detected. Destrée, for example, found an increase in the muscular power occurring from one to two minutes after the taking of alcohol. This increase lasted from 10 to 30 minutes. Then power began to decline, and was soon less than normal. The larger the dose of alcohol the more rapid was the onset of the depression, and the longer its continuance. Lieutenant Boy of the Swedish army made tests of the ability of soldiers to shoot with the rifle and the revolver, with and without moderate doses of alcohol, and found that the results were always in favour of the abstainers. Schneider compared work done on the ergograph after fasting, after taking a concentrated food, and after taking Bordeaux wine. He found improvement throughout after taking food, and as a result of the alcohol a slight increase at the beginning, followed by a decrease. Mayer experimented upon writing at speed, and found a retardation as the result of taking alcohol, the falling off increasing with the quantity of the alcohol taken. Kuertz made tests of the rapidity of adding, giving alcohol in the evening before the day of experiment, and found a loss of from 3\% to $15 \%$ from the normal rate, with also a cumulative effect $\left({ }^{53}\right)$. Other experiments have given the same general result. 


\section{PSYCHOLOGY OF INTEMPERANCE}

In order to test a practical movement, one like the movements of actual work, the writer undertook to estimate the effect of small doses of alcohol upon the power to make at short intervals, for considerably long periods, the maximal hand-clasp $\left({ }^{54}\right)$. This movement is known to be correlated, in strength, with other muscular powers of the body, and to be a good test of muscular power and condition in general. The apparatus used was a spring dynamometer. It was attached horizontally to a table, and was so arranged that every movement made by the hand was recorded upon a revolving drum, while at the same time an endless tape computed the total length of the movement, a quantity from which the power in pounds was easily estimated. In testing, one hundred maximal contractions were made at intervals of 1.6 seconds, a metronome indicating the rhythm. The remainder of a tenminute period was spent in rest. This "round" was then repeated, and so on until six "rounds" were completed, making an hour's work. Now by alternating days in which alcohol was taken and days in which none was taken, or inserting alcohol days at other regular intervals in a normal series, there was a means of determining the effect of the alcohol upon the work. The details of preliminary experimenting, the precautions to eliminate errors, and the mathe- 


\section{MENTAL AND PHYSICAL EFFECTS 93}

matical methods used in computing results, how various disturbing factors, such as fatigue, were eliminated and the effect of the alcohol itself was measured, need not be told in detail. It is sufficient to say that by comparing the two series of days it was possible to measure the effect of the alcohol upon the muscular ability, at least with a high degree of probability of having obtained correct results.

Two persons were experimented upon. One subject worked two hours each day for thirteen days. On some of the days he took, both morning and evening, just before beginning the work, 60 grams of a $331 / 3 \%$ alcohol. In this case the effect of the alcohol upon both morning and evening work was slightly to lessen the amount done. No stimulating effect whatever was found, the alcohol appearing to counteract the effect of warming up which usually made the second round better than the first.

In the second case effects of alcohol were found to be much the same as those determined by other experimenters, working with other processes. Forty-five grams of the $331 / 3 \%$ alcohol had the effect of slightly increasing the quantity of work done during the hour, with apparently an increasing effect while the work was continued. But this stimulating effect was very slight, so small as to be negligible, at least from a practical point of view. 


\section{PSYCHOLOGY OF INTEMPERANCE}

In another series of experiments, continued for a longer time, and done under better conditions, 90 grams of the alcohol were used. Still there was no certain effect upon the quantity of the work done during the hour, but there was a decided effect upon the distribution of the work. During the first half hour the amount of work done was increased by the alcohol, and during the last half hour it was diminished, the excess in one case exactly balancing the deficiency in the other; the precision of this result, however, having little significance. The greatest beneficial effect occurred during the second round, when the work done with alcohol was about $4 \%$ greater in amount than the normal work.

The effect of the alcohol was tested in still another way. The ability to accomplish work upon the dynamometer during the second hour after taking the alcohol was measured. No muscular work was done during the first hour, but tests were made as before during the second hour, except that fifty instead of one hundred contractions were made. Here too the effect, though slight, seemed unmistakable. Less work was done during each round on the alcohol days than on the normal days, showing that a slight depressing effect of the alcohol remained over at least until the end of the second hour. This depression was greatest during the 


\section{MENTAL AND PHYSICAL EFFECTS 95}

third round, that is, an hour and a half after the taking of the alcohol.

On the whole, the evidence, both from our own experiments and from those of others, decidedly leads to the conclusion that the effect of relatively small doses of alcohol upon various motor abilities of man is to increase power and rapidity slightly for a short time, varying with the amount of the alcohol (and probably with the temperament of the subject) and then to diminish it. That there may be so slight a stimulation that no depression follows, and that increase in the amount of the dose above a certain limit shortens the period of stimulation, or obliterates it altogether seems proved, also. Though these are effects commonly noted, we must allow for the probability that there are some individuals who are not thus typically affected by the alcohol, for example the subject of the first of my own experiments. But the mass of evidence, taken as a whole, presents a clear picture, which must be accepted as reliable. That the stimulating effect is upon the nervous tissues and not upon the muscle involved in the activity is shown by the experiments of Lombard, who found that the muscular response to electrical stimulation was always diminished by the alcohol, while the ability to work under voluntary stimulation was actually increased. 
The effect of small doses of alcohol upon the rapidity and other qualities of such typical mental work as adding of digits, reading, and the like has been studied experimentally, but with less definiteness and less agreement in the results. These mental processes are more complex than the motor functions that have been experimented upon, more variable from one individual to another, and therefore are not so easily measured with precision. The early experiments made upon mental processes seemed conclusive on one point at least. No very large quantity of alcohol can be taken without lessening the amount of mental work, and causing its quality to deteriorate. Whether there is an initial period of stimulation was not so clearly made out. Some of Kräpelin's experiments seemed to show that there is, but he himself concluded that it is the motor process connected with the mental which is stimulated, that the effect of the alcohol upon the sensory functions is always a depression; and that, in a mixed process, the greater the proportion of the sensory element, the greater the liability to depression rather than stimulation.

Some experiments of my own do not agree with the results of Kräpelin, yet they do not conclusively refute the statement that the sensory processes do not undergo a period of initial stimulation. Mixed processes, that is, proc- 


\section{MENTAL AND PHYSICAL EFFECTS 97}

esses in part sensory, partly central, and in part motor were experimented upon. Adding, reading, and writing were tested, in order to measure the effect of small doses of alcohol upon the rapidity and quality of these typical practical functions. The work was continued for two hours each day, in periods somewhat similar to those used in the motor tests. On certain days alcohol was taken five minutes before the work began. In all cases some slight stimulation was found to have been produced by the alcohol. In adding, the quantity was increased slightly both for the first and the second hour. In reading there was a slight improvement on the alcohol days for the first hour, and a slight depression during the second hour. In writing, there was stimulation during the first hour, and depression in the second. These changes were all slight, and the precise length of the period of stimulation was not determined. Study of the relation between work of adding columns of digits and reading the same digits without adding seems to show that the effect upon the sensory and central processes alone was a stimulation quite as great and quite as prolonged as upon the motor processes. But we are dealing with small numerical quantities, and there are many chances of complicating the results by irrelevant factors-so the question of the effect of small doses of alcohol upon 
purely sensory processes, if such can be determined, must be left open.

These experiments give us a picture of what may be called an intoxication of the nervous system in a mild form. So far as that picture can be said to be typical, it is this: At first there is stimulation of energies, and then depression. The effect is to make work more variable, to break up the monotony and even flow of activity. Other experiments, such as those made upon the association of ideas, gave similar results. Not only is the association time made more variable, but irregularity in the character of the mental sequences seems to be produced by the alcohol.*

The experiments upon alcohol may be said to prove conclusively that no measurable quality. of either mental or physical work is as such improved to any practical extent by alcohol. This conclusion is strikingly in contrast with widespread popular opinion, which has always maintained that alcohol assists both mind and body. It is interesting and significant that the

* The experimental investigations of the effects of alcohol have recently been summed up by M. A. and A. J. Rosanoff, with the statement that alcohol impairs every human faculty that has been tested; that the higher and more complex the faculty the more pronounced is the effect upon it; that the effects of alcohol are cumulative, and continuous use, even in small quantities, impairs the faculties at a rapidly increasing rate $(55)$. 


\section{MENTAL AND PHYSICAL EFFECTS' 99}

effect is upon the feeling of power rather than upon the energies themselves. Alcohol causes changes in the intensity of consciousness; and this more than anything else is the secret of its influence. 


\section{CHAPTER VII}

\section{THE STATE OF INTOXICATION}

There are many interesting accounts of the mental effects of various intoxicating drugs,

some to be found in popular writings. De Quincey's Confessions of an English Opium Eater set the fashion for this kind of study, and also unfortunately popularised the use of opium by writers and others to stimulate the feelings and the imagination. Although the descriptions of intoxication that have thus been inspired are sometimes exaggerated, their points of general agreement must be given due weight. Experimental studies of drug intoxications have been made, which will help to correct the more popular accounts. Weir-Mitchell, Prentiss and Morgan, Delabarre and others have contributed careful studies. Delabarre says that after taking hasheesh one gets a larger conception of the range of the emotional life. Frequently mentioned effects of drugs are the awakening of early memories, exaggeration of emotional states, changes in time and space perceptions (commonly referred to as a feeling of infinity), fantastic colour visions, confusion of hearing 


\section{THE STATE OF INTOXICATION "101}

and vision, animistic beliefs, philosophic insight, double personality, sensations of extension of the body, increase of personality. All this shows that a wider range of mental functioning is going on (whether as a result of paralysis of control or stimulation of nerve cells directly) than in the normal condition. It is the common testimony that the normal limits both of pain and pleasure are passed. And the conclusion which applies to nearly if not quite all the cases that have been examined, is that the intoxication is essentially a succession of emotional states, or changes, in which exhilaration, accompanied by a free flow of thought and heightened sensibility, is followed by depression, decreased associative power, and lessened sensibility. $\left({ }^{56}\right)$

Compared with the other intoxications the alcoholic appears to have characteristics peculiar to itself, and in some ways to be similar to others. The effects of alcohol differ greatly with temperament, conditions under which the drug is taken, and with the ingredients with which it is mixed. The mood in which intoxication is begun, the stimulus received during the intoxication, and various preceding mental and physical conditions all seem to affect its course.

In order to eliminate so far as possible many irrelevant and variable factors, and to study 


\section{PSYCHOLOGY OF INTEMPERANCE}

certain standard or typical effects of large doses of alcohol, the writer made experiments upon four subjects under laboratory conditions. In this way the exact amount and character of the intoxicant administered could be known, and be made uniform for all subjects, and other conditions could be controlled. The history of each subject could be ascertained, and it was possible to take into account many facts of individual differences.

The subjects were all mature students, and none had ever used alcohol as a beverage-all were practically total abstainers. To produce intoxication, 600 grams of $16 \% 3 \%$ alcohol were administered in six doses, at intervals of half an hour. Experiments upon mental and physical functions were carried on during the whole course of the intoxication. The details of these experiments will not be given here, but the main results may be briefly mentioned. Until the intoxication was well advanced, the rapidity of performing common mental processes was not much affected. Adding, memory for nine-place figures, estimates of distance and time, clearness of vision, were not seriously interfered with until there was a very pronounced degree of muscular inco-ordination. The strength of the hand-clasp, and the rapidity of performing a tapping movement with the finger, were also comparatively little affected, the 


\section{THE STATE OF INTOXICATION 103}

tapping rate, however, showing more depression than the other activities. In general the effect upon all these processes seemed to come largely through an emotional change; the subject became indifferent and relaxed effort or tried to be annoying.

An experiment made to test the control of a reflex action, showed peculiar changes in the mental state, even in the earlier stages of intoxication. In this test the ability of the subject to control the reflex wink of the eyelids, when the eye was threatened by a blow, was measured. A simple piece of apparatus was used. The subject sat behind a glass plate, which was struck at regular intervals by a hammer released from the tension of a spring. The three subjects who were tested were affected alike by the alcohol. LAll controlled this movement very much better after taking alcohol than when in the normal condition. This was somewhat surprising, for one of the most frequently mentioned effects of alcohol is an increase of difficulty in controlling movements. But it was soon seen that the reason for this effect was a changed emotional state, which began to appear very soon after the alcohol had been taken. A feeling of confidence was induced, which gradually deepened into recklessness and bravado. Alertness to the conditions of the environment was lessened, so that while there was ap- 


\section{PSYCHOLOGY OF INTEMPERANCE}

parently no diminution of sensibility sufficient to account for the effect, a mood was aroused in which response to such stimuli as the threatening of the eye was better controlled. This mood was shown in other ways. One subject, who was very precise and exact when in his normal condition, and who during the first two rounds of the experiments, before the effect of the alcohol was felt, was careful to observe all the conditions in the minutest detail, now began to disregard the directions, until finally he insisted upon doing the experiments in a way of his own, not at all to the liking of the experimenter.

In all the cases intoxication followed much the same course. An initial stage of excitement and increased, activity, accompanied by a feeling of pleasure, 'was followed by a stage of depression, with displeasure. In two cases a second period of exhilaration followed the first depression, but on a lower plane and not so prolonged: a second intoxication, caused it is quite likely by the later doses of alcohol, but showing clearly that it was but a feeble arousal of activities already partially demoralised. In each case there was a peculiar, clearly defined moment when there was a feeling that control was in some way being lost, and with it a desire to throw off all restraint, and give way completely to the feelings. One subject described a 


\section{THE STATE OF INTOXICATION 105}

moment in which he felt that he could control the intoxication or allow it to go on, but that if this moment should pass without a strong effort at control, the condition would then be beyond his command. Another subject announced at one stage of the intoxication that if he should swing his arm about two or three times (illustrating, evidently with care not to let go) he would be "done for." What this moment signifies is not clear, but that control functions of some kind have become weakened and are now on the point of giving way seems evident; inhibitions, the breaking down of which we may suppose allows parts of the nervous mechanisms to come into play that are not used in ordinary experiences.

All the subjects passed through a series of moods which seemed to determine the character of their thoughts. This is best shown by the association tests which were made at intervals during the course of the intoxication. A list of four hundred words was read to each subject two weeks before the day of his experiment. To each word as pronounced he was directed to respond with the first word or idea that came clearly to mind, allowing the mind to remain entirely lax. While the intoxication was in progress the same list was read again, divided into groups of fifty words, the same type of response being called for as before. The result 


\section{PSYCHOLOGY OF INTEMPERANCE}

of the alcohol was to produce an increasing number of reactions different from those of the normal reaction, with a gradual return to the normal type as the effects of the alcohol wore off. These associations show in a remarkable manner the moods which caused them. As intoxication increases, the incisive, one-word response begins to give place to the more indefinite and loose response. Soon the answers become discursive, until at the height of the intoxication the subject wishes to make a speech about each word. This discursive reaction persists while the mood changes from elation to depression and melancholy, and through a second period of elation likely to be maudlin in character. Gradually the normal type returns with an occasional relapse to the intoxication type. All subjects were conscious, in retrospect, of having tried in the early stages to be humorous, or of willingly giving way to humorous thoughts. In one case, a subject had a preconceived theory that intoxication is due largely to suggestion; that if one drinks with the intention of remaining serious and sober, there will be little intoxication. The report, made in retrospect, was that during the first half hour there was little change in feeling, but that finally there arose a desire to make witty remarks, and at the same time the reflection that to give way to the feeling would mean to 


\section{THE STATE OF INTOXICATION 107}

encourage intoxication, and disprove the theory. This impulse to communicate witty thoughts, which came thicker and faster, finally became so strong that the subject could not resist the temptation to tell one that seemed especially humorous. But no sooner was one thought spoken aloud than another came, still funnier than the first, with the thought that this one would be allowed, and then no more. So it went on for two hours, one remark suggesting another, until the mood changed, and melancholy ensued, though this stage was short in this case. All the time the belief continued that the state of mind could be controlled, and that the decision to tell what was in the mind was a voluntary choice. In this case alone of the four, there was little physical depression, and no feeling of nausea; correspondingly, it seemed, no marked melancholy, and quick return to normal condition.

The results of these experiments can perhaps be made clearer to the reader by reporting in detail one case.

\section{A Case of Intoxication}

The subject of the experiment about to be reported was a man of thirty-five years, serious and dignified in temperament, a specialist in education, his main work having been teaching and administration. He was in perfect health, 


\section{PSYCHOLOGY OF INTEMPERANCE}

of muscular habit, and active both mentally and physically. He was entirely unaccustomed to the use of alcohol, and undertook the experiment because of its scientific interest, to have the experience, and in order to know what an intoxicated person feels.

The place of the experiment was a large room of a laboratory, with special apparatus and tables for these tests arranged in one part. Only the experimenter and the subject, and during a part of the time, an assistant, were present. All social excitement was eliminated, and the seriousness and quiet of the scientific laboratory were maintained. The alcohol was administered in divided doses, and was a $162-3 \%$ solution of absolute alcohol and distilled water. Six doses of this mixture, 100 c.c. in each dose, were prepared, but only five were given. The doses were administered at $2: 55,3: 26,4: 05,4: 48$, and $5: 55$ р. м. The sixth dose was not given for the reason that the subject was at the time argumentative, and refused to take it. Between the doses various experiments were carried on, and were continued until recovery from the effects of the alcohol at about $9: 00$ P. м.

The earlier series of tests will be mentioned presently, but first the results of the association test (described in the preceding section) will be given. This was carried on from about 4:00 


\section{THE STATE OF INTOXICATION 109}

P. M. until 9:00 P.M., somewhat irregularly owing to the difficulty in keeping the subject at work in the routine which was previously planned. Recently much attention has been given to the association test as a method of mental diagnosis, and it has been used for various purposes, such as the analysis of mental disorders, determination of mental type, and detection of crime. Below is given the complete list of the words and the reactions. The first column contains the test words; the second is the list of normal reactions, made two weeks previous to the day of the intoxication experiment; and the third column contains the words given by the subject during the stages of intoxication.

TABLE SHOWING EFFECT OF ALCOHOL UPON ASSOCIATIONS

$\begin{array}{lll}\text { TEST WORD } & \text { NORMAL REACTION } & \text { REACTION AFTER ALCOHOL } \\ 1 \text { name } & \text { man } & \text { P- } \\ 2 \text { glass } & \text { crystal } & \text { window } \\ 3 \text { accident } & \text { injury } & \text { suffering } \\ 4 \text { home } & \text { mother } & \text { mother } \\ 5 \text { virtue } & \text { vice } & \text { vice } \\ 6 \text { boy } & \text { girl } & \text { girl } \\ 7 \text { independent } & \text { gervility } & \text { non-conformity } \\ 8 \text { tranşcendental } & \text { real } & \text { out of experience } \\ 9 \text { drunk } & \text { sober } & \text { sober } \\ 10 \text { happiness } & \text { contentment } & \text { peace } \\ 11 \text { gate } & \text { somebody walking } & \text { manner of walking } \\ 12 \text { hall } & \text { G. S } & \text { G. S- } \\ 13 \text { manners } & \text { good breeding } & \text { good behaviour } \\ 14 \text { success } & \text { failure } & \text { failure } \\ 15 \text { salvation } & \text { damnation } & \text { sin } \\ 16 \text { iron } & \text { screw } & \text { jack-knife } \\ 17 \text { city } & \text { country } & \text { town } \\ 18 \text { telegraph } & \text { message } & \text { message } \\ 19 \text { temperance } & \text { moderation } & \text { non-alcoholism } \\ 20 \text { doctor } & \text { patient } & \text { H- }\end{array}$




\section{PSYCHOLOGY OF INTEMPERANCE}

TEST WORD

\section{1 bottle \\ 22 cat \\ 23 cart \\ 24 high \\ 25 paste}

26 tin

27 history

28 summer

29 horse

$30 \mathrm{key}$

31 sickness

32 hope

33 heaven

34 box

35 battery

36 banner

37 Spaniard

38 watch

39 pride

40 window

41 torpedo

42 widow

43 jealousy

44 post

45 zylol

46 girl

47 carriage

48 tissue

49 emotion

50 conventionality

51 varicosity

52 justice

53 fear

54 experiment

55 favor

56 knife

57 tin

58 paper

59 Renaissance

60 table

61 screw

62 clock

63 obedience

64 instrument

65 murder

66 travel

67 psychology
NORMAL REACTION

whisky

dog

wheel

low

adhesiveness

pan

poetry

winter

rider,

lock

health

despair

earth

wood

shock

flag

Portuguese

time

haughtiness

pane

explosion

funeral

quarrel

nail

preserving fluid

boy

horse

strength

feeling

formality

enlargement

equality

love

correctness

help

cutting

can

writing

bloodshed

chair

iron

time

love

implement

bloodshed

experience

experiments
REACTION AFTER ALCOHOL

whisky

dog

horse

low

mucilage

rocks

poetry

winter

rider

lock

health

despair

earth

wood

shock

flag

Cuban

clock

haughtiness

glass

boat

funeral

anger

fence

preserving fluid

boy

horse

cells

feeling

formality

enlargement

mercy

anger

reslity

gratitude

whittling

rocks

letter

bloodshed

chsir

iron

time

goodness

utility

bloodshed

new experienco

experiments 


\section{THE STATE OF INTOXICATION 111}

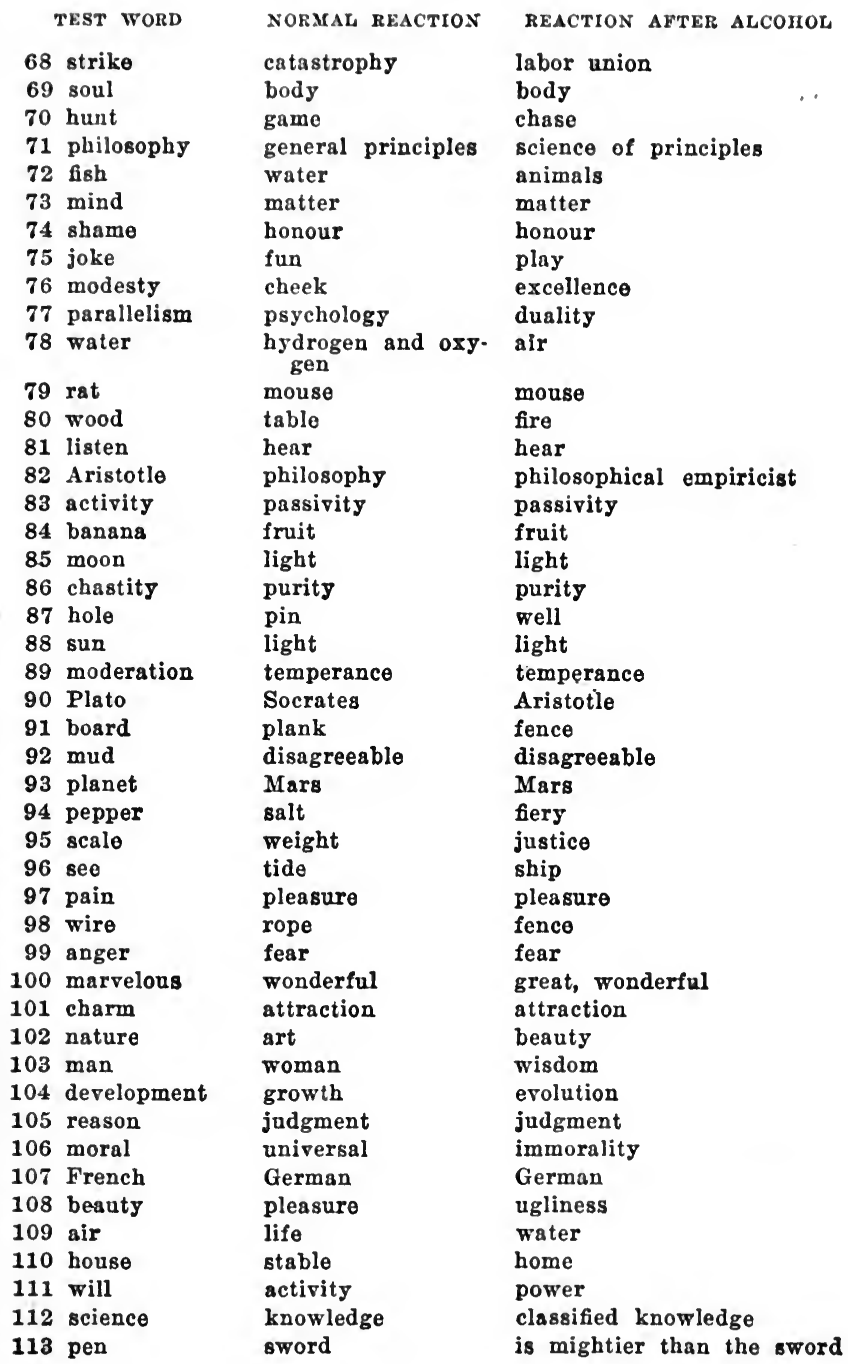




\section{PSYCHOLOGY OF INTEMPERANCE}

TEST WORD

114 kind
115 good
116 savage
117 true
118 luck
119 love
120 whiskers
121 whe
122 game
123 deceit
124 pocket-book
125 insurance
126 stimulus
127 scissors
128 Goethe
129 brain
130 devil
131 helpless
132 alert
133 beautiful
134 diligent
135 jail
136 paraffine
137 injustice
138 calculus
139 weak
140 humanity
141 animal
142 pleasure
143 wealth
144 economy
145 species

146 nightingale

147 Rossetti

148 church

149 prince

150 tobacco

151 year

152 muscle

153 flower
NORMAL REACTION

consciousness of evil

civilised

false

chance

hate

breezes

play

treachery

rocks

life

exertion

cutting

poetry

mind

God

just helpless (vis- helpful-I'm full, too ual)

active

comely

successful

see one

wax

justice

mathematics

strong

inhumanity

man

pain

poverty

meagerness

genus

music

Dante Gabriel

preaching

king

smoke

1898

strength

leaf
REACTION AFTER ALCOHOL

conscionsness of

bad and indifferent

barbarous

false

there isn't any

war

breezes

sport

lying

blank in my case

safety

reaction

cutting

poet

anatomy, psychological reaction

God

quick at reaction

lovely

successful

shut up for a while

protective

justice

mathematics

go where you please

inhumanity

$\operatorname{man}$

good as far as it goes

influence

political economy

genus, genera, that's the plural, now don't you sce?

bird that comes when spring comes on

what the fellow saw when he was jimjams; saw Rossetti on a jack-rabbit place of worship

Prince of Wales

smoke

twelve months, nothing more strength; when a man is on his muscle folks have to look out for him (im. plied threat)

corn.meal 


\section{THE STATE OF INTOXICATION 113}

TEST WORD

\section{American}

155 Dante

156 chance

157 old

158 Quaker

159 music

160 righteousness

161 incline

162 horror

163 blue

164 discovery

165 rope

166 radical

167 Romeo

$168 \mathrm{rabbi}$

169 imagination

170 kymograph

171 sweet

172 capacity

173 cup

174 art

175 one

176 mind cure

177 electricity
NORMAL REACTION

Spanish

Inferno

luck

young

H. G-

Beethoven

unrighteousness

to slope

fear

blazes

America

halter

conservative

Juliet

Ben Levi

phantasy

record curve

sour

extension, measure

glass'

science

victory

faith cure

shock

\section{REACTION AFTER ALCOHOL}

Spanish

Inferno. Old man had pretty good ideas of things sometimes, didn't he?

lnck

young

Friend, here's the gentleman; preaches on war

music is art-osthetics appeal to man's highest nature

thing that people ought to cultivate

makes me think of the slow pup

kind of fear that makes the hair stand on end

I'm never blue

Columbus made a big one

that's the thing they make those peculiar neckties of

if you want to be brief, conservatism is a good antithesis

\section{Juliet}

Jewish priest

that's what you and most scientists don't have

that's one of those things that makes records

0 , probably certain rooms adjacent to one another

that's what you do not possess, sir. At the present time I don't think I possess a great deal more to hold the $O$ be joyful you administer in $162 / 3 \%$ doses

that's intoxicating cup. Seems to me I get a French accent on these things. $\mathrm{P}-\mathrm{comes}$ floating into my head (he was right about the French accent)

0 , art is ze most beautiful expression ze human soul aspires to

why, two, sir

$O \underset{\text { mind cure }}{\mathrm{G}}$ is the apostle of produces a shock, sir 


\section{PSYCHOLOGY OF INTEMPERANCE}

TEST WORD

178 rapture

179 suggestion

180 reflection

181 arms

\section{2 free}

183 imitation

184 diary

185 amused

(6:15 P. M.)

186 solitude

187 nerve

188 drum

189 piety

190 disappointed

191 resemblance

192 jury
NORMAL REACTION

extreme pleasure

reaction

judgment

man waving arms

\section{generous}

following others

daily record

just the word

society

cheek

curve

temperance

regretful

likeness

judge
REACTION AFTER ALCOHOL

0 , that was exceeding joy. But if you wrapped yourself round with a horse blanket, you might be a jackass.

connected in a definite way with hypnotism

is the thing that makes a man himself

well, if you were a poor man benefactions people give you. If you are a rich man the means by which you are enabled to administer to your physical wants

makes a man independent of any restrictions

simply doing as other people do without regarding the primitive impulse to assert himself as himself

where a man keeps a record of things as they occur

$I ' m$ amused at the seriousness with which you take down all these matters which occur after split and I have come iuto immediate contact

there's no such thing, sir

beard a good many people call it cheek. You would embody a higher exempli. fication of it than any. one I know

noise, boys like that, you know

involves so much a man can't express it brieflyheard about the pious Aneas-careful to fulfil every pious duty-in the highest sense makes a man true to every principle that moves his being - the highest instinct

something I never was likeness

is supposed to stand for justice-a body of men at the mercy of one who can make the best soultouching argument 


\section{THE STATE OF INTOXICATION 115}

TEST WORD

193 error

194 culture

195 congregation

196 study

197 moral

198 adolescence

199 child

200 foot

201 education

202 eat

203 God

204 teaching

205 adult

206 conclusion

207 report

208 bibliography

209 drink

210 help

211 literature

212 life

213 danger

214 book

215 exactly

216 author

217 accidentally

218 Worcester

219 people

220 example

221 heart

222 precept

223 paper

224 pain

225 school

226 journal

227 educator
NORMAL REACTION

wrong

civilisation

collection of people

pleasure

immoral

youth

man

walking

growth

sleep

no association

education

$\operatorname{man}$

fallacious

record

collection of names

water

aid

American

indefinable

fear

slate

correctly

J. R. Lowell

unforeseen

Massachusetts

humanity

precept

ventricles

example

pen

pleasure

study

daily record

\section{REACTION AFTER ALCOHOL}

that's the thing which every human being who ever lived made to his regret

the thing that all humanity ought to aspire to. It is the best in us

nothing but a collection of individuals - you know what grex means

pleasure

worth

youth

man

yard

desirsble thing

grow

man

the best thing in the world for a man

childhood

the result of effort

may be public opinion

one of the most helpful things in the world

a curse

strength

think of all the different schools

death

safety

parchment

inexactly

work

providentially

Massachusetta

collection of individuals

precept

life

example

pen and ink

pleasure

life

daily record

our old dominie. You know the derivation, dominus master, sometimes talks through his hat, sometimes grinds people, but he's the man for the people after all 


\section{PSYCHOLOGY OF INTEMPERANCE}

TEST WORD

228 youth

229 ball

230 editorial

231 friend

- 232 ink

233 seminary

234 ache $^{\circ}$

235 pencil

236 manhood

237 beer

238 heredity

239 discussion

240 frost

241 hour

242 health

243 year

244 promise

245 fence

246 interest

247 disease

248 weight

249 answer

250 apperception

251 gold

252 insanity

253 pie

254 liberty

255 8quash

256 picture

257 saint

258 Klondike

259 seven
NORMAL REACTION

age

play

comment upon topics of the day

enemy

pen

seed sowing

pain

paper

womanhood

two per cent.

education

argument

cold

sixty minutes

happiness

twelve months

agreement

post

pleasant

weakness

avoirdupois

message

an after perception

silver

madness

cake

freedom

pumpkin

art

Anthony

misery

eight
REACTION AFTER ALCOHOL

age

baseball

supposed to be an expression of sound judgment

one of the best things a human being can have

sometimes a blot, sometimes a potent saying

place for the sowing of seed-of course I think of the Friday nights

functional derangement pen

main thing to live for

don't know what it was made for-guess it means $b-i \cdot e \cdot r$ in the end

what no man can avoid, and the pity of human conditions

sometimes a fair considerstion, sometimes sophistical word-play

increased cold

sixty minutes

sickness

1898

something that ought to be kept

something that shuts in, and also shuts out

the one thing that makes life worth living

health

gravitation

question

an after perception

silver

sanity

thing that boys cry for, and printers sigh for

the only thing that enables a man to be a man

have to think of the vine family-pumpkin

madonna

Anthony

a foolish craze-a kind of insanity

eight 


\section{THE STATE OF INTOXICATION 117}

TEST WORD

260 Boston

261 Sabbath

262 newspaper

263 dictionary

264 sheet

265 eyes

266 appetite

267 case

268 brother

269 question

270 stopple

271 sweet

272 neurosis

274 sctivity

275 curtain

276 face

277 populist

278 change

279 climate

280 yellow

281 physician

( $7: 40$ P. M.)

282 square

283 look
NORMAL REACTION

Massachusetts

Jew

reporter

Century

paper

sight

tendency to seek

hard case

sister

answer

bottle

sour

psychosis

passivity

shield

eyes

politician

instability

hot

blue

health

round

expression

\section{REACTION AFTER ALCOHOL}

Commonwealth of Massa. chusetts, the United States of America-the place that grew into prominence some years ago and in its own estr. mation has always becn important since - sup. posed to be connected with the revolutionary apparatus of the universe

day of rest

one of the things the Amer ican people have to be ashamed of

the guiding star of the common people

sheet of paper

organs of the highest sense a man possesses

what a drunkard has, but I haven't-thank the Lord for that

hard case

sister

answer

why can't you use the United States term and say "stopper"? W h y just a stopper. that's all suite-series of rooms, op. posite of sour-what you call your lady

psychosis

passivity

exclusion of light

back

kind of specimen of animated whiskers-runs to hair more than to brains -one of these old breezers

one of these things which put permanence into difficulty with reality

hot

blue

patient

round

expression (illustrated by

story) 


\section{PSYCHOLOGY OF INTEMPERANCE}

TEST WORD

\section{4 ecstasy \\ 285 chin \\ 286 type \\ 287 cheek}

288 German
289 long
290 nose
291 frank

292 rubber

293 determination will

294 arm

295 voice

296 age

Sam
NORMAL REACTION

extreme delight

representative of a pi collection

disagreeable qual- distinguishing characteris. ity

French

short

mouth

ingenuous

elasticity

hand

song

youth
REACTION AFTER ALCOHOL

place folks get into just this side the trance stage Sam, of course

tic of a gentleman named $\mathrm{P}-$

German, Frenchman

short

a smeller

honest, ingenuous, candid, open what we like to see

dam, sir-the dentist would say

pretty long word, but means will to succeed or do

why an arm is just an arm, that's all-a member of the body (mind wan. dered)

why roice, inseparably connected with speech

haven't you a dictionarylend you one-can't afford to be a hog about it

(Interruption, subject argumentative)

297 camera
298 male
299 carpet
300 vocal
301 dream
302 rebellion
303 onion
304 nervous
305 strength
306 touch
307 organ
308 ideal
309 song
$\mathbf{8 1 0}$ silver
311 silence
312 typical
313 shudder
314 overcoat
315 emotion
$\mathbf{3 1 6}$ real estate

picture
female
beater
instrumental
sleep
Civil War
leek
lacking control
weakness
taste
choir
real
dance
hemlock
gold
generally illustrat-
ing
tremor
outside garment
feeling
personal property

photographer

female

tack

instrumental

vision

Civil War

garlic and Frenchmen

prostration

power

taste

function

real

dance

hemlock

gold

generic representation

vibration

waistcoat

feeling

personal property 


\section{THE STATE OF INTOXICATION 119}

\begin{tabular}{|c|c|c|c|}
\hline & TEST WORD & NORMAL REACTION & REACTION AFTER ALCOHOL \\
\hline 317 & leg & arm & $\begin{array}{l}\text { leg of mountain-legos- } \\
\text { George Meredith do. } \\
\text { scribes in his "Egoist" }\end{array}$ \\
\hline 318 & sister & brother & brother \\
\hline 319 & feeling & will & will \\
\hline 320 & blue & red & green \\
\hline 321 & training & exerciso & discipline \\
\hline 322 & photograph & picture & likeness \\
\hline 323 & female & male & male \\
\hline 324 & timid & shrinking & daring \\
\hline 325 & silver & gold & gold \\
\hline 326 & longing & wishing & unrest \\
\hline 327 & story & poem & diversion \\
\hline 328 & preparation & getting ready & lack of preparation \\
\hline 329 & offering & gift & gift \\
\hline 330 & expression & phrase & phrase \\
\hline 331 & $\operatorname{fam} \theta$ & knowledge & notoriety \\
\hline 332 & authority & past judgment & individual statement \\
\hline 333 & speech & roice & silence \\
\hline 334 & family & father & $\begin{array}{l}\text { foundation of state and na- } \\
\text { tion }\end{array}$ \\
\hline 335 & wine & beer & beer \\
\hline 336 & excellence & goodness & worth \\
\hline 337 & passion & action & action \\
\hline 338 & existence & lifo & life \\
\hline 339 & equality & justice & justice \\
\hline 340 & noble & ignoble & excellent \\
\hline 341 & infinity & zero & unlimited \\
\hline 342 & conquest & of Mexico & of Mexico \\
\hline 343 & generous & free & liberal \\
\hline 344 & altruism & egoism & egoism \\
\hline 345 & pledge & temperance & temperance \\
\hline 346 & denial & affirmation & negation \\
\hline 347 & revival & awakening & religious \\
\hline 348 & inertia & velocity & rest \\
\hline 349 & liquor & alcoholic & split \\
\hline 350 & Persian & Medes & Arabian \\
\hline 351 & wreck & Hesperus & danger \\
\hline 352 & reform & making over & I'm going to \\
\hline 353 & society & grex & individuals \\
\hline 354 & blaze & fire & fire \\
\hline 355 & home & mother & sweet home \\
\hline 356 & ambition & earnest action & Napoleon \\
\hline 357 & being & existence & not being \\
\hline 358 & club & social & social \\
\hline 359 & immortality & immortality & immortality \\
\hline 360 & fiame & fire & fire \\
\hline
\end{tabular}


TEST WORD

361 courage
362 stubbornness
363 causality
364 motive
365 Sunday School
366 criminal
367 virtue
368 rivalry
369 luxury
370 temptation
371 right
372 control
373 loss
374 enmity
375 prayer
376 fever
377 confession
378 fluctuation
379 duty
380 soul
381 wickedness
382 restlessness
383 anxiety
384 penance
385 strike
386 fre
387 absolute
388 space
389 freside
390 wrong
391 insult

NORMAL REACTION

will

heart within obstinacy actuating impulse Bible Study moral

vice

competition

abundance

yielding

wrong

self-direction

gain

opposition

praise

heat

acknowledgment

variation

compulsion

body

sin

rest

worriment

atonement

bloodshed

smoke

utterly free

time

revery

right

injury
REACTION AFTER ALCOHOT

the will to do the thing that must be done

compliance

effectuality

reason for doing things

day school

good citizen

vice

competition

ease.

strength

wrong

lack of control

gain

hate

praise

delirium

faith

steadfastness

obligation

body

sin

rest

struggle

atonement

bloodshed

smoke

unconditioned

time

home

right

injury

The course which feeling ran during the intoxication in this case, and in general the changes made in the mind, can easily be seen in the reactions. A stage of exaltation was followed by one of seriousness and depression, and this by a return to the normal condition. But within this general movement were several minor currents. During the stage of depression there were short periods of return of the excite- 


\section{THE STATE OF INTOXICATION 121}

ment, on a lower plane; when the reactions showed a mixture of humour and pathos, and the mind wandered. During the first period of exaltation there was evidently a conscious effort to be humorous, and to be patronising to experimenter and assistant; and this exaltation of self-feeling is further shown by the increasing obstinacy of the subject, his confidence in his ability to do the experiments correctly without instructions, and his negligence of precautions usually taken in experiment, and well known by him.

This first period of obstinacy went with a mood of good feeling and exaggerated personality sense; a later period of argumentativeness had a note of depression atd irritation. What the physiological basis of these changes in feeling may be, one wauld not attempt to say with confidence. Probably the earlier doses caused excitement and then depression; the later doses temporarily reinstated the excitement, but in a different form. The associative processes had been disintegrated, and stimulus spread with great readiness from one associative group to another.

The results of some of the experimental methods applied during the intoxication in this case will show other facts about the course of the mental changes, especially during the early stages. The method of work was as follows: 
After each dose of the alcohol the subject was put through a series of experiments, including tests for rapidity of movement, adding, memory for digits, strength of hand-clasp, estimation of time and distance, control of the reflex wink. The pulse rate was also taken during each period.

Even after the association tests showed much change in the character of feeling, the ability to make rapid movements was not greatly disturbed. On the normal day on which this abiliity was tested the records were 234, 227, 222the rate for one minute. On the alcohol day, the records taken were $213,201,175,171,165$, 176.

In estimating the length of a minute, by announcing, after a signal had been rung for starting, when he thought a minute had expired, the subject made the interval much longer on the whole on the alcohol day. The normal records were, 43.4 sec., $33.0,54.6,41.4,45.0$-and on the alcohol day, $66.4,75.6,53.0,43.4,51.6$, $61.4,65.0,65.0,61.0,58.0,58.0$. The last three were taken at $6: 30$ P. M., at a time when the associations show that the mental state was one of depressed feeling.

Ability to add, tested through the first five periods of the experiment, shows little deterioration. The normal records were 130,192 , and 196 , to be compared with $150,160,156,165,141$, 
and 178 on the alcohol day. We need to be reminded, however, that such a process as adding is very complicated, and though the records may show little change, much change may have been going on in the manner in which the work was done. Rapidity depends in part upon willingness to take chances of error, and this would counteract to some extent depression of the physiological processes concerned in the activity.

In the test upon control of the reflex wink, a very great difference was observed, in this subject, on comparing normal and alcohol records. On the normal day there was much trouble in controlling the reflex. In the first twenty-five trials, but five were controlled; and in the second series, fifteen. On the alcohol day, in the first series of trials, all but the first and the seventh were controlled, and during all the other tests throughout the whole series there was no tendency whatever to wink. At 7:05 P. M., when muscular co-ordination was much interfered with, a series of tests of the winking reflex was made, and control was perfect. The subject in retrospect said his feeling was one of indifference. He knew the glass was thick enough to keep the hammer from breaking through, and so he gave the experiment no thought. The same indifference was shown for a long period to all the experiments. When 


\section{PSYCHOLOGY OF INTEMPERANCE}

the obstinacy of the subject made the control of the conditions difficult, and he was told that unless he were more careful he would spoil our records, he replied that that was no concern of his. His attitude was then that of one who tries to tease and annoy by obstinacy.

The pulse rate, whenever taken during the intoxication, showed a rate in excess of the normal. Three countings on normal days gave 77, 77, and 78. At intervals from 3:00 P. M. to $6: 30 \mathrm{P}$. M. on the intoxication day the rate was taken with these results-92, 87, 90, 86, 92, 93. The last-mentioned record was taken at $6: 30$ during a time of physiological depression. At $7: 30$ P. M. the pulse still stood at 88 .

A few notes of many taken during the course of the experiment, or later from restrospection of the subject will show something of his attitude toward the condition.

3:26 P. M. The subject reported that he did not notice the burning sensation so much in taking the second dose, as he did in the first; showing some diminution of sensibility.

4:00 P. M. During the third round the subject was conscious in the tapping experiment of putting on more power than in the preceding rounds, and of a slower movement. This was true, and as the experiment progressed, the movement was changed from a precise finger and wrist movement to a movement of the whole body.

4:00 P. M. Muscle sensations seemed much changed. The subject lifted a chair and was surprised to find it so light, and a little later a stool, and was surprised to find it so heavy.

4:20 P. M. Complained of many body sensations. Felt as 


\section{THE STATE OF INTOXICATION 125}

though the body were long and the legs short. The neck felt less sensitive when touched by the fingers. The subject was conscious of a peculiar feeling in the legs as though they wished to straighten out rigid and firm, and to swing like pendulums from the hip instead of bending at the knee. If the eyes were closed there was a feeling of dizziness. The subject was conscious of a tendency to repeat phrases.

$4: 48$ P. M. Beginning of the fourth round. The subject complained of a feeling of numbness. He could not taste the alcohol at all this time. When he wiped his mouth he did not feel it. In the dynamometer test he tried to change to the left hand at the sixth pull. He showed signs of fatigue during the adding, and complained that everything felt gone from him. He began to show lack of interest in the experiments. When he finished the memory tests, he said, "Got in an extra one, but never mind." Instead of putting down the nine which were read to him, he had recorded ten, a gross error in a simple memory test.

6:30 P. M. The subject said that everything looked distant, but he thought he could estimate distance correctly. He tried, and did. Everything looked topsy-turvy to him, but he was not dizzy.

6:40 P. M. The subject said that he felt paralysed. A moment later he complained that the world seemed all shut in; that there was no light outside the room. There was a peculiar kind of contentment; he was perfectly content to sit still.

6:45 P. M. The subject tried to walk, and thought he could "do better at a waltz." He tried it. About this time he complained that when sitting he felt a tendency to plunge forward as though "everything were in the head."

6:55. The subject complained that he cared for nothing, whether he were dead or alive-heaven or hell, happiness or misery were all the same to him.

$7: 50$ P. M. The subject said he felt all right, so far as he felt anything. He felt as though he had been asleep. He was conscious that he had been talking wrong, pronouncing everything in the easiest way.

7:50 P. M. The subject said that his words still sounded 


\section{PSYCHOLOGY, OF INTEMPERANCE}

different to him, both in expression and in tone, from the normal. He said that now in looking back he could see that concentration of his attention upon a motor task had had an effect of bringing consciousness together and clearing it.

$7: 55$ P. M. The subject seemed quite sober. He still walked with slight inco-ordination. He guessed the time of day correctly. He complained still of a numbness all over, as though he were not a living organism. Since the last dose the time had seemed very short, as though sometime in the past he had been shut up like a book. He remembered that he had passed through a compliant stage, and an argumentative stage.

8:30 P. M. The subject said that since the beginning of the fifth round everything seemed a blank. The world seemed small and shut in. He still felt a desire to look into a mirror to see whether he were really swaying in sitting upright, or whether this were merely a sensation. It was mostly subjective.

These facts about the effect of alcohol and other stimulant-narcotics suggest some conclusions that seem quite secure, and they also open up tantalising problems of physiology and psychology upon which at present scarcely more than conjecture may be offered. The evidence, though not entirely without contradiction at some points, or at least not without allowance for individual differences, seems to warrant the assertion that all these stimulants and narcotics, in intoxicating as in small doses, excite for a short period, and then depress or paralyse, the functions or activities of whatever nervous tissue they affect. In some cases the period of excitation may be brief or obscure, but the 


\section{THE STATE OF INTOXICATION 127}

typical mode of action of these drugs is at first to arouse activity.

A second quite obvious conclusion is that nervous mechanisms or tissues are not all equally affected by stimulant-narcotics. They are affected progressively, one function after another being reached. A quantity sufficient to paralyse completely one function will leave others quite intact; or will affect them, if at all, only much later. A state or course of intoxication, therefore, is always a progressive stimulation and narcotising of tissues, some being in one state, some in another. If we may speculate about the brain states that accompany the mental changes, we may say that a wave of stimulation and narcotising spreads over the tissues from one part to another, or more probably, acts selectively among co-ordinated groups of neurons, at first exciting, then depressing whatever it affects.

This simple statement, however, does not entirely explain the changes that occur in intoxication. The nervous system is an organism of balanced parts, one serving the purpose of holding another in check. When the higher func ${ }_{\top}$ tion becomes paralysed the lower which depends upon it for control is quite certainly released from control, and quite independently of stimulating effects of the drug upon it, may function excessively or respond to stimulus that 


\section{PSYCHOLOGY OF INTEMPERANCE}

in a normal condition would not arouse it at all. Increase of excitement in a part may also have the effect of drawing stimulus from and inhibiting other parts.*

There is a theory that the nervous functions are affected by alcohol in an order which is the reverse of their acquirement by the individual and by the race. The evidence from our own cases partly confirms this view, especially so far as it relates to large motor functions. Ribot ( $\left.{ }^{57}\right)$ states the view somewhat like this: At first there is an excitement in which reflection is diminished, a condition in which, apparently, the highest brain centers connected with thought are depressed or paralysed. Close attention, which is an effect of nice motor convergence, can no longer be maintained. Next the control of the tongue is lost; a man talks at random, and will tell all his secrets, showing that now all the higher inhibitions have disappeared. After this he becomes incapable of any continued plan of action. Then the will, under even its lowest and most impulsive form,

* Starke's conclusion is interesting in this conneetion. He maintains that alcohol has a specific effect in making the central nervous system anæmie and the skin plethoric, and in arousing the sympathetic nervous system. This is the physical aspeet of an effeet which on the mental side appears as a stimulation of our personal, intimate ego. The external world is dulled, and the internal world aroused, by a redistribution of energies in the nervous system, not by a paralysis of any function. 


\section{THE STATE OF INTOXICATION 129}

becomes powerless. Then the most delicate voluntary movements, those of speech and hand, cease to be properly co-ordinated. One degree lower, and he loses the semi-automatic movements, those of walking. Then muscular tonicity weakens. The man falls from his seat. Then reflex movements are abolished. Finally. there is a cessation of automatic movementsthose of respiration and of the heart. Ribot, of course, is describing a profound degree of alcohol poisoning.

Though our own experiments seem to indicate that in a general way this course of events takes place in intoxication, the suspicion remains that the process is not quite so schematic and simple as this description indicates. Some later acquired functions seem to be tenacious, and are not affected until there is a marked effect upon some apparently lower centres. And it seems that the effect of alcohol is selective among functions; as though, aside from the wave of paralysis which descends the levels of the nervous system, certain mechanisms were especially affected, and the effect upon these were the core, so to speak, of the intoxication.

This change that seems to be the core of the state of intoxication, however it is caused, is the change in the states of pleasure or displeasure-in the sense of well- or ill-being of the individual. Precisely what the physiological 


\section{PSYCHOLOGY OF INTEMPERANCE}

basis of this change is, is not clear. In fact, the physiology of pleasure and displeasure, and even the psychological nature of these states, is so much a matter of conjecture at the present time that perhaps it would be futile to discuss how they are affected by alcohol: whether alcohol arouses certain thoughts or attitudes of mind which in turn give pleasure, or whether something which may be called a mechanism of pleasure is directly stimulatedor whether the course of stimulation of brain centres is itself the basis of the change of feeling.* But it seems as though some definite mechanisms of the nervous system must be selectively influenced by the alcohol, and that thus, by mechanical means, the states of pleasure,

* Sajous calls attention to the fact that in the phenomena of alcoholism we have a manifestation similar to those produced by many poisons (the exaltation of mental faculties and increase in the sensation of well-being) and that these are like the effects of drugs that stimulate the adrenal system. ('The adrenal system, in Sajous' view, consists of the thyroid, the pituitary body, and the adrenals, connected through the sympathetic ganglia and the splanchnic nerves.) The adrenal secretion is the agency which, in the pulmonary air-cells, takes up the oxygen of the air, and which as a constituent of the hrmoglobin of the red corpuscles of the blood and of the plasma, carries this gas to all parts of the organism. Until we know more about such involved problems of secretion, and about the function of various products of the more obscure systems of the body, we shall not be able to give very definite and complete answers to physiological problems concerned in such intoxications as the alcoholic. 


\section{THE STATE OF INTOXICATION 131}

and finally of displeasure are artificially produced. Accompanying the first stages, or constituting them, are increased activity of the heart, increased flow of thought and feelings, a sense of ease of activity. But the widened range of emotion is the central change. Feeling increases and becomes dominant in the mental state; there is a sense of abundance of life, the mental horizon appears to be widened, and the intoxicated person enjoys a sense of expansion of the personality, which is none the less real to him because in most ways mental powers are not increased, but are actually diminished. The sense of personality is enlarged under the influence of an expansive feeling, and at the same time limitations based upon inhibitions of conduct and feeling are broken down. The more individual thoughts and adjustments are removed, and the more general or more social feelings and thoughts are increased. At the height of the stage of pleasure, the individual feels both his own personality, and his area of social contact widened. Memory is stimulated, and unused parts of the mind are brought into action. For a moment the individual has transcended his limited individuality, and has looked, as it seems to him, into a larger world. He has become a larger self, and life is richer in meaning. This, it seems, this moment of breaking down 


\section{PSYCHOLOGY OF INTEMPERANCE}

of the limitation of the individual, which each of the subjects of the experiment felt as a moment when all control might be thrown aside, is the state which is especially craved by the drunkard. Did such an outlook but really lead on to higher enthusiasms, and to those efforts and activities which $d o$ enlarge the outlook upon life, and give it richer meaning, we should be obliged to say that the function of alcohol is explained and justified. That these states did actually in the past stimulate thought and ideals; that alcohol once aroused social activities and enthusiasms and played a part in normal life can hardly be questioned. What the relation of such desires is to present ideals and experiences lies before us as the most important practical question of our study. The love of alcohol is essentially a love of life-a craving for a life more abundant. However inadequate and futile the means chosen to secure this larger meaning of life may be now, we may assert that a normal motive lies at the heart of it. How this normal motive may be satisfied; how the recreational life, the social life, and the work of the individual may be made to satisfy it, we can easily foresee, is the practical problem of the intoxication impulse, if the analysis up to this point has been correct. 


\section{CHAPTER VIII}

\section{A STUDY OF ABNORMAL CASES}

Nature has provided many opportunities for studying normal traits of the human mind in an enlarged or distorted form. In the abnormal mind normal cravings and activities which should have become controlled and organised are seen uncontrolled and distorted. Sometimes in the abnormal mind, one impulse comes to stand for and dominate the individual. It is enlarged, and out of relation and proportion to all the other impulses, and perverts the whole life. But such cases are not anomalies, produced by laws different from those according to which normal individuals are produced. They must be studied in relation to the normal at every point; and it is only by seeing the relation between the normal and the abnormal trait that the abnormal can be said to be understood at all.

A study of various classifications of drinkers discloses the fact that there are two general types of organisation which predispose to excessive drinking. (One is the undeveloped type of organism: intellectually and morally, per- 


\section{PSYCHOLOGY OF INTEMPERANCE}

haps physically, of a low order. Such are never able to transform lower enthusiasms into higher, and they always live on a low plane. They lack self-direction and purpose. They live in the midst of a civilisation which is too refined in type for them to imitate.

The second is the degenerate. People of this type commonly possess qualities which go with culture and high ideals, but they lack balance. To this class belong many people whose nervous systems are so constructed that they cannot control impulse, though usually ideals are normal, and clash with behaviour.*

Such broad generalisations, however, are far from satisfactory when applied to individual cases; and there is no more perplexing problem of individual psychology and physiology than the subtle differences which make it possible for one man to drink moderately throughout life, without danger of excess, while another, apparently as well constituted and living under as favourable conditions perishes in the presence of alcohol.

In order to secure reliable data about the alcohol habit sixty-five cases were studied at first hand. Most of these were men committed

* Williams (58) says that inebriates are recruited from two types, the hysterical and the psychasthenic. Wilson (59) has presented excellent clinical studies of types of inebriates, and emphasises the subtlety and complexity of the factors involved in the abnormal diathesis of alcoholism. 
for drunkenness and other minor offences in the Worcester County House of Correction. Some were cases confined in asylums for inebriatosin New York City. A few interesting accounts were obtained through other sources, among them some secured at the Jere McAuley Mission in New York. Each case was visited in person by the writer, and no fact has been included that was not obtained thus at first hand.

The main purpose of the study was to discover the nature of the craving for alcohol as felt by the drinker, the genesis of the habit in his consciousness, and the part it has played in his life. The result was a certainty that cravings which are naturally social in expression are at the bottom of all drinking of this class, that there is little personal initiative, and little or no specific craving for alcoholic drinks. Intoxication is a part of a social event, and has no other significance for the great majority of drinkers, even drunkards. What the man craves is social excitement, or something which, at his grade of intelligence, is best satisfied by social excitement. The man becomes and remains a drunkard because, in the class of society in which he lives, social life is almost invariably accompanied by drinking. It requires no very low order of moral standard for a man under these 


\section{PSYCHOLOGY OF INTEMPERANCE}

circumstances to become a hard drinker. All that is required is a nervous system rather more than usually susceptible to the effects of alcohol, and a low resistance to habit. Very few indeed are conscious of possessing a craving for alcoholic drinks, or of desiring a state of in-

v toxication except in its social form. Being actually drunk is an accident, and is usually neither intended nor expected. The drunkard usually deludes himself with the belief that the drunk from which he is just recovering is to be the last one, and that the next time he will

- drink only enough to be mildly excited, if indeed

- he will not abandon drinking altogether. These amiable decisions hold until he is the next time tempted by the presence of drinking companions. There are always men enough who are just taking a drink to keep up the suggestion for those who waver undecided whether to drink or not once more. We can go so far indeed as to say that intoxication is a social state, that a man is intoxicated in the proper sense of the term only in company, desires it only with reference to others in the same condition; that solitary, excessive drinking is a morbid habit, is sought usually for stupefaction, has well-marked features of disease, or eccentricity, and exists usually in those having other signs of mental deterioration of a pronounced kind. It is felt to be abnormal even 


\section{A STUDY OF ABNORMAL CASES 137}

by the hardest social drinker, who abhors solitary drinking as much as the temperate person abhors the ordinary drunkard.

In fifty-eight of the sixty-five cases studied there was no evidence of anything like a conscious craving for alcoholic drinks, although most of the men were confirmed drunkards. Nearly all had been committed more than once for drinking, and one was serving his sixteenth term for that offence. The statement usually made by these men was that, when alcoholic drinks had for any reason been cut off for from ten to twenty days, all craving for drink ceased. The testimony on this point, and the exceptions to the general rule, ean best be shown by quoting excerpts from the actual records of the cases. The language used is so far as possible that of the subject, taken down at the time of the interview, or immediately afterwards. What it lacks in elegance is perhaps compensated by directness and sincerity.

Case 1. Man, 25 years of age. Has been a drinker since fifteen. He has used a quart of whisky daily for years. Has drunk alone, but generally likes to drink in a crowd. He has no craving for liquor when he is in jail.

Case 2. Man, 31 years old. Drank his first glass at 24. Drinks socially altogether. He has been in the habit of being intoxicated every Saturday night. He has no craving for drink while in jail, nor during the week when he is out. When he is tired and thirsty a glass of beer tastes good; but after that, it is not the taste. He drinks for the feeling, or because he has lost control of himself, and doesn't care what he does. 


\section{PSYCHOLOGY OF INTEMPERANCE}

Afterwards he feels the disgrace of his actions keenly. He is strong, of athletic build, and in perfect health so far as he knows.

Case 3. Man, 36. He always drinks in company. He never intends to get drunk when he starts. Occasionally between drunks he will take a glass of beer. Trouble will always make him go and get drunk. When in jail he feels the loss of his pipe, but does not feel the loss of his drink. As a boy, he was very shy and bashful. As a young man he was in the habit of taking a few drinks before going to a party or social, in order to overcome his shyness.

Case 4. Man, 38. Has been drinking since he was sixteen. He very seldom drinks alone. Has no appetite at all for alcoholic drinks when he is in jail, and doesn't see why it cannot be the same when he is free. If he succeeds in going for two or three weeks without drinking he has no craving for liquor.

Case 5. Man, 52. He has been a drinker since he was sixteen. For the past few years has drunk very heavily. He drinks mostly in company. He drinks because he worries. Hasn't missed liquor since he has been in confinement. He feels the need of his tobacco. He has always been of a nervous temperament. He thinks he will never drink again.

Case 6. Man, 21. Has been drinking since he was fourteen. Has drunk alone a good deal. He likes to be alone when drinking. Has drunk as many as thirty glasses of liquor daily. He had been drinking heavily when he was arrested, but missed the liquor afterwards only for two or three days. It now takes more to make him drunk than when he began drinking.

Case 7. Man, 43. He has been drinking since twenty. If he takes one drink he is sure to take another. Doesn't like the taste, either of beer or liquors. It is for the feeling after it is down that he takes it. If there were no rum to be had, he would never have a craving for it.

Case 8. Man, 32. A very hard drinker. Doesn't care for the taste of liquor at all. Doesn't care anything about it until he gets into company. He never goes into a saloon alone. If he is worried about anything, he goes out looking 


\section{A STUDY OF ABNORMAL CASES 139}

for company and drinks. In jail he craves neither liquor nor tobacco, except chewing tobacco.

Case 9. Man, 43. Of melancholy temperament. His drinking is periodic. He always drinks alone. When he drinks with a crowd he spends too much money. He will go two or three months and have no desire for liquor at all. Once he went a year without tasting it. He feels certain that he will never drink again.

Case 10. Man, 50. He has been drinking since he was sixteen. He has never had a craving for drink. Never thinks of it when he is in jail. Does not like the taste of beer or whisky or any other kind of liquor. He never goes into a saloon to drink alone, even when he has plenty of money. He never goes into a saloon because he wants a drink.

Case 11. Man, 48. Has been drinking since nineteen. Doesn't like the taste of liquor. He never goes in to get a drink by himself. He drinks by sprees. When he meets two or three old friends he likes to go in and talk over old times, thus gets to drinking, and then can't stop. Misses tobacco much more than liquor. "A man doesn't need liquor; he does need tobacco." $\mathrm{He}$ is sure he is not going to drink any more.

Case 12. Man, 43. Has been drinking since he was twentyfive. Doesn't like the taste of liquor. Has no craving for it now, or ever. But he cannot take a glass or two and then stop. He always gets drunk when he drinks at all. His health is good, and he is not of a nervous temperament.

Case 13. Man, 40. Has been drinking since seventeen. At thirty he gave up drinking beer, and began to drink whisky altogether. He always drank alone, and every day. His usual allowance has been from fifteen to twenty glasses in a day. Four years ago he took a six weeks' treatment, and managed after that to go a year without drinking a drop. Has no craving for liquor at all while in confinement, but there is all the time a struggle against fatigue and depression. Always, if he has had nothing to drink for a month or two, there is no craving for it, and the return to drinking is accidental.

Case 14. Man, 18. Doesn't like the taste of liquor except 
after he has already been drinking heavily. For three or four weeks after coming to jail, he craved both liquor and tobacco. Now he does not think of either.

Case 15. Man, 36, A sailor. He drinks nothing when at sea. He misses it only the first two or three days out. Since he has been in jail he has missed his pipe, but he doesn't crave drink. He never drinks alone. Doesn't like the taste of liquor; it is the sensation that he cares for.

Case 16. Man, 35. The first drink was taken at fourteen. The only craving is on a hot day, when thirsty, and then he really feels a craving for a glass of beer. It is impossible for him to drink moderately now. When he drinks, he always drinks too much. When he hasn't had a drink, he doesn't want it. When he has, he wants more. He is in perfect health, so far as he knows.

Case 17. Man, 24. He doesn't like the taste of whisky nor crave it; but when he once has a taste of it, he can't stop short of extreme intoxication. $\mathrm{He}$ is never tempted to drink except when he is out with the boys.

Case 18. Man, 26. He has been drinking since twenty. After he has had one drink, he has a strong desire for more. Otherwise he has no taste for it whatever, and never thinks of it except when he is where there is excitement, and there is drinking going on. To have a good time is the beginning of his drinking.

Case 19. Man, 23. He has no craving for liquor. Once in a while he drinks alone, but never intentionally to get drunk. He likes the taste of whisky. When he is with a crowd he doesn't feel that he is having a good time unless he drinks. If he takes one drink, he always gets drunk.

In the seven cases which follow there is more positive evidence that the state of intoxication plays a part in the system of conscious desires of the individual. Those who think that the drunkard is a man who has a diseased appetite for drink, caused perhaps by the use of alco- 


\section{A STUDY OF ABNORMAL CASES 141}

hol, or who incline to the belief that a drunkard is what he is because he does not wish to "do right," will find in such cases material for reflection. They will see at least how intricately the drinking habit is bound up with all the most vital functions of a man's life. To control his habit, the man must sometimes change his whole life plan, create for himself new social interests, perhaps choose a new occupation, or withdraw himself altogether from his old social life. And then, when he has exerted all his will force, and taxed all his ingenuity, and has perhaps been many montlis or years without tasting an intoxicant, he may find that he is not yet secure against relapse. He may go through life never secure from attack, feeling as does our Case 22 that his drinking is a thing as external to his own control as is the most accidental calamity that can befall one, an event against which he has no resource for protection in his own will. And yet these indomitable habits are in the great majority of men not felt as a craving either for liquor or its effects, and the great mass of evidence $\checkmark$ shows that independently of the social life surrounding the individual, they have little contròl over him.

Case 20. Man, 49. Unmarried. There is no nervous disease nor insanity in the family so far as he knows. His father died at seventy-six years of old age; his mother at fifty 


\section{PSYCHOLOGY OF INTEMPERANCE}

of pneumonia. He has six brothers and sisters none of whom use liquors. He himself has always been healthy. The first drink was taken at sixteen. He used to set up tenpins in a bowling alley, and began to drink beer there. He had left school at fourteen and had always been a good boy. For a long time he drank beer regularly, but never tasted liquors. At last he began to use stronger drinks. He never liked the taste of them, but used them for the feeling, usually beginning to drink when he was discouraged. He has never had the habit of daily drinking, but has drunk by sprees. Between drunks he would not drink at all. He has tried very hard to overcome the habit. He knew it was wrong, and knew that it was hurting him in every way. He would fight his inclinations for several days, but sooner or later would get in with the boys. Of late years he has drunk mostly alone. He went without drink once for two years, from the age of about twenty-seven to twenty-nine. At that time he was working for good pay, and made up his mind to stop drinking, and succeeded.

Every week for the last seven years he has spent two days in drinking and three days in recovering from the effects of it. In this he has been perfectly regular. Although, during all these years, he has never once missed his spree, he thinks that if there had been no way of obtaining liquor, he would not have craved it. He has no craving for it now at all, and doesn't even think of it, when in confinement. But when he was working, every Saturday he would think of it all the afternoon, would go home in the evening, change his clothes, and go down town. He would walk about for a time, until about eight o'clock. Then he would go in and get a glass of beer. That would be the beginning of his drinking, which would be kept up steadily until Tuesday. He knows of no cause for his drinking, and cannot in any way explain the impulse which is quite beyond his control. He never left the shop Saturday afternoon without intending to stay sober, and to control his desire. And each time when he was sober, he determined never to drink again. He feels that there is some peculiar weakness in his nature, and thinks that even in the absence of liquor, he would have found some 


\section{A STUDY OF ABNORMAL CASES 143}

other way to ruin himself. He says that now he feels quite convinced that he will never drink again. In temperament, he is nervous. As a child he was restless and uneasy, of vivid imagination, honest and truthful, and quick-tempered. $\mathrm{He}$ has never eared much for the society of the other sex.

Case 21. Man, 38. An only child. This man is a periodical drinker. At eleven he was made drunk by companions, and was taken home by two men. He doesn't remember feeling sorry. As a child and growing boy he was very nervous and high-strung. At seventeen he began to drink regularly and has been a periodic drinker from that time. At thirty-two he broke his leg, and at that time began to use opium to kill the pain. He has used it ever since. Morphine makes him feel dull; but it is quite different with alcohol. A little of any alcoholic drink makes him thrill all over. The least taste of any liquor will set him going, even sweet eider, unless it is just out of the press. Morphine he now uses only after he has been drinking heavily. It sobers him, and makes him fall asleep, and so puts an end to his spree.

His periods are usually precipitated by meeting a friend. Meeting an old comrade affects him in a strange manner which he cannot explain. He is inclined to be very intense both in his likes and dislikes, and it is the strange feeling aroused by meeting an old acquaintance that is more likely than anything else to lead to a long spree. He dislikes the taste of liquors of all kinds, even detests them. His periods come now at intervals of from three months to a year. Once he went two years without drinking. Many times he can control the impulse even when it is strong, but he is very easily and strangely influenced. He feels that he will control his appetite altogether sometime, but expects another attack when he is released this time. He thinks he is safest when he is where liquor can readily be obtained. For when he is away where he cannot get it, there is likely to be an increasing craving. Perieds are most likely to come on when he is discouraged or depressed. He is by nature of an unstable disposition, loves frequent change, and has worked at many trades. As a boy he had plenty of money, had a good edu- 


\section{PSYCHOLOGY OF INTEMPERANCE}

cation, and did not expect to earn his own living. He feels keenly the disgrace of his condition.

Case 22. Man, 34. An actor. He is in good health, and has no nervous disorder. His first drink was taken at twelve. He was out skating, on a cold night, and drank cherry brandy. His next drink was taken when he was seventeen. He was working in a bank, came down town too late for breakfast, and ordered a glass of beer. He was alone. After this, he drank more or less, always socially. He was occasionally inwoxicated but only at times of unusual festivity, such as New Year's Day and the like. He was married at twentyone. From twenty-one to twenty-seven he drank more or less steadily but only in a social way. At twenty-seven he was separated from his wife. After that he drank to excess in order to forget his troubles. He drank alone altogether, and continuously. He rented a room, and began a spree which lasted for six months, for during that time there was not a day in which he was fully sober. Since then his drinking has been somewhat periodical. He went West to work on a ranch, and for eight months drank no liquor of any kind. He was where it could not be obtained conveniently, and he had no craving for it. He was offered liquor a few times during that period, but refused it. Lately his sprees have been becoming more frequent. Sometimes he can go for a few weeks and drink more or less moderately, but he invariably ends in an uncontrollable spree. Five years ago he spent four weeks at the Keeley Cure, and after that went three years without drinking. His sprees always last as long as he has money or can get whisky. As regards the craving, when he hasn't been drinking he doesn't crave liquor, but when he has once started the need is imperative. He has had no craving since he came to the inebriates' home, although he has not been under restraint. He thinks that if he lived all the time in such an environment he would never think of liquor. The craving is more of a mental than a physical craving. It is a desire to get away from himself. The craving for drink is a craving which any other pleasure equal in degree would satisfy. It is a disgust with present conditions, and a desire to cut loose from old ruts and have 


\section{A STUDY OF ABNORMAL CASES 145}

a change. Of late his sprees have always been preceded by a fit of despondency. Looking back, he can trace two different conditions which have been likely to bring on a period of drinking: one is unusual depression; the other, unusual success. The nature of his spree differs greatly according as one or the other of these motives initiates it. If he starts in a happy mood he is jovial all the time; if he starts drinking when he is depressed, he is unsocial and silent, and there is no stage of exhilaration. He does not feel at all sure that he will be cured by his present treatment. One might as well ask him whether he intended ever to have pneumonia again. It is a thing which he does not control.

Case 23. Man, 45. He was seventeen when he took his first drink. It was at a wedding. After that he drank steadily, though his drinking tended to be somewhat periodical from the start. His sprees occur at intervals of from three to six months. The longest period of abstinence was a year and a half when he was thirty-eight. During all that time he never had any craving for liquor whatever. Excitement and the renewal of associations broke the spell. His sprees are induced usually by associating with people who drink, or by misfortune, or anger. He does not like the taste of alcohol, nor crave drink in any way; but if he begins drinking, he cannot stop. He has been arrested eight or ten times, each time for drinking. When drunk he is peaceable and jolly. He never drinks alone. Probably never drank twenty-five drinks alone in his life. He craves tobacco, incessantly, and the want of it when he is in confinement makes him nervous and irritable. He doesn't feel at all certain that his drinking is permanently stopped. He thinks confinement has no beneficial effect, for a man cannot be cured of drunkenness by loneliness. The only way to cure him is to keep him away from drinking society.

Case 24. Man 48. Born in Ireland. For the last twentyeight years, he has been drunk about once a week. When he is out of jail, he has a craving for drink. It is like a gnawing in the stomach, as though he wanted something to eat. He thinks about it all the time until he gets a drink. When he is in jail, he doesn't think of it at all. Tobacco 


\section{PSYCHOLOGY OF INTEMPERANCE}

he constantly craves and it would be the same with whisky probably if there were any chance of getting it in his present situation. It is the thought of it which puts the appetite down into the stomach. He has taken the pledge a good many times, and kept it once for a year and a half, fifteen years ago.

Case 25. Man, 40. Is nervous, weak, and emaciated. Suffers from insomnia. Says he doesn't know of any worse drunkard than himself. He left school at the age of fifteen, and at eighteen, when out with a crowd of boys, drank beer for the first time-two glasses. He has never been able from the very start to drink moderately. Still he thinks he has no craving for liquor except when he has already been drinking. $\mathrm{He}$ never cares for it when alone, except after drinking, and then he would walk miles to get it. He managed once to stop for a few months, but soon got out with the boys again. He thought at the time he would be able to drink moderately but he was soon as bad as ever. His sprees usually last until he gets out of money, and sometimes he drinks almost continuously for two weeks. He never thinks of liquor when he is in jail, but craves tobacco. He thinks he has been growing worse lately. The excitement and exhilaration after drinking is less, he seems to lose his mind, and can remember afterwards but little that has happened. He has frequently signed pledges and once or twice has gone three or four months without drinking. He means to do right, and has sworn time and time again never to touch liquor again. The craving for liquor, as he feels it, is hard to describe. He recognises it as a feeling of craving and worrying, and it is entirely different from the craving a man has after he has been drinking. Since he has been in jail he has felt worried and depressed, but he has felt nothing which he can call a desire for liquor. Sometimes his desire can be controlled. Once when he had not been drinking for two months he came to the city on a holiday, and going by a saloon it seemed as though he must go in and get a drink. The thought almost made him dizzy; he thought he could take no interest in anything, and felt as though all the fun would be dull and monotonous, unless he should have a drink to help him enjoy 


\section{A STUDY OF ABNORMAL CASES 147}

it. But he resisted the temptation, went into a restaurant and had dinner, and all the rest of the day had no thought of drink. Sometimes, when he has a craving for drink, other things will satisfy him, as non-alcoholic beverages, or a dinner, as in the case spoken of. The presence or odour of alcohol will not always arouse a craving for it. He would often be where there was liquor in plenty, and would have no desire for it, and couldn't be induced to touch it.

Case 26. Woman, 52. In appearance she is strong, wellnourished, apparently of strong will, and very intelligent. She is a very religious woman, and is very sensitive about her degradation and her menial position. At times she is unsocial, irritable, and sarcastic. She has been a periodic drinker for the past seventeen years. The periods have usually come at intervals of from four to six weeks. Once she went six months without drinking. Thinks she has been worse since the age of about forty-four. For the past four and a half years she has been abstinent, having been in voluntary confinement in an asylum for inebriates. She is not in any way under restraint. She goes out on errands, and to ehurch, and during the day works, serving the institution in the capacity of cook. She still has the craving for alcoholic drinks, and it is likely to come on about once in a month. At these times she goes to the matron and asks to be watched. She thinks that she will have to fight this craving all her life. Her only physical ailment, so far as she knows, is a slight dyspepsia, accompanied by nervousness. If anything goes wrong her craving is likely to be made more intense. At these times she feels as though she must constantly restrain herself to keep from going out to get a drink. At communion service the taste of unfermented wine makes her "mad" to drink the whole cup. The craving is not a thirst, and is very different from the craving she used to have after drinking. . Then the craving would be irresistible. She would walk from Harlem to the Battery to get a drink if necessary. Her craving as far as she can analyse it, appears to be a longing made up of depression, accompanied by increased sensitiveness to slights of all kinds, and a general nervous irritability. 


\section{PSYCHOLOGY OF INTEMPERANCE}

These facts for the most part tell their own story, and little needs to be added by way of comment. It is certain that the craving for alcohol, in the sense of a physical craving, has little to do with the appetite of the drunkard; and, in general, there is little to indicate that there is any kind of a specific craving for drink. (The craving for alcohol, whatever it may be, is more than a desire to take a drink. It is a craving for something which accompanies the drink.) With one or two exceptions the testimony is universal that after a man has been without liquor for a few days (ten days is the time most frequently mentioned) there is no longer a longing for it. This is especially true when a man is situated so that it cannot be obtained. The Irishman of Case 24 expressed it well when he said that it was the thought of the liquor that puts the appetite down into the stomach. This testimony is emphatic, and must be accepted as correct within the limits of the introspective power of these subjects. The testimony is 1 quite as strong that for the first few days in confinement the craving for alcohol may be intense and persistent, and with it then may be physiological disturbances, such as a general distress, burning in the throat and stomach, weakness and trembling. Such testimony confirms the conclusion of Starke that alcohol has little or no power to create, in the body, a crav- 


\section{A STUDY OF ABNORMAL CASES 149}

ing for itself, such as is popularly supposed. The usual reply (which came to be expected because of its frequency), when a man was asked whether he felt the loss of his liquor in confinement was, "I never think of it," or, "It never bothers me at all." On the other hand the testimony is equally strong that tobacco is greatly missed by the man who is accustomed to it and cannot get it. The change of expression of the face when tobacco was mentioned left no doubt, in a great many cases, of the difference of attitude toward it and toward alcoholic drinks. Tobacco was certainly craved by these men, in some cases with almost pathetic intensity. Many said, "I think of it every day.",

There are several reasons for the difference in the feelings toward alcohol and toward tobacco. One is, that tobacco is sometimes to be had in jail, and can be used secretly; occasionally its use is permitted by the authorities, provided it is not used openly. So there is always a possibility of obtaining tobacco, especially chewing tobacco. But smoking is not allowed, and yet there is in many cases a craving for it. Another reason is that tobacco is not connected with the disgrace and inconvenience of imprisonment, and therefore the desire for it is not inhibited. There is still another reason, the centre of the whole matter, it is likely, and the explanation of the nature of the 


\section{PSYCHOLOGY OF INTEMPERANCE}

craving for drink. Tobacco is used, perhaps most enjoyably, when a man is quiet and alone. It is used for its soothing effects. It is a solitary habit, and not essentially a social habit; and the solitariness of prison life continually suggests the use of this accustomed companion of quiet moods. The alcohol habit, on the other hand, is decidedly not a solitary habit, but through and through a social habit. The conditions of prison life are unfavourable for keeping alive the craving for alcohol, for they entirely inhibit the social mood in which alcohol is most normally used. It is certain at least that whatever craving for alcohol these men had, it was not recognised by them as a longing for alcoholic drinks. The sudden disappearance of it from consciousness, after a few days, leads to the same conclusion. The longing for the alcoholic stimulation is but a part, and in many cases a small and unessential and subsequent part of a larger impulse, a longing for social exhilaration and elevation of the feelings, for a change in the attitude toward life, realised nine times out of ten through social relations.

The only conscious craving for alcohol as such is to be found in the neurotic cases.* The

"I have not tried, in presenting these cases, to distinguish clearly between ordinary drunkenness and true dipsomania which is a comparatively infrequent condition. Dipsomania is now recognised to be a mental disorder, the main symptom of which is an uncontrollable periodic desire for a critical 


\section{A STUDY OF ABNORMAL CASES 151}

clearest example is Case 26. In this case there is certainly a periodic nervous disturbance of some kind, which is interpreted as a craving for alcoholic drinks. But on analysis the sharpness and definiteness of the specific craving seems to fade away. It is a nervousness, a depression, a general irritability of the mind. The strongly fixed belief that there is indelibly stamped in her mind a longing for alcohol helps to keep up this desire and to concentrate it. Her nervous system has become accustomed to find relief for a neurotic condition in the stimulating and stupefying effects of alcohol, but perhaps under other experiences it might have become habituated to other modes of unnatural satisfaction, or to relief in normal activities, which would have constituted a cure of the nervous disorder.

In other cases the unfortunate effect of the popular belief in the organic and specific nature of the craving for alcohol, which is so per-

mental change, which is most readily secured by drinking alcohol. On the practical side dipsomania is of chief concern to the medical specialist. To psychology it suggests many interesting problems. Fspecially its rhythms need to be interpreted with reference to the mental and physical rhythms that have been established in the race. The next step, perhaps, in the study of this mental disorder is the application of such methods of analysis as have been developed by the psychoanalysts. Such studies could hardly fail to discover deep roots in the emotional life, and would no doubt throw light upon the whole problem of inebriety. 
sistently enforced upon the mind of the drunkard by people who are trying to help him, is to be seen, making him lose hope, and in some cases, it is likely, taking away the possibility of ¿cure.

Further evidence that the longing for alcohol is a complex mental attitude, and not a specific craving, is to be found in the manner in which many inebriates have been cured. Cures by religious and moral conversion are of course mental in nature. They cure the craving for drink by strongly changing the life interests, and bringing the man into a new social environment, away from drinking companions: that is, by substituting a normal incitement to a state of pleasurable and intense consciousness for an abnormal one. Leuba $\left({ }^{60}\right)$ gives in detail several cases in which the craving for drink was removed instantly by conversion. From his monograph the following are quoted:

Man, 42. Converted when thirty-three. Sometimes drunk for a week together. Then not a drop for a whole month. Never went more than a month but once, when he joined the Good Templars, when he went without drink for three months. He experienced sudden conversion.

"From that hour," he says, "drink had no terrors for me. I never touch it, never want it."

Another says:

"I believe that God took away the appetite for drink that night when I asked him."

A man, 44. Converted in 1883. Had been a hard drinker. Made many resolutions, but could not keep them. Had a 


\section{A S'TUDY OF ABNORMAL CASES 153}

sudden sense of powerlessness, experienced conversion. Conversion took place on Sunday.

"On Monday," he says, "there was no desire for drink. Since that day I have not had to surmount strong temptations."

Two of my own cases show well the method of the mental cures of temperance, and indicate the nature of the craving.

Case 27. Man, 48. The first drink was taken at eighteen, with a crowd. The drinking habit became settled at twentyeight. Began with beer, but at about the time mentioned changed to heavier drinks. He would go months drinking everything, and then stop for a week from physical incapacity to drink any more. He drank to keep up an exhilaration, so that he could do more work. Drank when he hated the taste of liquor and could hardly get it down. But he had to take it in order to appear right. Took more and more as time went on. Before he was thirty-eight he had tried several times to reform. He changed his residence, but it did no good. He always drank alone, for he wished no one to know about it. He never stayed in a saloon longer than was necessary to get what he came for. When he was forty-four, and after a season of hard drinking, his wife made him promise to reform, and urged him to become converted. He had always scoffed at the idea that a change of heart would do any good, but he went to a clergyman and told him he would sign a pledge for a year. The clergyman would not accept such a pledge, so he made out a life pledge, and signed that. $\mathrm{He}$ gave his wife all the money he had on hand, except a very little, thinking that if he was not cured he would buy some liquor. For a few days after signing the pledge, he was terribly weak, and unable to act. All the time there was a craving for liquor. He knew that it would put new life into him and make him act. This craving was cured in one day, thus: It suddenly occurred to him that he was not more than half honest in the matter, so he went to his wife and gave her the rest of his money and confessed his intentions. 


\section{PSYCHOLOGY OF INTEMPERANCE}

As soon as he had done that it seemed as if the craving had entirely disappeared, and from that moment, for nearly three years, he had no more craving for alcohol. His health was good, he worked at the hardest kind of work, chopping in the woods, and so far as he knows, felt no effects of his hard drinking after the first two weeks. At the end of three years, when on a visit at a summer resort, he drank two glasses of cider. The next day he was as weak as ever. He found out that his trouble had not healed; he became frightened, fearing that his drink habit would return then and there, and started away in the rain to walk seven miles to the station, intending to go home. When he reached the first house he stopped and asked for a drink, and got it. A little further he stopped again, and had more. Thus commenced a downfall more complete than the first. He has continued drinking up to the present time. It is now necessary for him to have alcohol to make him think. If he goes a day without it, his nerves seem to be shattered. He could not add a column of figures unless he had his drink in the morning. Has a craving for liquor which he cannot now resist.

To test these statements he agreed to submit to experiment. He was tested on several days as to ability to add columns of figures and in other simple mental operations. On four consecutive days, on which by agreement, he took no alcohol, he did each day better than the day before, and on the whole much better than on days on which he took alcohol. During the abstinent days he felt no craving for liquor, because he knew he was to have none.

Case 28. Man 49. Had finished college at eighteen and went to work in a bank. At twenty-two he began to drink steadily, using mostly brandy and port winc. He drank for the taste of the liquor. Was a member of clubs and drank at socials. He soon began to use liquors to excess, and 


\section{A STUDY OF ABNORMAL CASES 155}

drank both for the taste and the feeling. It was steady drinking all the time, and altogether in company. Later he drank alone, but never to get drunk alone. There was hardly a day that he didn't drink excessively, though he never went so far as extreme intoxication. The last two years of his drinking (from 42 to 44 ) he made little effort to control his appetite. He kept up his business, and did better work after he had had two or three drinks. He was doing also literary and lecture work at the time, and always drank heavily before going to make a speech.

He stopped drinking at the age of forty-four. Had been to a social at a club, and had drunk heavily all night. In the morning as he was walking with three or four companions, it suddenly came to his mind that he was leading a useless life, and he told the men he was with that he wasn't going to drink any more. They laughed at him, and told him he couldn't stop. Drunk as he was, he sat down and made out an agreement not to drink any more from that day (April 14) to July 4. This he agreed to sign if one of the others would. One agreed, so he signed the paper and gave it to his friend. With the remark that so long as he had the agreement he thought he wouldn't sign it himself, the companion put it into his pocket without signing it. This angered him and he determined to keep the agreement whether the other man did or not. He drank no more that day, and left the men and went home, feeling sick. He went to a doctor and told him what he had done. The doctor told him he must leave off by degrees or it would kill him. But he refused to drink. After a week there was no craving, and he refused liquor ten times a day at least, for the next six months. He has never drunk since, now four years. Very frequently now he goes into a saloon with friends, but always calls for nonalcoholic drinks. The odor and sight of liquor arouse in him no craving whatever. He has noticed that since he stopped drinking he cares less for the society of men, and feels that in a way his social feeling is weakened.

In other forms of cure of inebriety the principle is psychic. Most of the inebriates' homes 


\section{PSYCHOLOGY OF INTEMPERANCE}

depend upon moral influence and social environment. The principle of such a cure as the Keeley Cure seems largely, if not altogether, psychic. In the methods used by regular practitioners reliance is placed upon moral influence, and general toning of the nervous system. Some methods make use of physical means. Some merely substitute drugs which have an effect similar to alcohol. In some cases emetics are given with alcohol in such a way as to create a strong association between the taste of alcohol, and the memory of the nausea. But such cures are makeshifts and do not reach the bottom of the trouble.

Evidence from our cases and other data show that the craving for alcohol or intoxication, and the type of social interest which accompanies it, or of which it is a part, is not a craving of early youth. It does not as a rule show itself in school days. But when a boy goes to college, or when he leaves school and comes under the influence of older men, the drink habit is likely to be commenced. In some cases in which the first drink was taken early, perhaps at nine or ten, the real history of the case does not begin until long afterward. In almost every case the beginning of drinking was social. In but two instances was the first drink taken alone. Below is printed a table showing the age at 


\section{A STUDY OF ABNORMAL CASES 157}

which the first glass was taken in sixty-five cases.

\begin{tabular}{c|c|c|c|c|c}
\hline \hline Age. & $\begin{array}{c}\text { Number } \\
\text { of cases. }\end{array}$ & Age. & $\begin{array}{c}\text { Number } \\
\text { of cases. }\end{array}$ & Age. & $\begin{array}{c}\text { Number } \\
\text { of cases. }\end{array}$ \\
\cline { 5 - 6 } \cline { 5 - 6 } & 1 & 20 & 6 & 31 & 0 \\
\cline { 5 - 6 } 10 & 1 & 21 & 1 & 32 & 0 \\
11 & 1 & 22 & 5 & 33 & 0 \\
12 & 2 & 23 & 0 & 34 & 1 \\
13 & 0 & 24 & 1 & 35 & 1 \\
14 & 5 & 25 & 3 & 36 & 0 \\
15 & 6 & 26 & 2 & 37 & 0 \\
16 & 10 & 27 & 2 & 38 & 0 \\
17 & 8 & 28 & 0 & 39 & 1 \\
18 & 5 & 29 & 0 & 40 & 1 \\
19 & 1 & 30 & 1 & & \\
\hline
\end{tabular}
cases.

Table showing when the first drink was taken in sixty-five

Below are tabulated 498 cases of inebriety with reference to the time when the drinking habit was formed. This does not refer to the time when the first drink was taken, but when more or less regular drinking began.

By referring to the tables one will see that among the sixty-five cases more took the first drink at the age of sixteen than at any other time, and from the larger table the fact is obtained that at twenty the habit of drink is most often established; and that there is a second danger period in the early thirties. Parrish $\left({ }^{61}\right)$ says that the drink habit does not declare itself until the demands upon the nervous system come to be exorbitant, and that its terminal 


\section{PSYCHOLOGY. OF INTEMPERANCE}

\begin{tabular}{|c|c|c|c|c|c|}
\hline \multirow[t]{2}{*}{ Age. } & \multicolumn{2}{|c|}{ Number of Cases. } & \multirow[t]{2}{*}{ Age. } & \multicolumn{2}{|c|}{ Number of Cases. } \\
\hline & Males. & Females. & & Males. & Females. \\
\hline $\begin{array}{l}10 \\
11 \\
12 \\
13 \\
14 \\
15 \\
16 \\
17 \\
18 \\
19 \\
20 \\
21 \\
22 \\
23 \\
24 \\
25 \\
26 \\
27 \\
28 \\
29 \\
30 \\
31 \\
32\end{array}$ & $\begin{array}{r}2 \\
0 \\
4 \\
6 \\
8 \\
26 \\
14 \\
19 \\
35 \\
18 \\
50 \\
29 \\
32 \\
21 \\
22 \\
17 \\
14 \\
16 \\
13 \\
8 \\
20 \\
4 \\
3\end{array}$ & $\begin{array}{l}0 \\
0 \\
0 \\
0 \\
0 \\
0 \\
2 \\
0 \\
1 \\
2 \\
3 \\
0 \\
0 \\
2 \\
1 \\
0 \\
4 \\
3 \\
2 \\
3 \\
1 \\
5 \\
0 \\
1\end{array}$ & $\begin{array}{l}33 \\
34 \\
35 \\
36 \\
37 \\
38 \\
39 \\
40 \\
41 \\
42 \\
43 \\
44 \\
45 \\
46 \\
47 \\
48 \\
49 \\
50 \\
51 \\
52 \\
53 \\
54\end{array}$ & $\begin{array}{r}\mathbf{1 0} \\
\mathbf{8} \\
\mathbf{9} \\
\mathbf{3} \\
\mathbf{2} \\
\mathbf{2} \\
\mathbf{1} \\
\mathbf{3} \\
\mathbf{1} \\
\mathbf{2} \\
\mathbf{1} \\
\mathbf{2} \\
\mathbf{2} \\
\mathbf{1} \\
\mathbf{1} \\
\mathbf{2} \\
\mathbf{5} \\
\mathbf{3} \\
\mathbf{1} \\
\mathbf{1} \\
\mathbf{0} \\
\mathbf{2}\end{array}$ & $\begin{array}{l}5 \\
4 \\
2 \\
2 \\
2 \\
0 \\
4 \\
0 \\
0 \\
1 \\
1 \\
2 \\
0 \\
1 \\
0 \\
0 \\
1 \\
0 \\
0 \\
0 \\
0 \\
0\end{array}$ \\
\hline
\end{tabular}

Table showing the age at which drinking was established in 498 cases $(62)$.

period comes with as much certainty as does its initial stage. He thinks that there is an inebriate climacteric in every life when nervous periodicities become faint, when internal and external excitants to intoxication lose much of their vigour, and the inebriate diathesis is too feeble to respond to excitation. Between forty and fifty a great number of spontaneous recoveries occur, and about twenty-five years closes the drinking period, either by exhaustion of the desire or by death.

Our Case 28 is an illustration of this exhaustion or sudden cessation of the drink im- 


\section{A STUDY OF ABNORMAL CASES 159}

pulse from apparently inadequate cause. In this case the subject testifies to a weakening of the social sense. Crothers ( ${ }^{63}$ ) says that there are periods, from seventeen to twentyfive, and from thirty to forty, in which the liability to contract the drink habit is greatest; and that it is most likely to die out between forty-five and fifty, or from fifty-eight to sixtytwo. What the significance of the second period in each case may be is not clear. The period from seventeen to twenty-five is the adolescent stage when craving for an abundant life is strongest, and is most likely to become perverted or diseased. The intoxication impulses that are a part of the temperament of adolescence are then most powerful, and are most capable of direction into normal channels. The period from forty-five to fifty is the period of the decline of these impulses because it is a time of lessening, both in man and woman, of the temperament based upon the procreative life. Sexual impulse need not disappear, but the dynamic power of this instinct wanes; it no longer creates force to drive the enthusiasms; and the individual must depend upon habits formed earlier in life to carry on his enterprises. He enters upon a period of perfected self-control, and habits of drinking and other habits become manageable to a greater extent than before. Conversion of drunkards, ac- 
cording to Superintendent Hadley of the McAuley Mission in New York City, is less likely to be accomplished after fifty. If habit is not checked with the normal waning of the social and sexual life it is likely to run on to the end of life, and to be morbid in character, to a greater extent than perhaps a much more violent and persistent intoxication impulse which culminates and closes earlier. Dr. Braintwaite, $\left({ }^{64}\right)$ Superintendent of the Dalrymple Home in England, says that most of the cures are accomplished by forty-five, though certainly many cases do well under treatment even as late as fifty-five or sixty. The younger cases are most unsatisfactory. "Very few indeed," he says, "succeed in getting right under twentyfive or twenty-six." If the physiological basis of the drink impulse is an "alcoholised protoplasm," as some think, it is difficult to account for such facts. The opposite would be expected. The body but slightly habituated to the effect of alcohol would throw off the craving for it more easily than one which has been subjected to a course of poisoning for many years; and would feel less the craving for it afterwards, and would be in less danger of returning to the habit. But such is not the case.

These facts show conclusively, at least for the range of cases studied, that drinking is strongest as a habit during the most active 


\section{A STUDY OF ABNORMAL CASES 161}

decades of a man's life. It is not a steadily increasing habit perpetuated by the effect upon the body of the assaults of alcohol, but it is mentally determined and runs parallel to, or is at least conditioned by, the great movements of energy of the organism, which underlie all the enthusiasms and interests of life. It runs through the active years and then tends to decline.

This is not equally true, however, of all the motives for drinking, and it is possible that the later periods mentioned by Crothers correspond to periods in the development of what we have called the narcotic motives for drinking. When life begins to lose its charm, and the "shades of the prison-house" close in, and the first realisation comes that the future is to be an outcome of the past, which is likely to happen in the early thirties, the motive for narcosis comes in. There is evidence that in both sexes the time of the early thirties is critical. It is the age at which many breakdowns occur, when other habits besides the use of intoxicants may for the first time appear. Whether the second period of greatest chance of recovery mentioned by Crothers $\left({ }^{65}\right.$ ) (from fifty-eight to sixty-two), is the time when these narcotic motives are likely to cease is not clear, whether with the senescent blunting of the emotions the acuteness of pain is diminished, and 
there is no longer the craving to turn the edge of distress by artificial means.

All such facts of course have an important bearing upon the theory of the intoxication impulse, and upon the practical problem of the control and cure of drinking and inebriety, both in individual cases and in its social aspects. When we legislate against the use of alcohol we should do so with the knowledge that we are enacting laws against an impulse which is a part of the virile and normal periods of man's life, that it is a vice in many ways based upon power and virtue. We are combating a strong force in human life; and it may turn out that direct opposition is the least effective of the methods of controlling it. Such conclusions or forecasts are strengthened by recalling the fact that alcoholic intoxication has been in the past expressive of periods of racial growth. The abnormal and immoral expressions of this growth force, though none the less to be condemned and fought against because of their origin and their relation to normal growth, must be stemmed by methods that take into account in their modus operandi the nature of the impulses upon which they are based. How strong the intoxication impulse may be, how firmly rooted in the social life of a man, how closely related to all his interests, how persistently suggested by all his associations in 


\section{A STUDY OF ABNORMAL CASES 163}

life, has been shown, it is hoped, by the review of cases and the interpretations of them made in this chapter. But before undertaking to look into the practical questions which spring up on all sides from such a study of intoxication motives, it will be well to see what theories about the nature of drinking have been propounded from time to time; and in general how the facts have been interpreted. 


\section{CHAPTER IX}

THE THEORIES OF THE INTOXICATION IMPULSE

Ir would be surprising if an impulse so deepseated in man as the intoxication impulse, so profoundly connected with so many of his activities and with his deepest pleasures and pains, had not aroused much thought and theory, popular belief and scientific enquiry. There is, indeed, a vast amount of published. opinion about alcohol and its use, some thoughtful and temperate, some fanatical and absurd; but all interesting. It would be quite impossible to put into a chapter a review of all that has been said, but some main types of opinion and theory may be mentioned-enough to show the range of points of view, and especially to indicate the practical attitudes that have been derived from them.

A prevailing opinion about the use of alcohol, one which makes up the philosophy of many temperance workers, is that intoxication and indeed all desire for alcoholic drinks, is a sin, and that it requires no explanation. Man has fallen from a state of primitive virtue and has wilfully accepted or sought habits that he 164 


\section{THEORIES OF THE IMPULSE 165}

knows by an infallible inner conscience to be wrong, and displeasing to God; or wrong because displeasing to God. This view asserts that the drunkard is what he is because he is not willing to be anything else; or because he is not willing to seek the strength from Above which would take away his sin. In an extreme form this view declares that every man's conscience tells him that any drinking of alcoholic drinks is sinful, and is desired because it is a sin.

In the popular mind, too, representing the other side of the argument, is the opinion that moderate drinking at least is not a sin but is allowable, satisfying a natural thirst or craving, akin to a normal appetite for food, or for any drink. Varying with locality and class of society is the opinion that a slight "elevation," or an occcasional excess, is also morally allowable, and dictated by a man's natural desire for pleasure. Whether anyone morally justifies habitual excess, or finds in it an expression of a normal motive, is doubtful. Aside from social ideals there seems to be an inner feeling which disapproves of excessive drinking, and if it does not regard it as sin it at least condemns it as abnormal, because it conflicts with purposes now recognised as the highest. However hard a drinker a man may be, he reserves a contempt for the one more given 
to excess than himself, the habitual, solitary drinker, who drinks to intoxication or stupefaction, being at the bottom of this social scale.

Coming now to the theories of literary and scientific writers, there are many points of view, and many conflicting opinions. Nordau $\left({ }^{66}\right)$ says that the craving for alcohol is a longing for relief from pain and an expression of a need for stimulation, there being a general condition of neurasthenia, especially noticeable in the upper classes of society, and due to the fatigue caused by the sudden incoming of machinery, rapid transit, and exciting occupations. We have seen that this is certainly not an adequate explanation of the intoxication impulses; Nordau has singled out one, the less important, of two motives.

Lett ( ${ }^{67}$ ) asks, "Why do men drink?" and gives much the same answer as Nordau, "Because there is pain. The healthy man has no pain and needs no stimulant. One kind of pain, unrest, is the outcome of an unstable nervous organism. Disquietude, unrest, pain, are the causes of drinking."

A very different view comes from a recent writer, Starke, $\left({ }^{68}\right)$ who sees in the use of alcohol a normal appetite, and a normal craving for a certain mental effect. In the first place, in Starke's opinion, alcohol is a food; it is burned in the body and produces heat, and can there- 


\section{THEORIES OF THE IMPULSE 167}

fore be used in place of other food, its action being like that of the carbohydrates. But alcohol also has an effect which can be called a stimulation of the ego. It arouses temperament, sentiment, talents, and intellectual appetites. It excites the personal, intimate self and brings out in a man that which he essentially is. With this mental effect goes a physiological effect which is also hygienic, and increasingly so as society becomes more strenuous in its demands upon the powers of the central nervous system. It diminishes the sharpness of the assault of the external world upon the nervous system, reduces the quantity of blood in the internal organs, and increases the quantity in the surface. This is precisely an undoing of the effects of strong voluntary effort, which we need to escape, and is therefore a welcome addition to our hygienic means of compensating the strenuous life. In its effect, alcohol is exactly the opposite of that of tea and coffee. These increase the quantity of blood in the internal organs, increase the mental tension, and sharpen the external and mechanical mental life. The effects of alcohol are much the same, finally, as normal sleep. It has not the 1 power of creating in the body a demand for itself, and of alcoholising the tissues so that more and more is required to produce the normal effects of stimulation. The craving for excess, 


\section{PSYCHOLOGY OF INTEMPERANCE}

he maintains, is quite different. It is a demand for stupefaction, for relief from pain, and is morbid, in its extreme forms a disease. Such is Starke's view.

Whether this is a correct statement of the physiological action of alcohol would be open to doubt. But that desire for stimulation of the ego, or an effect which could be somewhat similarly described, is the central motive of intoxication, we have already seen to be true. Whether it is right and proper to select this particular means of stimulating the ego, is another question. And whether the relaxation needed in the present strenuous life demands the use of alcohol as a necessity, as he says, or whether some more natural means of counteracting strain and tension should be sought, is also a problem-a broad question, demanding an understanding of many interests and ideals. It cannot at least be solved entirely by a discovery of the specific function of alcohol itself.

As regards the nature of the craving for alcohol, whether it is an instinctive desire, or a craving acquired by the individual, there are many diverse opinions. Thomann, for example, says that the desire for alcoholic beverages is generally a physical desire, an animal lust. Baer asserts that this craving is not an instinctive but an acquired craving. Gustaf- 


\section{THEORIES OF THE IMPULSE 169}

son says that the desire for alcohol is not an instinctive habit, but it is a habit that is becoming instinctive, a form of depraved second nature. Braintwaite says that drunkards are made by the effect of alcohol upon unformed and developing tissue, especially cerebral tissue. Hughes says that the drink craving is a pathological perversion of physiological cell action, and lies in the realm of the cerebral cortex.

Day $\left({ }^{69}\right)$ says, "That there is an organic appetite for brain stimulants which, if not originally so, has become organic through unknown ages of indulgence common to man, is beyond dispute. This appetite does not anticipate for its gratification more than the primary or stimulating effects of the drugs used. It is through this appetite that the system is often exposed to an unexpected and undesired effect of the drugs used, and a painful condition of the body induced by such unintentional excess, which can in no other way be so speedily and effectually relieved temporarily as by the repetition of the excess itself, by renewed stimulation of the organs suffering, or by an obliteration of sense by a more complete narcosis than was at first intended."

Danielewski $\left({ }^{\circ 0}\right)$ says that civilised man has used alcohol so extensively, and for so long a time, that one may with certainty affirm the existence of an alcoholised protoplasm among 
drinkers, just as one finds morphinised protoplasm in cases of chronic intoxication with morphine. The organism can no longer do without it. Hence it follows that the complex of protoplasm and albuminoids is adaptable; that it is not incapable of being disturbed in its fundamental properties, and that it is reconstructed with difficulty.

The supposition of all those who believe in a specific for the cure of the craving for alcohol is that it is a physical appetite that can be destroyed by drugs. A statement of the views of a single one of these will be sufficient to illustrate the medical theories of this type. It is the theory of a specialist in the cure of drunkenness in a large American city, expressed to me in conversation. He has two specific remedies, one to remove the neurasthenic condition which he says is present in all cases of inebriety, and another to remove the craving for alcohol.. With these he claims to cure men of all ages, in any stage of the disease; and to establish such a normal condition of body and mind that, although they may drink again, they will never drink again from necessity, or because they are victims of an appetite, but only from choice. He maintains that the craving for alcohol, and the desire for stimulants of other kinds, such as hasheesh, morphine and chloral, are expressions of one and the same disease; they all have 


\section{THEORIES OF THE IMPULSE 171}

their roots in a neurasthenic condition. Other cravings, such as a passion for strong electrical stimulation, are of the same nature, the expressions of a lowered nervous tone, and a desire for something which will create activity in inactive organs.

This, or something like it, is the view that is at the bottom of those methods, often advertised, of curing the drunkard without his knowledge, by administering specifics of one kind or another in his coffee or tea. They assume that there is a specific condition of the nervous system that can be reached and corrected by an equally specific remedy which will, perhaps, change the character of the diseased protoplasm, or correct the condition of the brain, whatever it may be, which registers itself in the mind as a craving for alcohol. That these views are wrong, or at least have a very limited application, all the facts that we have presented quite sufficiently prove. Whatever the craving for alcohol may be, it is not a condition of the body craving for alcohol as a specific remedy for that condition. It is an organised habit, with psychical elements, and a history in the life of the individual connected with his other interests and impulses. There is no doubt that immediate effects can be produced upon the appetite for drink by various drugs; and that when the craving which comes 
from immediately preceding excessive drinking is so imperative, various remedies have a temporary effect. These remedies, too, when reinforced by suggestions, by isolation, and by control of the social life may effect a cure; but it is wrong to suppose that a drug can reach the heart of the intoxication impulse. It would be quite as reasonable to treat a man by merely physical remedies for a bad temper, or for being in love. Something might be accomplished in both such cases, but the root of the trouble would hardly be thus reached.

Upon another point connected with the question of a specific craving for alcohol induced by the action of alcohol itself, we have an interesting view from Forel, $\left({ }^{11}\right)$ whose authority is so high in matters pertaining to the nervous system that he must be respectfully heard. He writes,

"We do not think that man could ever adapt himself to the use of alcohol and narcotics, so that they would cease to hurt him, for the following reasons: Experience teaches that (1) the general drinking and narcotic customs incessantly augment the production and the consumption, that is, increase the daily doses which every man consumes in the average. (2) The craving which alcohol and all other narcotics produce drives to such augmentation with peculiar force where severe laws do not counteract. (3) Alcohol, and probably also all other narcotics poison not only the individual but also his sperm, the germ of his descendants. (4) The progeny of alcoholists, according to experience, are especially exposed to mental degeneration and to drinking excesses. Their ro- 


\section{THEORIES OF THE IMPULSE 173}

sistibility against alcoholic liquors is never raised, rather very much diminished."

This raises the question to what extent the craving for alcohol, having been created in an individual by the effect of alcohol upon him, can be transmitted to his offspring, as such, and thus produce a direct craving for it in the lives of an increasing number of people. That a specific craving for alcohol is ever transmitted as such seems entirely unproved, and unlikely. And Forel does not insist that it is, though others do. Alcoholic excess in the parent seemingly does affect the offspring deleteriously, and it is likely that it is the cause of several diseases now well recognised. But its effect is rather by weakening the germ in a general way than by the transmission of a craving for alcohol. Whatever weakens the germ makes it more difficult for the offspring to pass successfully through the growth stages, more likely to be affected by all external influences, and to acquire early in life such abnormal conditions of body and mind as will lead to the habit of drink, especially through the narcotic motive. But that drinking by the parent can cause in the child a craving for alcohol as such, because the germ has been alcoholised, or that the love of alcohol acquired by the parent as a mental craving can be transmitted to the child, seems very unlikely, if not quite impossible. 


\section{PSYCHOLOGY OF INTEMPERANCE}

We shall return to this point in another paragraph.

There are many theories of the craving for alcohol that take into account the psychological factors. In an article in the University Magazine entitled The Philosophy of Stimulants an anonymous writer expresses the view that stimulants and narcotics are used because they intensify consciousness; they make wider variations in life; our pleasures and pains are too evenly distributed, and it is a matter of instinct with us that we try to summate them.

Moxon $\left({ }^{72}\right)$ says that alcohol weakens common sense in its opposition to individual sense. The power of alcohol in the world is that it keeps down the oppressive powers of others and their common sense over the individual sense. Alcohol raises a man's individuality temporarily.

Monin ( ${ }^{73}$ ) says that in proportion as civilisation perfects itself man seeks in drunkenness a compensation for, and a forgetfulness of, the weariness and chagrin which result from his daily struggle for existence.

In all such views one may detect partial truths. Intoxicants do make wider variations in the emotional life; they do increase individuality, and reduce certain relations among men to a minimum, though they increase others; and they do satisfy a narcotic motive aroused by 
pain and fatigue. But no one of these views, nor all together, approximates the whole truth.

Beard ("') asks, "Why does man, so much higher than the animals in every respect, alone possess the vice of intemperance? What makes us differ from them?" and answers, "Mainly our nervous system. Man has a larger, fuller, richer brain than the lower animals, and stimulants and narcotics chiefly affect the brain; therefore man craves for them, finds rest and negative food and pleasure in them, and thus often becomes their slave. The horse does not care for alcohol for the same reason that it does not care for philosophy, because its brain is not capable of appreciating it." His interesting view we shall quote somewhat further :

"The most enlightened nations of our time are Great Britain, Germany, and the United States, and in these countries stimulants are used in the greatest abundance and the widest variety. Next to these nations in order of enlightenment and in order of indulgence in these substances are France, Russia, Norway, Sweden, Italy, and Spain. The semicivilised nations, as Turkey, Syria, India, China, Japan, South America, and Mexico, use some varieties to considerable excess, but have not so many varieties, and do not, on the whole, use as great a quantity of stimulants and narcotics as the nations who are at the head of civilisation. The purely barbarous races and tribes use at most but one or two varieties, and as a rule, to but little excess. Africa seems to have used less than any other continent.

"In civilisation the expenditure of force is vastly greater than in barbarism, because the brain, especially, is more 


\section{PSYCHOLOGY OF INTEMPERANCE}

active. To compensate for this expenditure, to retard the waste of tissue, or at least to sustain the body amid the cares, toils, and pressure incident to advanced civilisation men resort, not only to more liberal and abundant variety of food than the savages use, but also must employ a wider range of stimulants and narcotics. It would seem that the use of stimulants and narcotics in general has increased with the advance of the race. In general, also, the higher civilised races use stronger liquors and more abundantly, and since in the lower races there is less moral and other restraint, we must conclude that they are not tempted to drink to excess, that they do not enjoy the exciting effects of the stimulants as do the northerners. There is ten times as much intoxication in Great Britain and the United States as there is in Germany and France. There is far more of the grosser type. This difference is due primarily, probably, to difference in environment, climate, ete., and only seeondarily to difference in race. The English, the Germans, and the Americans are of all people the most energetic. Associated with this courage and vigour is a powerful development of some of the lower passions. They are fond of eating and drinking, and although less licentious, less artful than the French, Italian, and Spanish, they are more addicted to coarse and brutal crimes. Coarse crimes and drunkenness are twigs growing on the same stem.

"Drunkenness and the amount of liquor consumed in a given country are independent variables. England uses more liquor, in various forms, than America, but it has less drunkenness. In France the consumption of liquor is very great, but the French are by no means a grossly intemperate people. The explanation of this paradox is that national intemperance does not result so much from widely diffused habits of drinking, as from great excess among a limited number. The poor and ignorant classes among civilised nations are most given to intoxication. They are brought into the presence of the same variety of stimulants as the higher classes, and they have less moral control. Woman, everywhere, uses less intoxicants than man, not so much because her moral force is greater, but because she has loss desire for the effects of stimulation." 


\section{THEORIES OF THE IMPULSE 177}

Beard makes much of the result of climate in determining the difference of drinking habits in different nations. The effect of climate is to produce types of organisation-the effect being shown too in psychic traits. "Protestant Christianity," he adds, "is the religion of a liberty-loving, alcohol-loving people, who have a strong passion for independence and for sensual indulgence in its most active and violent forms."

This opinion need not be commented upon at length. With some change of terms, and a difference of point of view, it interprets the relation of alcoholic intoxication to strength of growth forces in much the same way as does our own view. Beard does not, however, attempt to explain the nature of this intoxication impulse, except to relate it to whatever in the nations leads to great crimes and great virtues, impulses which belong only to a high order of nervous organisation.

Another interesting discussion of the intoxication impulse is that of Reid. ( ${ }^{75}$ ) Reid is led, after a general survey of the present evolution of man, to the following three conclusions: (1) that every species must necessarily undergo retrogression unless that retrogression be checked by selection; (2) that in such a high multicellular organism as man acquired variations cannot be transmitted; (3) that in 


\section{PSYCHOLOGY. OF INTEMPERANCE}

such an organism, living amidst immensely complex and heterogeneous surroundings, the action of natural selection has been mainly to develop so extraordinary a power of varying in response to appropriate stimulation, direct or indirect, from the environment: such a remarkable power of acquiring individually fit variations that very much, indeed by far the greater part, of the characteristics of such an organism are due to stimulation acting upon this power to vary-are variations acquired by the individual, but variations which are not transmissible. At present, man's most formidable enemy is the immensely numerous class of animal and vegetable disease germs which continually threaten the safety of the race, and by ceaseless selection weed out the unfit. Moreover, immunity to one disease germ does not afford immunity to another, and each which comes into contact with man so as to cause the destruction of a sufficient number of lives, is the object of a special process of evolution.

On the mental side we find, says Reid, numerous habitually used drugs and poisons which act with sufficient violence, and to the harm of sufficiently large numbers of the race, to be the objects of special processes of selection. The chief of these poisons is alcohol. In generation after generation, alcohol is the cause of the elimination of a considerable number of the unfit in relation to it, and is the cause of considerable evolution against itself. This evolution may be in one or both of two directions: increasing power of tolerating the poison, or increasing power of avoiding it, an increasing power 


\section{THEORIES OF THE IMPULSE 179}

of imbibing alcohol without ill effects, or the diminution of the craving for it, or both. But as increasing immunity to the poison means only imbibing larger and larger quantities, evolution must be in the direction of a decreasing craving for it. This is what we should expect a priori, and this is what we do find. Races which have been long familiar with alcohol, like races long familiar with a prevalent and deadly poison, are less harmfully affected by it than races which have had little or no experience with it, and this because they crave less for it, and drink less of it. The peoples of the Mediterranean, the Greeks, the Italians, the southern Frenchman and the Spaniard, who lived for thousands of years in the presence of an abundant supply of alcohol are pre-eminently temperate. The natives of North and South America, Australia, Polynesia, Africa, Greenland, whether in Arctic, Temperate, or Torrid Zone, crave for it so much that they perish in its presence, unless we protect them with prohibitory laws. Races which lie between these extremes in regard to experience with alcohol, as the people of northern Europe, the English for example, are also between them in regard to the resistance to it.

The question as to how the craving for alcohol and other narcotics, the love of those states of mind which they severally induce, arose, can be answered in only one way. It can have arisen only as a by-product of mental evolution, a by-product which, in the absence of narcotics was harmless, but which in the presence of them is harmful, and against which, in races long affected by this or that narcotic, a secondary evolution has occurred.

This craving, according to Reid, is a specific craving. Nothing but alcohol can satisfy it. It is not transferable, so to speak, and evo-] lution against other drugs does not affect it.

Reid insists that traits acquired under the influence of such selection are not transmissible any more than are other acquired traits. 


\section{PSYCHOLOGY OF INTEMPERANCE}

The craving for alcohol depends upon consciousness, which, in turn, depends upon the presence of nervous structure. That the germ is bathed in alcohol cannot account for the habit being developed in the child.

Racial differences in regard to immunity against alcohol craving are not due to the fact that some races are by nature abstemious, nor is it due to differences in education. The craving for alcohol is an instinct, and not an acquired trait. It is comparable to hunger and thirst, or to sexual and parental love; not to a love of books or of paintings, or of country, or of a particular religious system.

It is conceivable that a man might be reared in entire ignorance of women, but in such a case, though he knew not what he desired, he would yet crave for them, and his passive desires would instantly be stimulated into activity by their presence. So a savage of a race not rendered resistant by alcoholic selection craves unknowingly for alcohol, for that state of mind which alcohol induces. Racial difference is not due in any degree, as has been maintained, to difference in the strength of alcoholic beverages in use in the different countries. On the contrary, the strength of the craving determines the degree of concentration of the alcoholic beverages.

Thie direction of the process, says Reid, has been toward a lesser craving from a greater craving, and in some cases, e. g., the English, the process has been very rapid, since side by side with individuals who have but a little craving for alcohol are found others with a very great craving, and since it frequently happens that parents who crave but little for the poison, have offspring that erave very greatly for it, $i$. e., offspring who have reverted to the ancestral type in which craving was very great, the greatness of reversion being due to the 


\section{THEORIES OF THE IMPULSE 181}

swiftness of the evolution, owing to which reversion to a not very remote ancestor results in a considerable change of type.

Races which have undergone evolution through alcoholic selection are liable to retrogression when the stringency of that selection is abated. When the innately intemperate havo as much influence on posterity as the innately temperate, alcoholic retrogression will ensue. Thus the success of every scheme for the promotion of temperance which depends upon the diminution or extinction of the alcoholic supply, or on voluntary or involuntary abstinence from alcohol, must result in an aggravation of the craving for that state of mind which indulgence in alcohol induces. The craving for alcohol is like sexual love, an instinct, not an acquired trait. The love of alcohol is born anew with each generation undiminished except by alcoholic selection. It is practically impossible to banish alcohol from our midst, and since the craving for alcohol increases with indulgence, we cannot hope that moral influence will ever result in temperance, $i$. $e$, in a moderate use of alcohol.

Why not banish alcohol as we do microbes? Because no man craves for disease, and thousands crave knowingly or unknowingly for excess in alcoholic indulgence. In the face of craving for alcohol we cannot hope to banish that poison permanently. If alcohol were abolished, the time would surely come after the race had undergone retrogression, when any law would fall into abeyance from disuse. If temperance were founded on a voluntary abstinence, the craving would eventually grow so ardent, as a result of retrogression, that no opposing traits would be sufficiently strong to counteract it. The course is to imitate natural selection and eliminate those individuals who crave for alcohol to an excessive degree, at least in so far as to prevent them influencing posterity by leaving offspring.

It is the same in regard to the other narcotics. We find that the peoples who have used them the longest are less harmed by them, and have less craving for them than the people who are not accustomed to them.

The important question is 'Does evolution against one narcotic or intoxicant effect another? It seems probable that the states of mind which these drugs induce are distinct and 
separate, just as the weaknesses against separate zymotic diseases are distinct and separate. Therefore it seems probable that a man may be strong against alcohol, but weak against opium, or vice versa, though a race accustomed to one, if debarred from using it, may go to greater excess in another, and the presence of one seems to shut out the others, especially when craving for the others has not been strongly awakened.

This interesting theory, which will be discussed presently at some length, has been reviewed in detail, not to quote it approvingly, but because, although evolutionary in its hypotheses, it is very different from the present interpretation of the facts, and because it leads to different practical conclusions. It raises many interesting problems, however, and apparently contains important truth. Before trying to point out its errors and limitations, it will be best to bring the views that have been mentioned to a brief summary, in order to have clearly in mind the divergent theories which the intoxication impulses have aroused.

There are three main types of theories about the intoxication impulse: those which try to

account for the craving for alcohol as moral deviation; those which find in it a physical appetite; and those which explain it as a mental trait or craving. There are many variants within each group. We should expect to find that in part differences of opinion are due to looking at different phases of the subject, and 


\section{THEORIES OF THE IMPULSE 183}

in part to the fact that the craving for intoxicants is a complex impulse, and no one, perhaps, has seen the whole of the problem.

The physical theories of the craving for alcohol are especially inadequate. The facts already noted perhaps sufficiently criticise these views, but two aspects of them need to be emphasised: that is, the view that the craving for alcohol in the individual is due to the effect of alcohol upon the tissues, and that this craving can be transmitted to offspring. The truth involved in these views is based upon three facts. Certainly tomany, liquors are pleasing to the taste, and an appetite for alcohol may be due to a taste craving. But that such craving is not as a rule strong, and that it is often absent in the drinker, is certain. If alcohol is a food, it may be sought like any other food. But this does not account for the excessive use of it, and its specific effects are not allowed on this theory to account for any of the impulse to its use. The second fact is that alcohol taken in excess is capable of producing at least temporarily a longing for more. But that alcohol can of itself affect the protoplasm of the body so that thereafter it is changed in character, and a permanent craving which constitutes the individual's weakness for alcoholic drinks, is thus created, appears to be quite disproved by the facts. No such fixed craving exists; it is a 


\section{PSYCHOLOGY OF INTEMPERANCE}

very adaptable impulse, it depends for its existence upon social incitement and the presence of alcohol, even in extreme cases, and shows other clear indications of not being such a craving as the theory of alcoholised protoplasm asserts.

The view that the craving for alcohol, acquired by the parent, may be transmitted to the offspring takes two forms. The truth-and this is the third fact upon which these physical views are based-is that alcoholism of the parent may indirectly cause degeneration and alcohol craving in the child, but not directly. The alcoholised germ may become the degenerate child because it is weakened by the effect of alcohol, but that it can receive thus a specific craving for alcohol seems altogether improbable, and even impossible. Even less warrant is there for the view that the germ may be impressed by the parent's acquired craving for alcohol as a mental state, in such a way that the child inherits a craving. That a craving for alcohol is in-

$\int$ herited, therefore, is not proved, and the theory is not in accordance with the facts. Probably no one would now deny that alcohol may so affect the parent as to cause degeneracy and disease in the offspring, and thus indirectly produce a tendency to many abnormal habits including excessive use of alcohol, the indulgence in which temporarily and artificially relieves 


\section{THEORIES OF THE IMPULSE 185}

pain, or satisfies an excessive and abnormal craving for excitement. It is probable that the offspring of the opium user is quite as likely to succumb to a craving for alcohol, as is the alcohol drinker's child.

Cases in which there is said to be a craving for alcohol due to the parent's intemperate habits need careful scrutiny before they are pronounced to be thus caused. The child may certainly become addicted to alcoholic excess like his father, because he inherited his father's temperament, including his liability to excess in this and perhaps in other ways. This point needs to be emphasised, and also that such a temperamental weakness may be hereditary with very little likelihood that the child will become a. drunkard. The fear of inheritance is a harmful attitude of the public mind, and helps to perpetuate the belief in the fatality of the drunkard's career, quite in contradiction to the facts. A few cases will illustrate the psychological points that we wish to enforce.

The following case was related by a physician:-A drunkard had two daughters, both of whom inherited from him a craving for alcohol. One drank, at first moderately, and then to excess, and finally died from the effects. The second has never tasted alcohol, but testifies that she has a craving for it. It is difficult to understand how one may be sure of having a craving 
for something which is totally outside one's experience. Suggestion and fear account for such a belief, and the foundation in feeling is probably a general dissatisfaction or longing, or nervous discomfort, which thousands of people have who have no alcoholic heredity. Probably the second daughter in this case was no more likely to become a drunkard than a great many others of nervous temperament, who have no alcoholic heredity at all.

Another case will show how easily these cravings for alcohol may be misinterpreted. A man accustomed to careful introspection writes as follows :

"I have never tasted alcohol in any form so far as I know, but often, especially on going by a saloon, I have a strong desire to go in and get a drink. The sign, 'Frank Jones' Golden Ale' appeals to me, and the picture of the foaming glass has a fascination for me especially on a hot day. Now I haven't the slightest idea what 'Frank Jones' Golden Ale' tastes like. I may add that there is no history of alcoholism in my family.'"

Later this man reported that he had drunk a glass of ale and did not like it at all. If he had ever had the alcohol habit, or if there had been a history of it in his family, he would have concluded perhaps that his longing was a deepseated craving for drink. 


\section{THEORIES OF THE IMPULSE 187}

Another case will illustrate a different side of the question. A very normal man of forty years remembers as a child of not more than five having once drunk something from a peculiar looking bottle. He remembers distinctly noticing that the people present exchanged significant looks and were laughing at him. He remembers liking the taste, and afterwards looking many times for the bottle in order to have more of the drink, which he now knows was cherry rum. As he grew up, remembering this childish craving, he for years believed that he had an inherited taste for alcohol, as there was a history of it in the family, his grandfather having been a very heavy drinker. He has since used alcohol moderately and has had no tendency whatever to fall a victim to it.

The simplest explanation of the inherited craving for alcohol is that it does not exist at all, but that various longings are interpreted as such. The facility with which alcohol habits can be exchanged for other drug habits, the effectiveness of cures which act upon the mental processes, the abrupt cessation of the craving when alcohol cannot be obtained, all point to a single conclusion: that the craving for alcohol is not a physiological craving, but a complex mentaI state, that it is not as such transmitted, and that much that is interpreted as a craving for alcohol is not this at all, but is a more gen- 


\section{PSYCHOLOGY. OF INTEMPERANCE}

eral craving for various forms of experience.

Perhaps the strongest evidence against the view that alcoholised protoplasm is the physiological basis of the craving for alcohol, is furnished by the abundant testimony that the young drinker is far less amenable to treatment than the old drinker, which could hardly be the case, if a slow process of poisoning produced the craving. The sudden cures, especially the psychic cures, offer further evidence on the point. The widespread belief in the deep-seated physical nature of the craving for alcohol has had in the past a pernicious effect; for the belief that a habit is incurable serves, more than anything else, to compel its continuance, while the effect of the opposite belief, that the habit may easily be broken, or that a cure has been effected, often constitutes the whole cure, even in old and severe cases.

Such a view does not of course deny that there are physiological substrata in the habits of intoxication as in all other experiences. Alcohol used in excess certainly does make demonstrable inroads upon the finer structures of the brain, and these changes are supposedly the basis of weakened will and lessened reserve, and other protective attitudes of consciousness. Nor would a psychological view of intemperance rule out of court such hypotheses as those of Campbell, who claims that stimulants are nor- 


\section{THEORIES OF THE IMPULSE 189}

mally present in the body, either created as byproducts of metabolism, or present in the food, that they are utilised in the body, and are involved in the feeling of well-being and ill-being; and that when the normal stimulants are deficient artificial stimulants are craved. We must indeed assume physical and chemical factors in all mental attitudes, the normal no less than the abnormal. But no such hypotheses afford an adequate explanation of intemperance.

A corollary of the physical-craving theory of the alcohol habit is the oft-accepted statement that the effect of alcohol upon the system is to produce such a condition of the tissues that greater and greater quantities are required to produce intoxication, and there is a more and more imperative physiological need. This is by no means proved, especially in cases in which there are even short periods of abstinence. Waugh denies the statement that drug users increase the dose because it takes more and more to produce exhilaration. He says that all whom he has questioned have confessed that they increase the dose because they desire more of the feeling. The same was found to be true in some of our cases. Some say that less is required to intoxicate as the habit progresses. In cases in which drinking is steady, day after day, however, there seems to be within limits a capacity for consuming larger and larger quantities 
with comparative impunity. In cases of relapse after cures by the Keeley and other methods, sudden death is sometimes caused, it seems, by the inability of the system to consume quantities of alcohol that were readily disposed of while the habit was steadily maintained.

Those theories that claim for the alcohol craving a psychic origin seem nearly all to have hit upon truth, but only partial truth. So long as they cleave to generalities and speak of an instinctive craving for alcohol, or say that the craving has become a form of second nature, and make similar formulations, they need little criticism, since they offer little explanation. There is no doubt that the claim that habits of intemperance have been perpetuated because of the pain in the world, contains truth. But this is only a half truth, for pain is but one motive, and accounts for but a part of the world's drinking. The theory that alcohol is used because it causes wider variations in life, which is otherwise too monotonous, expresses vaguely an important psychological truth, as does also the view that alcohol changes the relation between common sense and individual sense. Beard's theory of the close relation between high mental development in a race, and a love of stimulation also accords with a part of the facts, and roughly describes one motive of intoxication. Somewhat more precise is Starke's 


\section{THEORIES OF THE IMPULSE 191}

view that alcohol stimulates the ego, the inner individuality with its sentiments and passions; and by strengthening this activity makes attention to external things - to the mechanical and acquired parts of experience-less intense. Put into a more general form these views mean this: Alcohol serves the purpose of relaxing or inbibiting the more individual experiences of a man, and of stimulating the emotional life, which is the deeper and wider life.* It thus enlarges the individuality, and allows the feeling life and imagination such scope as might be realised in a life before the advent of a civilisation which makes the individual narrow and special. That is, alcohol serves to widen the experience, to make life more social, and to produce states like those in the growth periods of the individual, when he is dominated by the feelings and ideals of his race, and is not hampered by the details and necessities of personal achievement. The life of purpose and ideas is aroused, and outlook is stimulated, while the life of fact is relatively

* From an investigation of the motives for drinking made among professional classes for the Committee of Fifty the conclusion was reached that drinks are used mainly for their effect upon mental action, especially upon the emotions, and that they are sometimes used from a special desire to increase the intensity of consciousness, but more often for their sedative effects-and that the whole strength of the liquor traffic lies in the weakness of human nature on the social side.

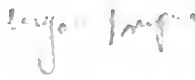


diminished. The meaning of life is artificially widened and deepened.

As to Reid's view that the craving for alcohol (which is equivalent for him to the craving for intoxication, because he claims that every dose of alcohol produces some degree of intoxication) is a product of mental evolution, and is a specific craving for alcohol, satisfied by nothing else, and controlled only by a process of evolution which is directly against it as an isolated factor in man's development,-all the facts and interpretations of the preceding chapters oppose it. That it is in a sense an instinct, that it is a product of, or is related to, or is a part of, mental evolution would be admitted, indeed, asserted; but that the craving is a specific craving for alcoholic intoxication would be denied. If wrong, such a view leads to very erroneous generalisations about the course of mental evolution, and to decidedly wrong views of the practical problems of intemperance. The error consists in asserting a likeness between the craving for alcohol and a zymotic or germ disease. If the craving were thus specific, and were general enough, and could be stripped of some of its economic and other complications, evolution would perhaps act toward it as Reid maintains. But evidence is conclusive that it is not such a specific craving, that it is plastic, and a part of a more general desire, which ap- 


\section{THEORIES OF THE IMPULSE 193}

pears in many forms, and can be satisfied in many ways. Any process of evolution which weeds out those defective in control generally will help, we believe, to eliminate the alcoholic victim, and would at the same time prevent a nation becoming susceptible to the inroads of any habit. Besides, evolution does not act thus precisely upon the craving for alcohol. The effects of alcoholic excess reach out so widely upon those who do not possess the craving as such, but who are made liable to it through the hardships which it inflicts upon them indirectly (as in the case of children of inebriates, who are not eliminated and who tend to spread the habit), that there can be no such uniform reduction as Reid maintains. Independently of inherited effects, too, whole classes of society are made poorer and distress is perpetuated among them by the use of alcohol, thus keeping alive the narcotic motive for its use rather than diminishing it. Unless at the same time the poor as a class in society are being eliminated by evolution the craving for alcohol is not being checked by evolution, for it certainly persists wherever poverty occurs in the midst of wealth. Nor among higher classes does the craving die out by inheritance of lesser craving, for those who, judged by the only criteria we have, inherit little craving as such appear readily to acquire the habit, and so start another chain of effect 


\section{PSYCHOLOGY OF INTEMPERANCE}

and cause; while, too, new motives and favouring conditions are continually produced.

Even though it were true that in nations which have long been accustomed to alcohol there is less craving for it than in nations in which the habit has recently been acquired (as does not seem to be the case) this would not indicate that the length of experience is the cause of the diminished craving. Older races have many characteristics of old age, among them diminished exuberance of feeling. The history of drinking among civilised nations shows that the elimination of the craving for alcohol has not been a uniform process. As we have seen, times preceding eras of high culture have been times of gross intemperance; temperance has come with the highest culture, and then intemperance again as the nation declined. Lower races which have long been accustomed to native alcoholic beverages perish when brought into contact with the stronger drinks of civilised men, showing that their long acquaintance with alcohol has not eliminated from them the dangers of excess, when they become influenced by the social habits of the white man. It is well known that Europeans of the lower classes, especially Italians, who, Reid says, have not a strong craving for alcohol, on coming to America readily succumb to the drinking habits of the country. 


\section{THEORIES OF THE IMPULSE 195}

There is nowhere in the history of drink an account of the sudden introduction of alcohol into a civilised country previously unaccustomed to drinking. In that case we should expect, on such a theory as that of Reid, the most disastrous effects, for no degree of civilisation would in itself be in the least a safeguard against alcohol in the absence of a long period in which selection had been at work eliminating the craving. A good example of this, however, on a small scale, is to be found in the case of families who because of moral ideals have been abstainers for many generations. On Reid's theory we should expect that the descendants of these would be weak in the presence of alcohol. This does not appear to be true; in fact quite the opposite conclusion is warranted. A few generations of moral tradition in a family fortify its descendants against excess and immorality. The sudden introduction of alcohol into an abstinent nation in such a stage of growth as that of our own country at the present time, would probably not, as Reid says, result disastrously, for the reason that selection has already produced, in connection with general advancement of civilisation, those qualities of control and those ideals which antagonise all forms of destructive habits, alcoholism among the rest.

Diminution of the craving for alcohol has 


\section{PSYCHOLOGY OF INTEMPERANCE}

come about, if at all, not by a process of evolution working against a specific craving, but by a broad movement in which lower impulses have been transformed into higher. Intoxication once regarded as a religious duty quite generally among uncivilised nations, has come after centuries to be regarded as sinful. Though ideals of temperance differ greatly among civilised nations, it can be said that there is an increasing and spreading interest in temperance, and even total abstinence; and that the motives leading to intemperance are held in check by this moral ideal. This motive is a slow growth, parallel to the impulse which it holds in check; and by inhibiting the intoxication motives it creates a tension favourable to higher development. The central impulse of temperance ideals is the idea of social service. Those who drink to excess waste and pervert enthusiasm, and become useless members of society. As civilisation increases the individual must more and more become a link in a chain of co-ordinated events. He must control his activities and be controlled; he must turn the raw material of his enthusiasm into a product. Therefore the ideal of control, both inner and outer, develops, the one expressed in law, the other in moral conscience. The spirit of intoxication, the force and energy of which it is an expression, is recognised to be a precious asset 


\section{THEORIES OF THE IMPULSE 197}

of the race, and our efforts are directed to turning the lower, more immediately expressive, and less organised forms of enthusiasm into the higher. That which remains unproductive, which does not inspire useful conduct, is socially condemned, and religious sanctions are sought for so condemning it. Other motives enter, for example the increasing respect for the integrity of the self, which helps to create public sentiment against all states in which the individual does not rationally direct his conduct. The obvious result of intoxication in inciting to other undesirable acts is another motive of temperance. The narcotic motive, the effort to escape pain and fatigue is condemned, in proportion as pain and fatigue are seen to result from and to favour the continuance of the normal activities which society holds in highest esteem. Every individual is directed to bear his part of the pain, and to turn his restlessness and distress, as forces, into useful channels. Among some classes of society these ideals become a demand for total abstinence, enforced by laws prohibiting the sale of intoxicating liquors. The tendency is to condemn all drinking of alcohol, in part because of a theological ideal which has condemned all pleasure as sin. With it goes a tendency to discountenance all the luxuries of the wealthy classes. In temperate drinking is found a danger of drunkenness 


\section{PSYCHOLOGY OF INTEMPERANCE}

and an example which leads to intemperate drinking on the part of the lower classes, or by weak individuals of the higher classes; and so gradually an ideal of complete abstinence has spread widely. This ideal tends to be supported also by an increasing conviction that alcohol is harmful to the body. We must leave to the practical part of the discussion to judge the probable future of this ideal and the attitude toward it which should be taken from the standpoint of the facts about alcohol and intoxication. 


\section{CHAPTER $\mathrm{X}$}

SUMMARY OF FACTS AND INTERPRETATIONS

Having come by several different methods to various conclusions about the nature of intoxication and the intoxication impulse, it will be well to cast a retrospective glance, in order to know how these interpretations may be brought together into a general view, and to prepare for a study of the practical problems of temperance and the use of alcohol generally. The interest is not in working out a consistent psychological theory, which would be tempting if the purpose of the study were different; for the facts about intoxication raise many interesting questions about the nature of instinct and emotion, and the laws of mental development in the individual and in the race. Neither is the purpose to formulate a single definite principle from which certain practical conclusions may be deduced. It is rather to organise the various facts and interpretations in such a way as to bring the psychological view-points into the foreground, and show the part they may take-combined with other scientific factors of the problem, and with 
200 PSYCHOLOGY OF INTEMPERANCE

practical and common-sense considerations, and the results of experimentation and experience -in attaining a broad and sane outlook upon the questions at issue.

If we are to deal in a practical manner with habits of men, it seems as though the first important work is tofunderstand the motives upon which these habits are based, ${ }^{2}$ their history in the individual and $d^{3}$ in the race. At the same time we may profitably investigate our own moral judgments, and trace their historywe must understand the human passions with which we deal, both those which we try to control, and those that motivate the ideals toward which we wish to bring the conduct of others, before we shall be equipped to proceed with the highest intelligence. In other

words we need to know why men are impelled to drink, and why we wish to restrain them. In studying such a problem as intemperance, knowledge about the impulses which lead to intoxication must be supplemented by knowledge about the state of intoxication itself in all its degrees and forms. For how can one undertake to control, abolish, or judge a thing without knowing precisely what its nature is? If it is abnormal, a disorder or poisoning of the body, a temporary insanity, we must know how the normal functions are related to it, just as we must discover what normal impulses are most 
nearly related to the craving for these conditions, which is the underlying cause of intemperance. These are the lines upon which our investigation has progressed.

A study of the intoxication motive in animals showed that even in the lowest forms of life intoxication can be induced; and that at least its physical phenomena are much like those of human intoxication. Animals can acquire the habit of intoxication, but the mental aspects of their habit cannot easily be investigated. Whether they ever form so complex an association as to seek a drink which is in itself un- $\checkmark$ pleasant for the sake of a remote mentai effect, seems quite doubtful.

Closely connected with the intoxication states induced by alcohol are certain states of exaltation related to the play and mating habits of animals. These states appear to serve the purpose of making dynamic various actions of the animal, especially the sexual, and they also seem to assist in bringing the nervous system to complete development, and to stimulate functions that are later, perhaps, to be called upon to produce effects remote from the purpose of their origin. It is likely that both the mechanisms involved in producing these states of ecstasy and the motives which induce them have originated, in part at least, in connection with the sexual erethisms. Later, as we pass to higher forms 
of animal life, and to man, we see that these old mechanisms still perform a part, and give to many actions and desires their motive power. These mechanisms, once special and definitely purposeful in form, when detached from their original purpose may become the basis of very general activities and desires.

Every trait of the human species has a double history: in the race, and in the individual, and must be studied in both its aspects. Turning to the history of the intoxication impulse in the race, we find a long and complicated story. The custom of using alcoholic drinks is polygenetic and nearly universal among tribes and races. Intoxication has played a great part in the religious and social life of primitive peoples. There is evidence to indicate that it was first induced for religious purposes, and in common with other forms of exaltation of feeling, was put to an important religious use. It enlarged man's conception of the supernatural and divine, and stimulated belief. Shamanism, the first developed religion, was founded upon intoxication, and spread as a cult over all the world. Every important event in the life of the savage has been celebrated by intoxication, and especially in the social life, alcohol has performed a service. Its function has been to widen the social life, to assist in the amalgamation of tribes, and to foster co-ordinations within 
social groups. By stimulating belief it has made all socialising influences more effective. Indeed it is difficult to imagine what the social and religious life of primitive and savage man might have been without alcohol.

Excessive and infrequent or periodic intoxication seems to have been the usual form of drinking among uncivilised tribes. Drinking was carried on for a purpose, was always connected with an idea, and drinking of alcohol as a beverage was a late result. Temperance arose first as the regulation of the rites of intoxication by custom and law, rather than from moral restraint. Woman everywhere has used alcohol to a less extent than has man, not only because alcohol has been prohibited to her by law and custom, but because her habit of life is less erethic, her tasks therefore more monotonous, and less subject to wide variations and sweeping rhythms: in other words because the intoxication impulse or motive is weaker in woman than in man. In civilisation, however, she readily succumbs to other motives for drinking, and acquires narcotic habits.

Examination of various activities of man, in which states of exalted feeling are sought, shows that the craving for periodic excitement is deepseated. Alcohol affords to man one means of many, normal and abnormal, of breaking away from his routines and controls, and reaching 


\section{PSYCHOLOGY OF INTEMPERANCE}

new levels of feeling. There is a natural tendency on the part of the young to seek excitement and all exalted states of feeling. The erethic habit, and craving for, or instinctive seeking of, erethic states is a normal and necessary aspect of growth, favoured by selection because it assists in perfecting and increasing the powers of the organism; because it creates a high tension of feeling, which is the condition of effective action, and is an exercise of all the higher enthusiasms. So both endurance of high tension and the desire to produce it have increased as the nervous mechanisms have become more complex. Thus the sexual erethisms, intoxication states of various kinds, excitement of play, states of second breath, ecstasy, religious fervour, social intensity, belief, enthusiasm, and the intensity of mental action which is finally controlled and expressed in long-sustained attention and interest, are interpreted as psychological kindred, all connected, it is likely, by the common utilisation of the same mechanisms of the nervous system, and by participating in a common impulse or instinct to induce high intensity of mental activity as a mode of mental development.

At adolescence all these intoxication motives become intensified, and their relation to growth becomes clear. The whole period is best characterised as dominated by the intoxication mo- 
tives, and the strength of these motives in the life of the individual, and their plasticity and educability, is the test of capacity for growth, and the basis of all future interests and enthusiasms. The love of alcohol intoxication is but one expression of a plastic motive and capacity of the nervous system, a motive that is deep-seated and fundamental. When growth is normal, the lower, unproductive enthusiasms become transformed into higher, productive and organised activities, and the individual transcends the dangers of intemperance and other lower forms of expression of the intoxication impulse. Both in the individual and in the race the lower, more general, and cruder forms of intoxication precede the higher and more controlled.

Continuing the survey of the genesis of the intoxication impulses in the race, their relation to mental development and social organisation becomes still clearer, as also does the relation between the growth of the individual and of the race. We find that the intoxication impulses are strongest in the dominant races, and that they are always more intense in periods of rapid growth, especially at times just preceding the greatest intellectual activity. The cult of Dionysus in Greece is to be interpreted as a worship of the creative force, an expression of the longing for a larger and more abundant life. 


\section{PSYCHOLOGY OF INTEMPERANCE}

At the time of the Renaissance the excessive intensity of the intoxication motive again indicates the onset of a period of accelerated growth. Now there is a change from outer to inner control, and for a time no control at all. The emotional life is widened and deepened, new enthusiasms are created and the crude growth forces are at last brought under control in a new social era. The rough virtues and vices that mark the growing periods of the dominant races become transformed. The warlike spirit and intemperance go together, and both are expressions of mental and physical virility.

As national life becomes more intricate the intoxication motives are found to be complex. Immigration toward centres of greatest progress ensues, increasing the heterogeneity of life; there is more flux among social classes; higher motives act side by side with the low and abnormal motives; and whenever growth ceases, and degeneration sets in, whether in small or large groups, and the number of abnormal individuals greatly increases, the narcotic impulse arises. This is the longing to escape from pain, to seek relief in inactivity and rest; it is a turning backward away from the strenuous life, or is an effort to arouse flagging enthusiasms, and bring back pleasures for which there is no longer physical or mental strength. 
When the narcotic motive becomes general or widespread growth has ceased. In all great nations, centres of stagnation form, and tend to spread, unless the life be replenished from sources outside the stagnant group. Both among the idle rich, and in the hopeless poor, such centres of development of the narcotic motives are to be found. They are the expression of old age and disease in a nation.

Thus the intoxication motives in the individual and the race run parallel to one another. In the play of normal childhood, in the exuberant feeling of adolescence, in its crude forces and pioneer spirit, we see the motives that lead to maturity and a broad, full life, paralleling the periods of growth in the race. Old age in both brings in the narcotic motives, and in both, whenever there is interference with the normal processes of growth, when there is premature strain or disease, abnormal motives may creep in, in the midst of progress, and old age ensues before childhood is past. Whenever the growth force is weakened, premature motives of pain and fatigue take the place of the normal intoxication impulses.

Such strong motives as the intoxication impulses could not have failed to leave their impress at every step upon language and literature. The origin of wine is a frequent theme in primitive philosophies, in folk lore and in pop- 


\section{PSYCHOLOGY OF INTEMPERANCE}

ular belief. Its remarkable effect upon the language, the extraordinary number of synonyms for intoxication, especially in popular speech, show how profoundly this motive has affected thought and feeling, and indicate what a powerful undercurrent it has become whenever it has failed to be transformed into higher motives. In the literature of drink the two main drinking motives, those of intoxication and of narcosis, are expressed in an exaggerated form in a way which shows many interesting bypaths of human thought. In medicine, too, in the doctrine of stimulus, the intoxication impulses can be traced, influencing the course of practice, and causing the disproportionate use of drugs that directly affect consciousness.

The stimulant-narcotics, though they vary much in their effects from one to another, all are similar in their power of both exciting and depressing the activity of living tissues. This is true, in general, both of large and of small doses, though precisely the physiological mechanism of these effects is the subject of much difference of opinion. Some physiologists deny altogether that alcohol has in a true sense a direct stimulating effect upon the tissues, and others assert that its narcotic effects are for the most part due to redirection of energies, and are not the result of a narcotising of the tissues themselves. But whenever either 
motor or mental aspects of the effect of alcohol are tested, the typical course of excitation followed by depression is usually found. Experiments made with small doses of alcohol to determine its effect upon various motor and mental processes show, typically, slight improvement followed by depression. No very large amount of alcohol can be taken without lessening appreciably the amount of mental work that can be done in a given time.

A state or process of intoxication caused by large doses of alcohol is similar in nature to the effects of the small dose, but is more complex. An alcoholic intoxication is essentially a succession of emotional states, at first an exaltation of feeling, and then depression. Normal limits, both of pleasure and pain, are passed, and with the widening of the emotional field, is an increase in the activity of associations, or at least a greater freedom in their expression. In the stage of exaltation there is a sense of experiencing more abundant life, social contact is widened, belief is quickened, and the external world loses its control over the mental processes. Activity is determined from within. The individual feels a glow as of an ideal life. Life seems for the time richer in meaning, there is a definite moment when a sense of lost control is experienced, and the mind begins to flow free of its acquired inhibitions, 


\section{PSYCHOLOGY OF INTEMPERANCE}

inner and outer. This feeling of freedom and of expansion of the individual is the condition sought in intoxication, and is the source of the craving for the state.

What the physiological basis of the series of mental changes in intoxication is, cannot as yet be determined with certainty. Alcohol affects different tissues differently, both in order of time, and possibly in the character of the effect. We may suppose that stimulating effects, narcotic effects, the results of the release of lower mechanisms by the depression of the higher, and the effects of redistribution of energies and tensions go on together. There is evidence to indicate that those functions most closely connected with pleasure and displeasure are singled out by the alcohol for the greatest effects, and that this change in the physiological bases of pleasure and displeasure constitutes the central change in intoxication. The result of the alcohol, however its work is accomplished, is to bring into activity a wider range of nervous mechanisms, under less control from the organised habits of the individual than in the normal state.

Two general types of organisation favour the acquisition of habits of excessive or morbid use of alcohol: the undeveloped type, and the degenerate, over-sensitive, or otherwise morbid nervous organisation. The low organism can- 
not transform lower into higher enthusiasms; it is over suggestible, and its conduct is determined by least resistance, by the environment with which it comes into contact. The degenerate is subject to excessive use of alcohol because of ill-balance of the nervous forces. $\mathrm{He}$ is more likely to drink from motives of pain and fatigue, and to seek narcotic effects of drugs. True dipsomania is best explained as a reversion to primitive physiological rhythms, due to the instability of higher strata of inhibitions.

A study of cases of inebriety shows that in one of its motives alcoholic excess is an adolescent phenomenon. It grows out of a normal and universal desire for the largest and most intense life, and becomes established as excess or disease, because of imperfect development of the individual, due to inner defect, or outer circumstance, or both.

Contrary to popular belief a close study of the inner life of the inebriate fails to show, in the great majority of cases, anything that can be called a craving for alcohol, especially as a physical need, induced by alcoholic excess. The habit is social in expression, and is continued only under the influence of social suggestion. The only chronic craving for alcohol which can be detected is in the neurotic case, in which general distress, fatigue and pain are quite likely to 


\section{PSYCHOLOGY OF INTEMPERANCE}

be mistaken for a specific need of alcohol. But even in these cases the craving for drink is highly plastic, and subject to mental control. The craving for alcohol is a complex mental attitude; it has its roots in the social life; and it is readily changed into other forms of desire. It is strongest and least susceptible to treatment during the most active decades of a man's life, and is liable to sudden cessation or easy control at the beginning of senescence. It is not a thing in itself, but is closely related to all a man's interests, social and even religious, and is renewed each day by his most natural and necessary associations.

The narcotic motive seems to reach its height later, in the early thirties, when there is the first decline in interest in life; it is more abnormal, likely to remain longer, and to retain hold of a man even into old age. It is indeed essentially an instinct of old age, a longing for relief from pain, for rest, and for return to a pristine state of health.

The great number of theories about the intoxication impulse and the many points of view from which it has been observed show both its complexity and the intricate relations of it to normal life interests. Some have tried to explain it as al physical eraving, normal or abnormal, as an effect of alcohol upon the protoplasm of the body. LIt is called a second nature, an ac- 
quired habit, an instinct in the making. 3. Some have found in it only a desire to escape pain, others a wish to break up the monotony of life, a desire to stimulate the ego, a by-product of mental evolution, and a specific craving.

Many of these views were found to contain partial truth, and to apply to some phase of the question; some only to the extremely morbid case, or the special condition of extreme intoxication or long-continued, uninterrupted use of alcohol. Particularly that view which regards the craving for alcohol as a physical craving or a specific mental craving was found to be untenable, and out of harmony with all the facts. There is little evidence that anything like a specific craving exists, or that a specific desire for alcohol can be transmitted to offspring as a result of the habit of the parent. These erroneous views have done much to prevent the right practical attitude towards the problems of temperance. The intoxication motive cannot be understood until it is seen in its normal relations. It is not a specific morbid craving but one form of expression of a general attitude, connected with mental evolution. Out of the craving for states of high intensity of consciousness has been developed mental power which has been applied in many directions, and which; under control and organised, is the tension that underlies long-continued effort and 


\section{- 214 PSYCHOLOGY. OF INTEMPERANCE}

work. These states, and the impulse or instinct to attain them, have therefore been favoured by selection, and types of nervous organism have been produced in which there is both capacity for strong, intense action, and a desire to exert the forces of the organism to the utmost limits. This method of mental evolution has necessitated stages of crude and uncontrolled force and enthusiasm, and has been the means of introducing morbid types and diseases into the world. The craving for intoxication is a desire that can be satisfied in many divergent ways, and the practical problem of its control consists, as we |l shall see, in bringing its lower expressions to higher forms. Evolution is not directed specifically against the craving for alcohol, either to produce or to eliminate it, but is producing a certain type of nervous mechanism in which there is a balance between desire and control. Any individual not capable of being brought into the wide area of variability that is normal, tends to be eliminated; but there is no evolutionary process directed against alcohol as such, and in a sense the presence or absence of alcohol is an unessential factor in the present evolution of man. Not alcohol itself, but the motives for its excessive use must be attacked.

Temperance grows out of an ideal of social service and individual efficiency, and movements toward it and toward total abstinence must be 


\section{SUMMARY OF FACTS}

tested by fitness to further social welfare. To attack the use of alcoholic drinks as sin, without considering concretely the nature of its sinfulness, is a narrow service to the ideal, and must be superseded by more rational and more positive endeavour. 



\section{THE PRACTICAL PROBLEM}





\section{CHAPTER XI}

THE PRACTICAL PROBLEM

The practical questions of intoxication and the use of intoxicants and narcotics generally, centre about three problems, which, though distinguishable for the purposes of discussion, must be studied in the light of the same general principles. To derive a theory and general standpoint for the study of the practical problems has been the main purpose of all the preceding study. We have not tried, it is true, to deduce from any fundamental position or law the principles which explain intoxication and appraise its moral worth, but have approached the subject from various points of view, and have followed facts to see whither they would lead. The result is not a definite theory or single principle, but a general view of mental and physical development, a picture of nature's scheme of production of the higher mental traits from the lower, within which the place of the intoxication motive has been traced.

The final task is to approach the practical questions with these view-points in mind, not trying to deduce practical consequences directly, 
from them, but using them as explanatory principles to broaden the vision of practical sense and prudential act. Thus we may perhaps prevent,radical and shortsighted conclusions, temper the fanaticism of the narrow reformer, and see the problems in the breadth and perspective in which they must be studied, if we are to act rationally.

The three questions of practical public interest, about which most of the problems of temperance centre are:

(1) Education of the child with reference to temperance and the use of intoxicants generally. This includes the problem of instruction in the physiology and hygiene of alcohol, ethical teaching, and other resources of the school in leading children toward an ideal of a temperate life.

(2) The problem of the saloon. In this connection appear the problems of legal enactment in regard to the manufacture and sale of liquor, the questions of public approval or disapproval of all forms of drinking; and considered broadly, estimation of the evils of club life, and of various organisations that favour the increase of intoxication; problems of public recreation and hygiene; of the condition of the working man and provisions for the welfare of the lower classes. The problem spreads out broad- 


\section{THE PRACTICAL PROBLEM}

ly into questions of social ethics, hygiene and public education.

(3) The care, control, and cure of the excessive and abnormal user of intoxicants. Here enters the problem of punishment for drunkenness, estimation of various methods of cure of intoxication habits, questions of the prevention of hereditary influences, and others that arise in controlling the acts of the excessive drinker.

It is not within the scope of this volume to follow out in detail all these problems. The purpose is to apply certain general psychological standpoints to each of these questions, in order to suggest a basis from which they may be discussed. It is, indeed, rather in keeping problems open and experimental than in arriving at fixed conclusions that such principles have value. 


\section{CHAPTER XII}

THE SALOON AND THE CLUB

After such a preliminary study of the facts about alcoholic intoxication, and the impulses which motivate it, the problem of the saloon can be approached with more confidence than from the purely moral point of view. Like all social problems it is complex. Scientific conclusions alone cannot decide its questions. Science can explain the situation, and suggest ways and means of controlling it. In actual practice there are many considerations of expediency. Many interests are involved in the saloon.

The saloon is a situation which must be observed and analysed before it is dealt with practically. All its elements must be taken fairly into consideration. Both its ethical and its social aspects must be studied, both its practical and theoretical problems. It must be regarded from the point of view of economics, of physical and mental hygiene, of medicine, of biology, and of psychology. All this makes a formidable programme, and as yet the evidence is all too meager. But meantime we must do something about the saloon. We must vote for 


\section{THE SALOON AND THE CLUB 223}

or against it, and must enact laws of one kind or another or refrain from enacting them. We take, therefore, whatever scientific evidence there is at hand, exert our common sense, and try to gain the largest view possible of the situation. That, it can be claimed, is not commonly attempted. Opponents and advocates of the saloon there are in plenty, but there is too little of painstaking study of all its aspects.

Four questions can be raised about the saloon, about which we can reasonably expect to obtain fruitful information from the psychological point of view. These are:

1. What evils are caused by the saloon, or are most intimately connected with it?

2. What normal elements, if any, does the saloon possess? What useful function, if any, does it perform in society?

3. What is the effect, in regard to these evils and possible elements of good, of abolishing the saloon?

4. Is there anything which may be substituted for the saloon, which shall have none or less of its evils and also contain positive elements of good?

The form of these questions, it is true, indicates certain prejudices. Evils are recognised, and possibility of good, in advance of examining the evidence. The former can scarcely be denied; the latter, we are prepared and enjoined 


\section{PSYCHOLOGY OF INTEMPERANCE}

to look for, after considering the place of the intoxication impulses in mental development.

What are the evils of the saloon? Many will say that these are so obvious that they will need no enumeration. The saloon is an unmitigated evil and nuisance, the creation of the lowest element in man's nature, the tool of base interests, and the only remedy is to destroy it root and branch. What are the evils which so condemn it? Men waste both time and money in the saloon. They neglect their duties of home and business, and thus inflict hardship upon their families. By making a man poor, it lowers his , social standing and that of his family. ,Poverty brings disease through starved bodies and starved minds. The man himself injures his

、 health, blunts his moral sense, acquires disorders of the whole being which he may transmit in one way or another to his offspring. These evils spread beyond the individual and his family; the man who drinks to excess produces conditions in his environment which perpetuate the evil of drinking. The saloon creates thus an atmosphere of low thought and action; and keeps alive in society low ideals both of public and private life.

The saloon is also in other ways an evil element in the social life. It is the tool of petty and unscrupulous polities; it is a power which is sometimes said to control municipal polities; 


\section{THE SALOON AND THE CLUB 225}

and it has a far-reaching effect upon all institutions; upon education, business, and even upon the church.

All these evils are certainly centred about the saloon, and it needs little argument to convict it of most of them. Yet the whole story is $J$ not told until we know what becomes of all these evils when the saloon is abolished.

What elements of good, if any, does the saloon possess? The most frequently heard argument for the saloon is that it is the poor man's club. The claim is made that public opinion about the saloon is based upon the comparatively few cases in which excessive drinking is caused by the saloon, and that it condemns the whole institution unfairly. The workingman, it is said, would have no place of social entertainment, if it were not for the saloon. This is at least an important suggestion. We have been obliged to put great weight upon the socialising influences of alcohol, among all primitive societies. The lower classes of society are essentially primitive. The saloon has a social intention, and to this extent is good. This social character of the saloon has not been sufficiently considered by the most radical anti-saloon party. So important is the socialising of the lower classes, or of all classes, that any institution which can show that it tends to help in this direction is entitled to a respectful hearing. One important 


\section{PSYCHOLOGY OF INTEMPERANCE}

function of social contact, and a free flow of ideas and ideals among all classes of society, is that it creates common knowledge and interests. Ideals of country, home, humanity, of party, and of cause,-all such ideals are produced and sustained only in a freely communicating social flux, of personal contact of man with man. The saloon is certainly the great meeting place of common men; it is a fulcral point where one of the most important impulses of man is brought into activity. It is a live spark. But the saloon, it is true, but pitifully performs its true function. It does not fully socialise. That, however, alcohol has performed a function at just this point, by breaking down barriers, by stimulating ideals and belief, by conveying to the mind standards of social happiness and breadth of emotional life, can scarcely be doubted by anyone who examines the evidence. Alcohol favours the common possession of ideas. The world is a co-ordinated world to a greater extent than it would otherwise be, because of alcohol; and presumably, because of the saloon.

The social function of the saloon can be understood better by comparing it, in all fairness and seriousness, with other institutions that aid in socialising the common man. There is first, of course, the church, to which perhaps one in five is attached. Here various ideals are certainly made common possession. There is also 


\section{THE SALOON AND THE CLUB 227}

the daily newspaper. Through this, opinion is moulded and certain standards of conduct and belief are popularised. Then there is the place of amusement, which, as the recreational life of the people is now carried on, is not yet fully social. The theatre, the concert, is individually enjoyed; but there is little exchange of thought or sentiment. The occupation may be much or little socialising; usually it is the latter. Specialised labour confines a man's thought to a narrow aspect of a large process. The meaning and intention of the whole seldom comes to his mind. His loyalty to his task is slight, and the points of contact with his fellow workers are few. The workingman's union, now undergoing so remarkable a development, is an expression of a long deferred group consciousness for which man has had the motive, but which he has lacked the initiative to produce. On the recreational side, one other important factor has arisen almost from nothing during the past few years. This is the settlement and the social movement among the lowest classes. By this movement, means of contact are greatly increased, and by this and similar movements, for the first time the production of ideals in the lower classes has been brought effectively under direct personal control. Accompanying this idea is now a vast movement, expressed in many forms of which the socialising of the peo- 


\section{PSYCHOLOGY OF INTEMPERANCE}

ple is the purpose. This normal socialising is civilisation experimentally and consciously carried on, and it is one of the great ideas of the age.

Of all the socialising influences of the present time, however, it can be said that the effects of Jalcohol represent a greater attraction than any other force in bringing men together in intimate relations. The saloon is still the avenue through which the great undercurrent of idea and ideal spreads, both the good and the evil. It would be useless to try to estimate how much is good, and how much evil, but the case would not be fairly presented unless, beside the picture of evil which has been drawn, the saloon be placed in its most favourable light, by describing the gain which men under the best conditions of its present organisation may get from it, and contribute through it, to society.

In the first place, the saloon is certainly a (school of rough virtues. In it a man may acquire self-control, may learn standards of conduct, which are at least better than none at all. He acquires certain ideals: of loyalty to party, citizenship and patriotism. The social spirit is fostered in him, correcting the narrow individualism of the home and occupation. Such influences, which keep a man in touch with the common funds of belief and custom, with that undercurrent of thought which never becomes 


\section{THE SALOON AND THE CLUB 229}

in a nation formulated into code or creed, do contribute to the making of national life. The results are drawn upon when national spirit is put to the test, in time of war or public calamity; in times when the co-ordinations of society are severely tested in any crisis. The saloon is a connecting link in the chain of common beliefs, upon which, to a far greater extent than many appear to understand, the welfare of a nation depends. Anyone who has looked into the undercurrents of thought which circulate from one end of the country to the other must have been astonished at the speed with which the unwritten word, the custom, belief, and opinion, the unformulated idea and ideals, spread through these channels of communication. We know that the larger the city the greater is the difficulty of eliminating the saloon. The reason is in part that, in the larger community, the channels of communication and commonising of ideas are more broken, and the part played by the saloon is more important than in the smaller community.

What then is gained, and what is lost by abolishing the saloon? Abolishing the saloon has certainly had the effect of diminishing the number of excessive users of alcohol, has held in check somewhat the lower motives of intoxication, has diminished the economic waste from excessive drinking. The few certainly have 


\section{PSYCHOLOGY OF INTEMPERANCE}

been benefited, in obvious ways. On the other hand, it is easy to over-estimate the good. Withdrawal of the ready-to-hand social element in drinking drives some to more solitary forms of the vice. Many drink quite as excessively as before, and add to their former low motives complicity in the breaking of law. Vices-are interchangeable, and in many, suppression of the habit of drinking increases other vices and abnormalities, no better, but less easily observed. Crime is more or less reduced in amount, especially the minor crimes that result from the instinct of combat.

Abolishing the saloon, speaking for the other side of the case, removes a source of socialisation of the lower classes; takes away a factor in moulding mental force, to which we have been obliged to attach significance. Merely closing the saloon, as a device to hold intemperance in check and to secure the advantages to a community of sobriety, certainly sacrifices one important resource. It takes away the social life of a great number of people, removes the most important factor in the recreational life of the lower classes, or puts it under the ban of the law, and to this extent increases the evils of monotonous specialisation of labour, of narrow routine, sterile emotional life, and narrow outlook.

And yet, in spite of the relative good of the 


\section{THE SALOON AND THE CLUB 231}

saloon, the present writer agrees with what he believes to be the inevitable course of present tendency and public opinion, that the saloon must go. The drinking place, the saloon, in which the interest centres in drinking, is a poor institution compared with that which may be made to take its place, and which is certain in the long run to supersede it. But the factors of good and evil in the present saloon must both be estimated, and we must deliberately put the social life of its patrons upon a better basis.

What can be substituted for the saloon, which shall contain its virtues, and avoid its evils? The problem is still, in part at least, experimental. The method of total abolition of the sale of liquors is or has been decidedly worth trial. It has not been entirely a success, for the reason that it was a radical, narrow, and negative method. The whole problem was not understood. For this problem is nothing less than the organisation of the recreational life of the people. Before this can be done rationally, we must understand what the recreational life is, what it should contain, what it most lacks at the present time.

Daily labour takes up a third of the time of the average man, and another third is occupied in sleep. These two periods of work and sleep, are provided for in a fairly definite and normal way for the majority of people. The free third 
of life is unorganised, is the source of most of the evils and the waste in human life. The average man is in the position of not knowing what to do with his recreational hours. He has no plan of making them count for anything, and he is not able to express an intelligent idea about the meaning of a third of his life, except to say that he uses as much of it as is necessary for certain minor tasks, tries to rest, and have what amusement he can.

The psychology, the physiology, and ethics of recreation constitute a profound and farreaching problem, which cannot of course be treated in detail in a chapter. But at least two functions of recreation may be briefly stated. The first function is to reduce the tension of daily life, and bring the individual down or up to the common level, upon which he can perform with others acts that are restorative, and creative of power and enthusiasm. The second function of recreation is to widen out the individuality of the man; ideally, to bring him into touch with all life interests. Widening and deepening of the individuality, then, is the function of recreation. If it is the purpose of the saloon to be the poor man's club, the chief source of his recreation, it has before it a great and solemn duty to perform. How inadequately it performs it, need not now be said. The positive side of public control of intemper- 


\section{THE SALOON AND THE CLUB 233}

ance, and with it, of many other evils, centres in the organisation of the recreational life, especially of the common people.

What becomes of the saloon in the ideal recreational life? The saloon is a narrow, perverted, and selfish institution, which in its present form is a mere nucleus of what is required. Alcohol at the present time is at least a means of collecting men for the purpose of socialisation. For one, I do not believe the time has come when this drawing power of alcohol can be entirely sacrificed for the sake of a temperance ideal. It is likely that alcohol must still play its part, for a long time to come, in the socialising of the masses, though it may be in a way a minor part. But the idea of the saloon must be broadened, and transformed perhaps beyond recognition, and we may consider the possibilities of the institutional saloon. The institutional saloon must provide for the development and satisfaction of all the normal motives that bring a man to a saloon, and must correct the abnormal motives. In the recreational institution the drinking motive must be merged with others and so be controlled.

The business of manufacture and sale of liquors is a conservative business. It has been able to control and use for its advantage powerful passions of the human mind; and controlling 


\section{PSYCHOLOGY OF INTEMPERANCE}

them, it has been able to control legislation, to crush out competition. The saloon, in which liquor is sold at a large profit, in which the interests of the patron are not considered, is the natural result. To the extent that the liquor traffic can be infused with the spirit of normal business, or forced to adopt it, the saloon problem will in part take care of itself. If this were done, the same organisation of the smaller and poorer into the larger as has taken place in other lines of business would occur, and the saloon would be superseded by the larger, more central institution, in which the interests of the public would be served, in which moral aspects of the use of intoxicants would be considered, and profits reduced by giving to the patron what is now denied him by the saloon,-normal recreational elements. The saloon has evolved but little for lack of normal competition. The drawing power of alcohol and the social needs of the people have been so great that there has been little competition for the recreational interests of the masses. It is likely to remain a line of least resistance. Therefore, it seems, that unless the whole alcohol industry can be reformed, the initiative must come from public sources, or large organised philanthropy. This competition of public and private philanthropy with the saloon, we already see in the recreational movements in the larger cities,-in the 


\section{THE SALOON AND THE CLUB 235}

settlement, the recreational centres and organisations, local libraries, and the like.

In the efforts to combat the saloon by providing public recreation, however, the function of alcohol is not yet fully understood. It may still have a place, and it may for a long time be an important factor in the control of the recreational life of the people. At least this is open to experiment, and can fully be determined only so. The organised recreational institution must compete with the saloon in drawing the public. Competition cannot come from the restaurant, the coffee house, and the temperance saloon. The substitution of non-alcoholic drinks, of tea and coffee and the like, for the alcoholic drink, does not satisfy the psychical motives of drinking. The love of excitement and enthusiasm that keeps the alcohol habit alive, must be transformed, but not suppressed nor ignored.

With the recreational functions of the institutional saloon (since we are speaking of ideals) must be included opportunity for satisfaction of æsthetic interests. Here enter all the possibilities of the dramatic and musical arts, including dancing, in controlling the intoxication motives. But this is not all. There should be provision for two other functions of the ideal recreational institution. There should be educational opportunity, especially in 


\section{PSYCHOLOGY OF INTEMPERANCE}

the form of the more educational pastimes, and provision for the cultivation of interests which lead to avocation. Thus the play motive may be made to lead on to practical results, even to occupational enthusiasms. The great problem of public education, at the present time, is to provide for a continuance of growth and $a$ broadening and development of the enthusiasms among those classes in which there must be early specialisation of labour. It is this raw material of enthusiasm which is so likely to degenerate, or to remain at a low, unproductive plane, and be taken up in low forms of recreation and abnormal habit, that must be directed. To be efficient, power must not only be created, but it must be directed and balanced, and the recreational life more than anything else has for its problem the distribution of interests, and direction of them into proper channels.

Whether or not the present analysis of the intoxication motives and of the recreational life has been correct, the soundness of the standpoint from which the problems have been studied can hardly be questioned. The evils of the saloon are widespread, and they are deepseated in our social life. To try to abolish these evils by mere legislation is a narrow and ineffective means, for we do not thus control the passions that keep these evils alive. No 


\section{THE SALOON AND THE CLUB 237}

single institution will ever be adequate to cope with intemperance. The problem is nothing less than the organisation and direction of the whole recreational life of the people. Wherever men congregate or tend to organise there is presented a practical problem of temperance. The motives thus expressed must be studied, and directed by the philanthropist and educator. These motives cannot be suppressed, nor can motives and forces be created merely to hold them in check. Control must be a natural outgrowth of the desires themselves which are at work producing evils.

Intemperance in the so-called upper classes, and among those who most directly derive their habits from these classes, presents peculiar and difficult practical problems. Especially those who, by reason of wealth and favour, are able to place themselves to a certain extent beyond the reach of laws and the influence of public sentiment and education, are baffling. And yet it is in this tissue of society that some of the worst conditions in a nation take their origin: conditions which favour the development and contagion of disease and degenerative ideas. Unlike. other classes they are but little influenced by progressive ideas taking rise without the class. Their ideals are inbred. They are moved by the changing and shallow motives of 
fashion, and are especially prone to introduce the unwholesome ways of older and degenerate peoples into our midst.

As society is at present constituted, the intemperance of these upper classes is not amenable to control by any measures we can easily command. The true remedy is educational, a remedy which, perhaps, abandons hope for the present adult generation, and seeks to lay a foundation in the next. A method which shall seize upon and mould childhood in its democratic and plastic age is the only remedy for intemperance in the upper classes that will be permanently effectual. The aim must be to make the recreational ideals of the upper classes altruistic and productive-to direct energies into channels which turn toward the improvement of the lower classes. An ideal of public welfare is the best directive force of the unused energies of the idle and privileged members of society. So long as self-improvement and pleasure absorb the energies of the rich we shall not check their intemperance, nor prevent the production of destructive habits that take rise among them. The only radical cure for intemperance in any class is a normal zest of life expressed in productive activity, and thus holding in check and transforming the motives of intemperance that arise from undirected capac- 


\section{THE SALOON AND THE CLUB 239}

\section{ity and power, and from a weariness of life in which there is no deep satisfaction.}

Of many recent studies of the problem of the saloon, two seem especially to have reached fundamental principles. Calkins, in Substitutes for the Saloon, a study made for the Committee of Fifty, concludes that the best means of controlling the evil of the saloon is to take away from the saloon the function of entertainer of the people, and develop the recreational life of the people in every possible way. Various means are mentioned: extension of peoples' clubs already in existence, development of workingmen's clubs (perhaps granting licenses to them), the central recreational institute, municipal night schools, lecture courses, industrial schools, reading rooms, settlements, lyceums, billiard halls, dance halls, the theatre, especially the melodrama, properly conducted pugilism, all athletics, public baths, parks and playgrounds, the peoples' theatre, operas, concerts-all such means are recommended as substitutes for the saloon, satisfying normally the desires which the saloon satisfies abnormally.

The most complete outline of a practical method of substituting normal social life for the unwholesome life of the saloon has been made by Paton, in Counter Attractions to Publio Houses; a plan that has already been worked out in England with good results. The plan is essentially an organisation of the social life of the people, through local social clubs, with a central organisation, using so far as possible schoolhouses and other public properties, and leaving the control mainly in the hands of the people themselves. The aim of the organisation is to bring together in an effective way all the elements of a normal social life for the people. The outline contains provisions also for the extension of the functions of the evening departments of the public schools, and for increased efficiency of the Sunday School organisations. 


\section{CHAPTER XIII}

EDUCATIONAL AND PREVENTIVE MEASURES

THis is a day in which prevention rather than

$\backslash$ cure of social evils dominates our ideals of public welfare. The adult generation is in many ways but little plastic to new ideals, and some classes of society, we have asserted, are quite unchangeable in all their ways, except as they are influenced by the currents of fashion which no one can fully predict or control. It is far easier to teach children how to become good citizens, than to teach adults how to correct themselves. In other words, our best means of controlling all social evils is through those institutions by means of which the ideals of the progressive public come into direct contact with the growing child. The public school, more than any other institution, controls the future; and now, with its improved methods, its widened scope, and with the auxiliary resources of the public playgrounds, the library extension, and other public educational movements, the school is in a better position than ever before for making rapid headway in the building of ideals 
which shall control the abnormal and immoral tendencies in society.

Facts have been brought to light which show clearly what motives produce the evil of intemperance, and which indicate what the danger periods are. The intemperate life is a social product, and its raw material is in great part the undeveloped or perverted growth forces of youth. The great majority of youth of our public schools leave the control of the school and enter occupational life, with very little momentum for completing their mental growth in a normal way. There are no interests strong enough to carry on normal development, the special occupation which they enter upon too often lacks interest; it does not absorb the enthusiasm which is the normal product of the growth forces. Therefore, the enthusiasms remain upon a low plane, they break out in the line of least resistance, seek satisfaction in unproductive and unwholesome social relations, and in various forms of excess. Later these undeveloped desires, these potentialities of happiness that have gone to waste, arise, the ghosts of misspent youth, to lead on to narcotic habits, to indifference, and premature mental old age. The great problem of education at the present time is not so much to fit youth for special work, as to establish interests and habits that will make the individual a complete in- 


\section{PSYCHOLOGY OF INTEMPERANCE}

dividual, and correct the stunting effects of early specialisation in occupation.

What can the public school do to prevent $\times$ these evils? The craving for intoxication, and for stimulants and narcotics, we have had much evidence to prove, is not a specific craving. It is not a craving that can be satisfied by one form of habit alone, but is a plastic force, capable of direction into various channels. The mistake often made in dealing with all the practical problems of temperance is to centre effort upon the narrow and superficial aspect of the impulse that shows itself in the habit of alcoholic intoxication, and to ignore the deeper roots. The function of education is difficult to perform just in proportion as the whole problem is understood, and easy to the extent that teaching 1 is made direct and specific. Education must $-\rightarrow$ prevent the intemperate life by laying a certain foundation for a normal life; and for this there are two main services to be performed. The school must prepare, indirectly at least, for occupational life, both by training in the fundamental co-ordinations of industry, and by establishing those social and moral ideals which alone can make work purposeful, and not merely a mechanical task. There is no occupation, however humble, that may not be made thus wholesome and normal. The second function of the school is to establish habits and 
interests leading to a broader recreational life, in the sense in which we have already used this word. Given a life well started toward a correct balance of interests, in occupation and recreation, the rest can be left to take care of itself. When these fundamental principles of training are understood, one has the clue to all the special resources for training the child in habits and ideals that lead to the temperate life. Whoever thinks that so deep a social habit as drinking can easily be controlled, that the individual may easily be fortified against the allurement of this world-wide passion of drink, is greatly mistaken.

To bring these principles of control to a sharper focus it may be well to point out more specifically the means of fortifying the child against intemperance, most ready to hand in the school. Four main divisions of the work can be made:

1. Specific teaching of facts about alcohol.

2. Moral teaching.

3. Industrial education.

4. Training in recreational interests.

Of all the educational methods of dealing with the liquor problem, the teaching to children of the facts about alcohol, though perhaps of some value if properly done, is the least of all in importance. As commonly taught the facts are repeated year after year, and memorised 


\section{PSYCHOLOGY OF INTEMPERANCE}

without much interest. The mere facts about the use of alcohol, if they are honestly considered, do not by any means point to total abstinence with absolute certainty; and of course this is the lesson that the school is trying to impress. Zeal in impressing the truth of the danger of excess often leads the teacher to distort the facts. The spirit in which this is done is well shown by the remark of a prominent temperance lecturer, with whom I once remonstrated for stating dogmatically conclusions which were decidedly open to doubt, and were at the time being subjected to much scientific discussion and experiment. The lecturer replied, "We shall continue to teach the facts, until science has disproved them." There is a tendency in scientific thought toward the belief that alcohol is in some sense a food; that its permanent deleterious effects upon body and mind, except when used in great excess, are less than was once supposed. At least the picturing to young children of the gross effects of extremely abnormal drinking as typical results (cases in which there is almost always abnormality causing the drinking rather than the reverse) is unwholesome and unxsthetic; and tends to impress wrong ideals of human life, as well as to contradict the facts of science.

For the most part, too, the young and healthy 
person is not much impressed by the picture of dangers to the body from excess. He has an unbounded confidence in the endurance of his own body, and although he may imagine that someone else may be injured, it is difficult for him to believe that he will become a drunkard, or will ruin his health by drinking. Moreover, it is not those who know most about the harmful effects of alcohol who are least likely to be injured by it, and no one knows better its terrors than the drunkard himself.

Teaching of the facts about alcohol should be brief, not extended over all the years of school life, but centred about the early adolescent period. The relation of alcohol to physical strength, to personal appearance and courage, to efficiency and usefulness, should be emphasised rather than its effects upon internal organs. And it is wrong to preach much about total abstinence. Some good biographical material illustrating both the temperate and the intemperate life should be made use of. Overemphasis upon the moral wrong of drinking is vicious, and the sentimental, morbid, and effeminate appeal to refined ideals of perfection is the worst of all. For the teacher to try to impress ideals which the growing boy suspects are due to lack of experience with the world is to lose altogether the power of conveying moral suggestion, and this failure must certainly be avoided 


\section{PSYCHOLOGY OF INTEMPERANCE}

by a teacher. The boy must learn that no sound, strong man drinks to excess; that all men disrespect the hard drinker, and regard his trouble as due to mental weakness or disease. As likely as not such teaching will inspire the boy with a determination never to taste liquor.

As to direct moral teaching in regard to the use of intoxicants little needs to be added to what has been said about the teaching of hygiene. Moral ideals are best imparted to the

child and youth indirectly, by example, by direc$\checkmark$ tion of social activities, by well-chosen advice when most needed, directed to the specific case in hand. Moral principles, and adult ideals of conduct do not influence conduct in proportion to the effort spent in inculcating them. The problem of intemperance has been far too much regarded as individually moral, to the neglect of its other phases; and it has been approached on the practical side far too much by the methods of morality and religion, and too little by the method of indirect control through education. The moral purpose may well be the inspiration of teacher and social worker, but he should keep it in the background, and not make of it his sole method. We do not need so much preaching and teaching to the child, as normal education of those parts of his nature which precede morality, and are the foundations upon which moral behaviour are laid. To produce a 
temperate life, therefore, we must direct our efforts to the co-ordination and direction of all the interests, and not centre attention upon a single sentiment, nor even upon the moral life as a whole.

Intemperance is but a type and single expression of a fault of mental and physical development. Whatever retards or perverts the development of an individual, and prevents the harmonious balance of his functions favors wrong habits of all kinds; and whatever makes for normal and full development makes for temperance. Given a sound heredity, and normal opportunity for the development of the instincts and interests, with proper direction of the social activities during the formative years, and the individual may be allowed to take care of his own morals in after life. Whether he drinks moderately or not at all will be of comparatively little consequence, and will be determined largely, and perhaps rightly, by the ideals of the society in which he lives. At least the question of total abstinence is not now the most important consideration.

The indirect education for the temperate life is the most important, and the most difficult; it is as yet, we may say, the ideal rather than the practice of the public school. Industrial teaching is the first to consider. In the past, and to a great extent now, the public school has 


\section{PSYCHOLOGY OF INTEMPERANCE}

failed to connect with the working life of the man. It has given him information, but no lasting interests. When he enters upon his trade he does so with no deep roots of educated interest. In the industrial idea is the means of overcoming this evil. Training, in school, in the foundations of industry serves to connect occupation with play, and to bring to it interests which are otherwise not co-ordinated with practical activities. Industrial training affords opportunity, too, for normal socialising of individuals, as the older methods of the school have not. The child sees his activities as part of a whole, becomes an individual by becoming a link in a chain, and so grows to understand the purposes and ideals of society. He comes to his life work not only with actual preparation, but with interests co-ordinated in such a way that the work may draw upon deep enthusiasms which would otherwise go to waste.

In another respect the education of the present stands at the verge of a new ideal. In the past the recreational or play life of the child has been entirely undirected by the school, and all its force has been lost. Now not only is the play spirit of the child being brought into the work of teaching, but the play life is being extended and directed at many points. It is seen that if the child grows by play, it is possible to continue his growth after he has left school, by 
the momentum of his play interests. The school in the past has rarely succeeded in imparting to the child any interest which he maintains after he leaves school. Unless there is immediate use for it in occupation, the boy seldom continues his school work, but lays it entirely aside, and turns to new interests. The present ideal is to make play not only a means of motor training, of establishing interests in active sports, which will help to keep the enthusiasms normal while progressive, but to make it the basis of permanent intellectual and social interests. By taking away much of the dull routine of school work, and making school life more active, more social, and more pleasant, and connecting its interests in many ways with recreational interests outside the school, a means is provided for extending the normal interests of the individual to maturity, whether he remains in school or leaves and goes to work. This must be the greatest function of the school, to develop interests which will persist into adult life, and carry growth to completion. In this work the school must be aided by other institutions which will take the child when he leaves the school, and will connect with the interests he has formed there. All such movements as those described in the last chapter are efficient aids of the public school, in directing the recreational interests 
of those who, though having completed school, are still in their most active growing periods, and still in the greatest need of public control. The strengthening of individuality, the acquirement of broader life experience, is what must be attained, and it can be attained only in a wholesome social environment. The later stages of growth, like the earlier, are certain to take on the character of the social environment in which they are passed, and unless the social environment can be controlled, no amount of preparation of the individual by his school life can be entirely successful. Therefore, we repeat, so to educate the child that he will continue to grow in all his functions after. he leaves school and enters upon occupation is the most important work of the school; and to expand our system of education so that it shall provide for the later stages of growth is the greatest public need of the day. It is certain that to provide the right recreational life for the people is quite as necessary a part of public education as anything that is done in the school.

In another respect the modern school is making progress toward the elimination of the excessive drinker and other defectives from society. There is at least a good beginning of a science of individuals, one of the most important practical services of which is the detection, 
in the early stages, of cases of defective moral, mental, and physical organisation. Its problem takes into account also the factors of environment, and effort is being made to diagnose the whole situation of unpromising individuals, with a view to controlling their future.

Much more could and should be done in the public schools in the study of individuals in order to detect in the making the drunkard and other criminal, vicious, or defective types and conditions. Those who are suspected of weakness or abnormality, and those whose conditions of life are bad, should be individually studied, and enough of their history and progress recorded to form conclusions about the direction of their tendencies and the best means of controlling them. We have at present almost no reliable knowledge about the early stages of most of the abnormalities, and we must look in great measure to the school for it. Each fresh discovery of a great criminal, each new instance of an apparently well-conditioned man going to ruin because of alcoholism, excites our wonder. Our next door neighbour or old school companion commits a crime, or becomes insane, or a drunkard, and then we recall how eccentric he was as a child, or how unfortunate his surroundings. But he went through the schools, and no one detected abnormal tendencies. He 


\section{PSYCHOLOGY OF INTEMPERANCE}

was treated like all the rest, and took his chance in the mass. The school should at least mark for study the unusual case, and collect information which can be used later. 


\section{CHAPTER XIV}

CARE, CURE, AND CONTROL OF THE DRUNKARD

From the facts and laws already presented the main principles of the care, control, and cure of the abnormal case can readily be inferred. Between drunkenness and moderate drinking there is no fixed line, and what has been said about the control of social drinking applies, when especially adapted, to the drunkard.

Two kinds of excessive users of alcohol must be distinguished from one another. The abnormal dipsomaniac or periodical drinker is a diseased person, and he requires the attention of the specialist in nervous disorders. Such cases are to be treated by all the hygienic and remedial measures now known to the practice of neurology. They require both physical and mental hygiene, education in mental control, suggestive and other psychotherapeutic treatment. There is no specific cure for drunkenness, and from its very nature there cannot be. Moral and religious motives certainly are a powerful aid to the medical methods, and cure of drunkenness made by conversion or other religious or moral methods is sound and in accord- 


\section{PSYCHOLOGY OF INTEMPERANCE}

ance with the principles of psychology. Profound changes in the moral life, such as are produced by conversion, are alterative of all the mental and social habits, and the periodicity of a nervous disorder is often broken up by these means. Whatever convinces a man that he will drink no more is certain to facilitate the cure, whereas the belief that the craving for alcohol is rooted in the structure of the body helps to keep up the suggestions which lead to a breakdown of the will. Many cases in which there are pronounced abnormalities of body or mind, or signs of nervous disorder of any kind, although the drinking may not be periodic, and perhaps not greatly excessive, also require medical advice and treatment. Confinement in penal institutions for all such inebriates is worse than useless, for there conditions are usually both mentally and physically unhygienic.

The common drunkard, the man who drinks, as a rule, whenever he has opportunity, is a somewhat different problem. His drinking is almost entirely social, and whether he shall drink or stay sober is determined by his environment. He has little if any craving for alcohol as such, but his difficulty lies largely in his undeveloped nature, his narrow individuality, and entire lack of inner sources of growth and interest. He has little moral re- 


\section{CARE OF THE DRUNKARD}

sistance, even if he has ideals, and it is useless to ask him to stay sober, when he is in the midst of drinking company.

From this class most of the chronic drunkards who fill our jails and almshouses are recruited. As a rule they are not vicious, and they differ from thousands of respectable, but mild and purposeless, members of society mainly in the social environment and the habits of life, into contact with which they have been thrown by birth or circumstances. Detention does not cure these people, and they have no pronounced disease of the nervous system yet recognised which needs treatment. They are not in the least changed for the better by a term of confinement. It is the social surrounding and social habit that is at fault, and in the entirely unsocial life of the jail they learn nothing and acquire no new social habits. Instead of acquiring control thus, the will deteriorates. They yield to whatever vices can be induiged in within the walls of prison, and leave worse, or no better, than when they came. Some assert that the regularity and routine of prison life teach regularity of habits, but such training is like some of the class work in school, it fails to connect with the natural life, and leaves no impression. No method of treatment that does not have in view to change radically the social habits of a man, can go far towards effecting 


\section{PSYCHOLOGY OF INTEMPERANCE}

a cure for drunkenness. Prison life we say can make no radical change in a man's habits. He emerges from it, as from a long slumber, to take

J up life just where he left it. Our houses of correction do not usually deserve the title, for they do not correct. They do not even punish effectively, for life in them is so empty of content, whether of pleasure or pain, that while it seems long in passing, it appears short in retrospect, and lacks the sharp, clear emotional qualities a punishment must have, if it is to be deterrent of misdemeanours. That detention is not deterrent of drunkenness, the history of any hundred men who have been committed abundantly shows. Most return again and again, some voluntarily; and the county jail is to a greater extent than many know the winter resort of the tramp element who find outdoor life in the cold season unpleasant.

How incompetent the drunkard is to construct from within his cell an escape from his vices, is well illustrated by one of my own cases. A somewhat prepossessing young man who had already been committed several times for drunkenness, was asked what he thought his prospects for the future were, whether he would be likely to drink again. He said that he should never drink another drop. He had no taste for liquor, anyway, and it was only when he was with drinking companions that he 
drank at all. When asked about his acquaintances he said they were all drinking men, some moderate, some heavy drinkers. In fact he knew no other social life than that of the saloon. He was then asked whether he thought he would be able to go back among his associates and stay sober, or perhaps drink moderately. That he said at once would be impossible.

"What will you do then?" I asked him. "How will you spend your time when you are not at work?" He thought a minute, and replied,

"Well, I am not going to go with the fellows any more."

"Where will you go?"

"I will go off to walk by myself in the evening."

One may imagine how long such a resolution would be effective, and yet such a plan is a fair example of the drunkard's power of self-direction. Apparently this young man had given no thought till he was asked, about the ways and means of reform. He had vaguely come to the conclusion that he would never drink again, but that such a radical change in his life would require more than a simple decision seems not to have occurred to him, although it is likely that he had made the same resolution many times before, and failed to keep it. Of course it is futile to expect the drunkard to reform himself. 
It is the work of others to furnish the resources of control for the drunkard, and teach him how to develop inner strength.

When it is recognised that the work of reform of the drunkard must be radically educational (re-educational, for the man must be educated over again as from childhood), a clue to the method of treatment will be obtained. Generally speaking it is a long process, to "reform" a drunkard, with need of skilful treatment at every point. He needs usually physical upbuilding. He needs in many cases to learn a trade, some new occupation in which the conditions for self-control will be better than in his old life. He needs moral ideals, and recreational interests. All these he usually lacks both from want of initiative to get them for himself, and from lack of sufficient suggestion from environment.

When a man is legally detained, to a certain extent his future is under control. Now is the time to bring to bear upon him all possible educative influences, so as to leave him at the end of his term faced toward a normal social life. The industrial farm seems the best of all reformative situations for the drunkard. ${ }^{*} \mathrm{He}$ needs to get back to fundamentals; to learn to

* The Farmfield Reformatory for Inebriate Women at Horley, England, with its cottage system and home and garden work seems to offer almost ideal conditions for the class it treats. 
dig out his living, to be situated where work may be to some extent co-operative and social, the very opposite of that which is found in the jail where every man is doing the same thing individually. Most of these offenders are easy to control, from the very fact that they lack self-direction. Terms should be indeterminate, and there should be authority to direct the occupational life and to release on trial. We can teach the defective and undeveloped man to live a normal life, only by placing him in the midst of one, and this should be the basic principle of the treatment of the form of inebriety of which we are speaking. Some cases, probably most, need permanent direction and control.

Something further should perhaps be added about the religious cures of drunkenness. Facts gathered at the McAuley Mission and at other missions in New York City leave no doubt in the mind of the writer that conversion, under the conditions in which the missions are able to accomplish it, is a powerful means of controlling drunkenness. Many men come to these missions drunk, and pass through some kind of an experience which frees them from their habits of drink. Some of these cases, it must be said, however, are very morbid, and their cures seem rather a change in the form of their disease than a real cure. They become intemperately religious and moral, and show 


\section{PSYCHOLOGY OF INTEMPERANCE}

signs of their weakness of mind and character in everything they do. Many too are at the time of life when sudden cessation of the habit of intoxication is likely to occur, or when the power of the habit is declining.

Whatever supernatural factor may be present in conversion, and this need not be discussed at this point, the cure is made permanent by changing the social habits of the man. He casts off his associations with men who drink, and forms a new social life for himself among those who do not drink. When this new life has taken sufficient hold of his interests, and his new behaviour has strong enough social reinforcement, he may then be safe in the midst of much temptation, and is likely not to revert to his old ways. This is the desired end of all methods of treating inebriety. Change the social habitat and the habit is largely controlled. A serious limitation of much of the excellent work of the churches is that they have no organised means of creating a new social habitat for their convert. They can command a little of his time on Sunday, an hour in the mid-week perhaps, and an occasional evening, but the church does not reach out as it should into the actual life of the man. Just to the extent that the church can affect the social and recreational life will its power to control such evils as drunkenness be increased. 


\section{CHAPTER XV}

SUMMARY OF PRACTICAL PRINCIPLES

THE practical principles of the control of intemperance which have been suggested can now be gathered up briefly in a few conclusions. It is always true of every great social problem, from the very complexity of the factors which produce the condition, that no single principle can be laid down which shall serve as a guide to the practical solution of it. The problem of intemperance involves broad questions of human evolution; intemperance is a product of impulses which lie at the very bottom of human progress. The practical questions of control must ultimately be studied from many scientific points of view-from the medical, psychological, social, and ethical-and then the conclusions must be adapted to concrete situations in which problems of expediency and local conditions must also be taken into consideration. There can be no hard and fast rule of procedure deduced from science, for the solution of a social problem. Often too much is expected of science. All it can do is to bring its report of facts and interpretations of them, and suggest what, 


\section{PSYCHOLOGY OF INTEMPERANCE}

various conditions being assumed or ignored, should be done to produce a given result, with perhaps a higher degree of probability. It may suggest that the method must be one of trial and error, or it may point out with confidence some one line of action better than all the rest. There is always much more to be learned and the scientific point of view is never complete. In the meantime, action must take place, and the scientific conclusions will have greater or less weight according to the complexity of the problem. We must understand that the control of intemperance must still be in a large measure experimental. We must try various methods, and any broadly conce: ved plan of action, made reasonably probable of success after all the evidence that can be brought to bear upon it has been sifted, is worthy of trial. Practical common sense, scientific insight, and an openminded experimental attitude toward the problem will together produce the best results.

It is possible that the scientific evidence might warrant the conclusion that the best method of curing intemperance is to abolish the manufacture and sale of alcohol. Considering the question purely from the physiological side, this might fairly be deduced from the facts. Psychological evidence, as has been explained, casts doubt upon the wisdom of this, and a study of the intoxication motive makes it rea- 


\section{SUMMARY OF PRINCIPLES}

sonably certain that this result cannot be attained. The intoxication impulse often controls the very legislation which would be necessary to abolish alcohol, and would even over-. ride the law. Yet the misery and poverty which is certainly inflicted upon many innocent victims by alcohol, would seem on superficial view to warrant the concentration of effort upon the legislative problem. But this remains still experimental. We do not know what legislation can be secured, or precisely what its effect will be until it is tried. Trial of local and state prohibition of alcohol has certainly not been remarkably successful. Drinking is a symptom of deep forces and to treat merely the symptom, as we do by legislation, does not seem enough. The study of the saloon shows that it exists because to a certain extent it fulfils a normal need of man. This need must be recognised and met in the treatment of intemperance. The way in which that may most naturally be done has been pointed out. The problem is that of working out in a practical way a social hygiene,- physical, mental, and moral,-a method of controlling the recreational life of the people, and providing for the expression of all normal motives. This hygiene must extend into the occupational life, and rightly conceived, the problem is one of conscious evolution. The work is positive, and not merely negative. We 


\section{PSYCHOLOGY OF INTEMPERANCE}

must discover what the factors of evolution are, what the factors of degeneration are, and put them more completely under control. This is not a mere generalisation and an abstract theory, but is rather a justification of what is already the trend of the best public effort. All institutions, the church, the school, the recreational institute, must be made to extend outward their influences, each from its own centre, into the social life of the people in a definite, planned manner, and control the motives which lead to the intemperate and inefficient life. This is striking at the root and not at the flower of the evil. Whether or not alcohol shall still play a part in this scheme may be left an open question. In a certain sense it is a minor matter. Life may be temperate with or without alcohol-and it may be intemperate also under either of these conditions. This is not an argument against prohibition. But it is emphatically an argument against the belief that when legislation is secured that prohibits the sale of alcohol, the effort of social reform may cease. It is now needed more than before. The situation must still be regarded as experimental; there is no permanent, accomplished achievement. Too often the cause of temperance is at a standstill the day after the no-license vote has been secured. Positive effort in communities in which the license system prevails is now more 
important than to secure more local legislation. It is in the large city, where local legislation cannot be secured, that the best work must be done. It seems as though all must admit that eventually temperance in the presence of alcohol is better than temperance where alcohol cannot be obtained. It is inner control through organised interests that is the ideal of an education of the individual, and the same ideal must be maintained in the education of society. It is temperance through inner control that we must work toward if we wish to live in moral freedom, and not in a stage of development in which a large part of the energy of one group must be expended in controlling the actions of another, thus using two sources of energy with a wholly unproductive result. Control must often be a temporary expedient, but it is a makeshift, not an ideal and final procedure. The normal development of society, as of the individual, is from outer to inner control, and any mode of treating. a social problem which does not produce progress toward this end, is shortsighted if not totally mistaken.

These are the reasons why the problem of intemperance is educational rather than legislative. The broadest and deepest work must be done in the school, in prevention, in forming habits which will control in adult years all those impulses and desires which are the source of all 


\section{PSYCHOLOGY OF INTEMPERANCE}

the social evils. The best indications of progress toward temperance, therefore, are found not in the results of the fall elections, but in the appropriations of local governments for the schools, in the introduction of industrial methods in education, and the provision for playgrounds and other organised modes of controlling the recreational life of the people.

The same principles must be applied to the treatment of the excessive user of alcohol. The root of his trouble is in an abnormal social life, and an unbalanced or undeveloped complex of interests. Cure for the most part must be the outcome of organisation of his interests, and the reconstruction of his social habits. The drunkard must be re-educated, in other words. His habits must be broken down, and reassembled on a higher plane, and only when this is done can he be said to be cured. We shall sometime look back upon the treatment of the drunkard and other delinquents, which prevails at the present time, as a relic of barbarism and primitive ignorance in the midst of civilisation. What for example could be more completely wrong than to try to cure the drunkard by punishment and isolation, when his greatest need is a normal social life? It is not to be wondered at that our officials who administer justice almost invariably believe the drunkard incurable. 


\section{REFERENCES}

1. Jellyfish, Starfish, and Sea Urchins. P. 227.

2. W. H. Kesteven. A Note on the So-called Stimulating Effect of Alcohol on Protoplasm. Quart. Jour. of Ineb. Vol. $30,3$.

3. The Descent of Man. P. 7.

4. Morgan, Habit and Instinct.

5. Morgan. Op. cit.

6. Music and Dancing in Nature.

7. Play of Animals.

8. Early Man in Britain and His Place in the Tertiary Period. P. 293.

9. Mescal Buttons. Medical Record, 1896. Vol. I, pp. 258-266.

10. Social History of the Races of Mankind. Vol. IV, p. 249.

11. Ethics. Vol. I, p. 441.

12. Featherman. Op. cit., Vol. II, p. 499.

13. The Folk-Lore of Plants. P. 103.

14. Featherman. Op. cit., Vol. III, p. 128.

15. Featherman. Op. cit., Vol. III, p. 161.

16. Featherman. Op. cit., Vol. IV, p. 459.

17. Featherman. Op. cit., Vol. IV, p. 459.

18. Primitive Industry. P. 315.

19. Featherman. Op. cit., Vol. III, p. 170.

20. Featherman. Op. cit., Vol. II, p. 115.

21. Featherman. Op. cit., Vol. III, p. 164.

22. Featherman. Op. cit., Vol. III, p. 550.

23. Featherman. Op. cit., Vol. II, p. 350 .

24. Bancroft. Native Races. Vol. I, p. 550.

25. Bancroft. Op. cit., Vol. I, p. 551.

26. Bancroft. Op. cit., Vol. I, p. 706. 
27. Featherman. Op. cit., Vol. IV, p. 115.

28. Andaman Islanders. P. 44.

29. Featherman. Op. cit., Vol. III, p. 341.

30. Customs Among the Natives of East Africa, Journal of the Anthropological Institute, 1891, p. 367.

31. Hall. Adolescence.

32. Havelock Ellis. Affirmations.

33. Eleusinian and Bacchic Mysteries.

34. Greek Lyric Poetry. P. 102.

35. Critical History of the Language and Literature of Ancient Greece. Vol. III, p. 88.

36. Ellis. Affirmations.

37. The Civilisation of the Period of the Renaissance. Vol. I, p. 181.

38. Civilisation During the Middle Ages. P. 365 .

39. Op. cit., Vol. II, pp. 246-7.

40. Renaissance in Italy. Vol. I, p. 411.

41. Leuba. National Destruction and Construction in France as seen in Modern Literature and in the Neo-Christian Movement. American Journal of Psychology, July, 1893, Vol. V, No. 4, p. 498 .

42. Geddes and Thomson. The Evolution of Sex. Pp. 18, 270 .

43. Man and Woman. P. 2.

44. Evolution of General Ideas. P. 76.

45. The Quatrains of Omar Khayyam. Introduction.

46. Anstie. Stimulants and Narcotics.

47. Stimulants and Narcotics. One may consult also on these points standard works on materia medica and therapeutics, such as Wood, Brunton, etc.; also standard works on poisons.

48. W. S. Hall. Jour. of Ineb. Vol. XXXIII, 2.

49. J. G. Null. Jour. of Ineb. Vol. XXXII, 1.

50. For the evidence for classing alcohol among the foods see Alcohol, by J. Starke.

51. W. S. Hall. Jour. of Ineb. Vol. XXX, 4.

52. The Liquor Problem. Published for the Committee of Fifty.

53. For a good review of the most important experimental 


\section{REFERENCES}

studies of the effects of small doses of alcohol consult M. A. and A. J. Rosanoff's Evidence Against Alcohol.

54. For a complete report of these experiments see American Journal of Psychology. Vol. XI.

55. Evidence Against Alcohol. M. A. and A. J. Rosanoff.

56. Summarised from reports of sixty cases gathered from the literature of the subject.

57. Psychology of the Emotions. P. 424.

58. Jour. of Ineb. Vol. XXXI, 2.

59. G. R. Wilson. Clinical Studies in Vice and Insanity.

60. Leuba. A Study in the Psychology of Religious Phenomena. American Journal of Psychology, April, 1896, Vol. VII, No. 3, pp. 309-383.

61. Alcohol Inebriety, 1883.

62. From Thomann's Real and Imaginary Effects of Intemperance.

63. In correspondence.

64. In correspondence.

65. In correspondence.

66. Degeneration.

67. Quart. Jour. of Ineb.

68. Alcohol. The Sanction for Its Use.

69-71. Quart. Jour. of Ineb.

72. Popular Science Monthly, 1879, Supplement. N. S. I, p. 30 .

73. Quart. Jour. of Ineb.

74. Stimulants and Narcotics.

75. The Present Evolution of Man. 



\section{INDEX}

Abandonment, craving for, Baboons, intoxication in, 15. 37 ; in intoxication, 104.

Abnormal cases, 133-; relation to normal, 6,9 .

Adams, 48.

Adding, 122.

Adolescence, intoxication motives in, 56, 204; love of excitement in, 41.

Adrenal system, 130.

Alcohol, and ideals, 226; as excretion, 86; as food, 87 ; as socialising influence, 228 ; effects of large quantities, 88; effect upon oxidation, 88; experimental study of effects, 89-, 101-; future of, 264 .

America, intemperance in, 54 . American Indians, 36. Analytic methods, 83.

Animals, psychology of, 12; excitement in, 17; intoxication in, 11-, 201; sexual excitement in, 18.

Anstie, 84.

Arion, 46.

Aristotle and Plato, doctrine of soul, 80.

Associations, experiments upon, 105-, 109-.

Bacchic and Eleusinian mysteries, 45.

Bancroft, 36.

Beard, 175-.

Black drink, 32 .

Braintwaite, 160.

Burckhardt, 48.

Calkins, 239.

Carnivals in Venice, 48.

Chapman, 17.

Child, excitement in, 40 .

China, 42.

Church, social aspects of, 226.

Civilized nations, drinking in, $42,206$.

Classification of drunkards, 133, 210.

Committee of Fifty, 56.

Control of intemperance, 5 .

Conversion, 152, 259.

Craving for alcohol, 135-, 165-, 211.

Crothers, 159, 161.

Creeks, 30, 33.

Dancing, 38.

Danielewski, 169.

Darien Indians, 29.

Darwin, 15. 
Dawkins, 25.

Day, 169.

Death and intoxication, 30.

Delabarre, 100.

Destrée, 91.

Developmental periods and intaxication, 47.

Dionysus, 26, 205; worship of, 44.

Dipsomania, 150.

Dogs, intoxication in, 14-.

Drinking habits, age when ac quired, 157-.

Drugs, experiments with, 100.

Drunkards, care of, 221 ; confinement of, 255 ; control of, 253-; social life of, 255-.

Dyaks, 34.

Dyer, 29.

Education for temperance, 220 -

Educational measures, 240-.

Ellis, 58.

Emotional changes in intoxication, 120.

Estimation of time, 122.

Experiments upon sarsia, 13.

Farnell, 46.

Featherman, 27, 30, 36 .

First drink, 157.

Forel, 172.

French-Sheldon, Mrs. 39.

Fuegians, 35.

Genetic methods, 22.

Glooscap, 32.
Gonds, 35.

Greece, 43.

Greek, art, 46; dithyrambic poetry, 76.

Groos, 18.

Guatamalans, 34.

Habits and motives, 200; explanation of, 19-

Hadley, 160.

Hens, intoxication in, 14.

Higher classes, intemperance in, 238.

Hindus, 26.

Hodge, 15.

Hudson, 18.

Hunt, 88.

Huysmans, 54.

Indeterminate sentence, 259 .

Individual, and race, 207; study of, 250.

Indra, 25.

Industrial, education, 247-; farm, 258.

Inheritance, 184-; of habits, 173.

Intemperance, and evolution, 195; and legislation, 236; and warlike spirit, 50.

Intoxicants, and narcotics, 82 ; universality of, 35 ; origin of, 23.

Intoxication, abandonment in, 131 ; excitement in, 45 ; and literature, 79; and language, 72; and growth, 203-; and religion, 24; 
emotional changes in, 120-; experimental case of, 108; in higher classes, 237; in savage and child, 40; motives and development, 61-; and instinct, 66 ; among civilized peoples, 50; in Greek poetry, 76; in literature, 71; physiology of, 120, 126-; varied uses of, in primitive society, 29.

Intoxication impulse, methods of studying, 7 ; problem of, 3, 5, 6; theories of, 164-.

Kava ceremony, 33.

Keeley Cure, 156.

Keres, 34.

Kesteven, 13.

Khayyam, 77-.

Kiawa Indians, mescal ceremony of, 26.

Kräpelin, 89, 96.

Kuertz, 91.

Language and intoxication, 72.

Lapps, 30.

Legislation and intemperance, 236.

Lett, 166.

Liquor business, 233-.

Literature and intoxication, 79.

Lombard, 95.
Man, E. H., 35.

Marriage and intoxication, 30 . Mayer, 91.

Mental cures, 152-.

Mental processes, effects of alcohol upon, 96.

Mensius, 42.

Mescal ceremony, 26-.

Monin, 174.

Moral, attitudes, 4 ; teaching, 243-.

Mosquitos, 34.

Mosso, 52.

Movement, experiments upon, 122.

Moxon, 174.

Mure, 46.

Muscular power, effects of alcohol upon, 80-; experiments upon, 102.

Myth and wine, 72.

Napoleonic wars, excitement after, 53.

Narcotic motive, 51, 55, 161, 206, 212.

Narcotics in eastern countries, 43.

Neolithic man, 25.

Nerrous system, effects of drugs upon, 85.

Neurotic conditions and religious excitement, 24 .

Nietzsche, 44, 45, 52 .

Nirvana, 51, 71.

Nordau, 166.

Occupation, 227, 231. 
Paget, 68.

Parrish, 157.

Paton, 239.

Periodic drinking among savages, 33.

Personality sense in intoxication, 131.

Philippines, natives of, 28.

Physical treatment, 170-

Physiology, and pathology, teaching of, 245; of alcohol, 86-; of intoxication, 127.

Physiological, basis of intoxication motive, 67; view, limitation of, 68-.

Practical principles, 261-; problems, 219-.

Prairie chickens, excitement among, 17.

Prentiss and Morgan, 27, 100.

Primitive peoples, drinking among, 22-, 61, 202.

Prohibition, 230, 262.

Psycho-analysis, 151.

Pueblos, 27, 34.

Pulse rate, in intoxication, 124.

Public school and intemperance, 241-.

Reaction time, 89.

Recreation, 232; and intemperance, 248; and the saloon, 233; institute of, 235 . Reid, 177-, 192.

Reflex action, 123; experiments upon, 103.
Religion, and intoxication, 24 ; excitement in, 24.

Renaissance, intemperance in, 48; immorality in, 49.

Renan, 72.

Rhythms in activity, 59.

Ribot, 128.

Romanes, 13.

Rosanoff, 98.

Saloon, 220, 222; evils of, 223; normal features of, 225 ; social aspects of, 226 ; substitutes for, 231.

Sajous, 130.

Samuelson, 42.

Saxon races, intemperance in, $32,49$.

Schneider, 91.

Scientific attitude, 8.

Seminoles, 32.

Sex differences in intemperance, 58.

Sexual excitement, 38; and intoxication, 44; among animals, 18; relation of to intoxication, 20.

Sin and alcohol, 164; and intemperance, 9 .

Shamanism, 27-.

Shooking and Sheeking, 43.

Slang and intoxication, 72.

Social, excitement, 135-; hygiene, 263; life and intoxication, 64, 266.

Soma worship, 26.

Spencer, 27, 36.

Starke, 87, 128, 166. 


\section{INDEX}

State of intoxication, 100.

Stimulants and narcotics,

84-; effects of, 208-.

Stimulus, doctrine of in medicine, 80.

Strenuous life and narcotics, 55.

Symonds, 49.

Synonyms for intoxication, 73-.

Taylor, 45.

Temperance, 36, 214.

Theories, of intoxication, 164, 212-.

Thomann, 168.

Tobacco, use of by American Indians, 32; craving for, 149.

Tuscaroras, 30.
Urabas, 31.

Wabanaki, 32.

War dance, 38.

War physic, 33.

Wasps, 14.

Weir-Mitchell, 100.

Williams, 134.

Wilson, 134.

Wit in intoxication, 106.

Woodcock, excitement in, 17.

Worth, 17.

Writing and adding, effects of alcohol upon, 96.

Yakuts, 27.

Yeast plant, 86.

Zend Avesta, 26. 



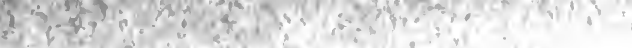

\section{.}




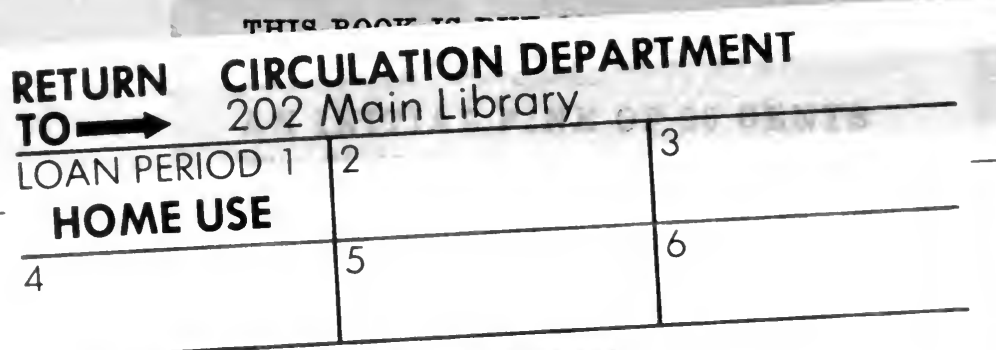

ALL BOOKS MAY BE RECALLED AFTER 7 DAYS

1. month loans may be renewed by calling 642.3405

6. month loans may be recharged by bringing books to Circulation Desk

Renewals and recharges may be made 4 days prior to due date

\section{DUE AS STAMPED BELOW}

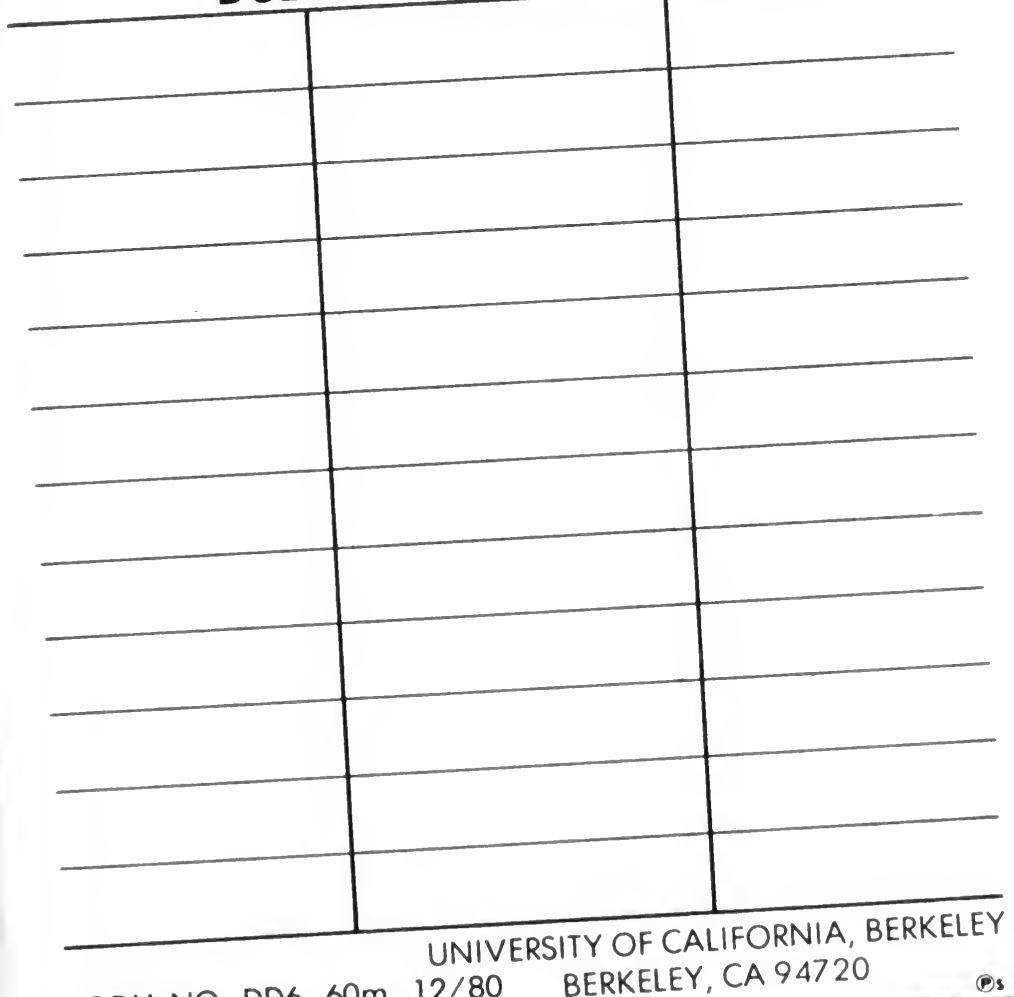

FORM NO. DD6, 60m, 12/80 BERKELEY, CA 94720 


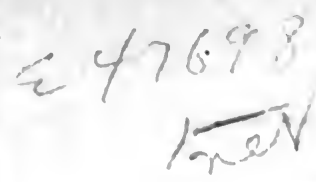

U.C. BERKELEY LIBRARIES

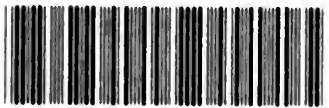

c03597386b

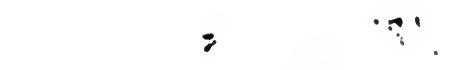

is

HV 352719

$\mathrm{P}_{3}$

Pantidage 
